UNIVERSIDADE DE SÃO PAULO

ESCOLA DE ENFERMAGEM

MARCOS MORAIS SANTOS SILVA

Condicionantes da adesão à profilaxia pós-exposição de risco ao HIV em um serviço de saúde no município de São Paulo, Brasil

SÃO PAULO

2020 


\section{Condicionantes da adesão à profilaxia pós-exposição de risco ao HIV em um serviço de saúde no município de São Paulo, Brasil}

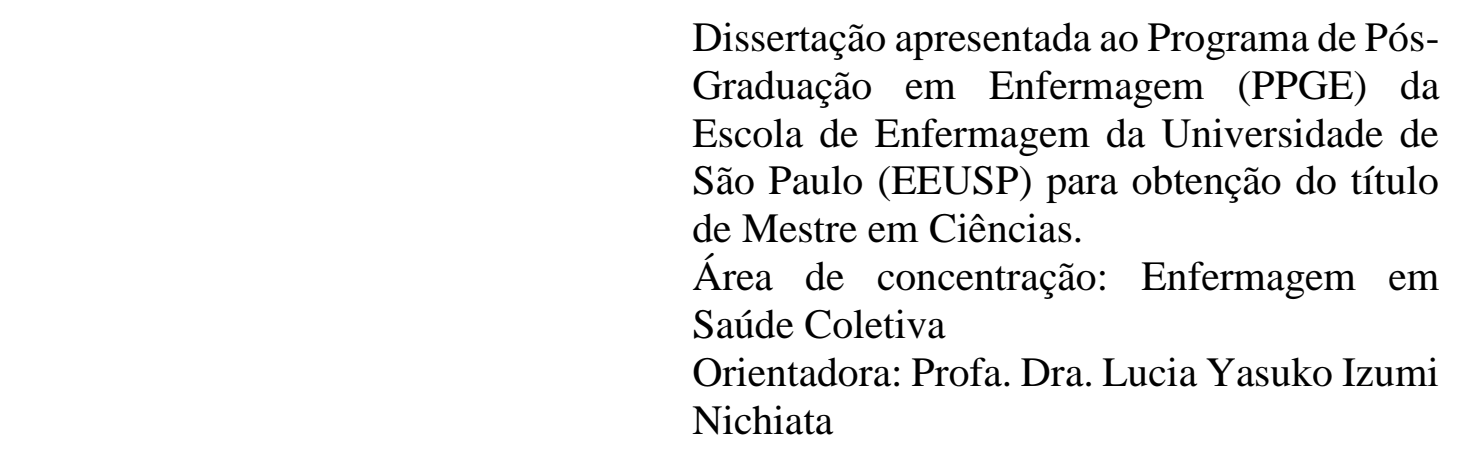

Versão corrigida

(Original encontra-se disponível na biblioteca "Wanda de Aguiar Horta")

São Paulo 
AUTORIZO A REPRODUÇÃO E DIVULGAÇÃO TOTAL OU PARCIAL DESTE TRABALHO, POR QUALQUER MEIO CONVENCIONAL OU ELETRÔNICO, PARA FINS DE ESTUDO E PESQUISA, DESDE QUE CITADA A FONTE.

Assinatura:

Data:

\section{Catalogação na Publicação (CIP)}

Biblioteca "Wanda de Aguiar Horta"

Escola de Enfermagem da Universidade de São Paulo

Silva, Marcos Morais Santos

Condicionantes da adesão à profilaxia pós-exposição de risco ao HIV em um serviço de saúde no município de São Paulo, Brasil / Marcos Morais Santos Silva. São Paulo, 2020.

$143 \mathrm{p}$.

Dissertação (Mestrado) - Escola de Enfermagem da Universidade de São Paulo.

Orientadora: Profa. Dra. Lucia Yasuko Izumi Nichiata Área de concentracão: Enfermagem em Ciências

Ficha catalográfica elaborada por Fabiana Gulin Longhi (CRB-8: 7257) 
Nome: Marcos Morais Santos Silva

Título: Condicionantes da adesão à profilaxia pós-exposição de risco ao HIV em um serviço de saúde no município de São Paulo, Brasil

Dissertação ao Programa de Pós-Graduação em Enfermagem (PPGE) da Escola de Enfermagem da Universidade de São Paulo (EEUSP) para obtenção do título de Mestre em Ciências.

Aprovado em:

\section{Banca Examinadora}

Orientador: Profa. Dra.

Instituição:

Assinatura:

Prof. Dr. Instituição:

Julgamento: Assinatura:

Prof. Dr. Instituição:

Julgamento: Assinatura:

Prof. Dr. Instituição:

Julgamento: Assinatura: 


\section{AGRADECIMENTOS}

A Deus, por tudo que proporcionou em minha vida.

A minha querida orientadora Profa. Dra. Lucia Yasuko Izumi Nichiata, pela paciência, pela inspiração e pelos ensinamentos desde a graduação e por acreditar que eu era capaz. Sua participação foi essencial para a construção deste trabalho. Não posso deixar de mencionar sua humildade e sua empatia. Obrigado!

Aos meus pais, Maria e Dalvino, verdadeiros heróis, que dedicaram suas vidas para minha educação e formação como pessoa.

Aos meus irmãos, Elenilson, Elielma, Eleniles e Wesley, pela ajuda em diversos aspectos da vida, principalmente nos momentos mais difíceis.

À minha companheira Kelly, pela compreensão e pelo apoio durante esse processo.

Aos amigos da moradia estudantil Paulo, Thiago, Rafael e Lucas, que foram pessoas essenciais, parceiros e irmãos.

Ao grande amigo Nacib, por todo o apoio e pela amizade.

Aos amigos Ivan, Edvaldo e Henrique, que trabalharam comigo anteriormente ao meu ingresso na universidade, por sempre acreditarem no meu sonho.

À amiga Nathália Simão, companheira do grupo de pesquisa, pela ajuda em todas as etapas do processo.

À amiga Natália Veiga, pela ajuda e pela força.

À amiga Luciane, pelas orientações e pela ajuda no exame de qualificação e nas análises de dados. Suas contribuições foram essenciais.

Aos amigos e amigas do departamento, por compartilharem angústias na sala dos bolsistas.

Às especialistas do departamento, pelo carinho e pelas orientações.

A todos os orientandos da Profa. Dra. Lucia, pela troca de experiências e pelo apoio.

A todas as professoras do Departamento de Saúde Coletiva, pelo apoio e pelo incentivo. 
À coordenadoria municipal de saúde e a todos os funcionários do SAE em que realizei a coleta de dados.

Ao Conselho Nacional de Desenvolvimento Científico e Tecnológico (CNPq), pelo suporte financeiro a este trabalho através da concessão de bolsa de mestrado para o desenvolvimento da pesquisa.

Agradeço a todos vocês! 
Tem que acreditar. Desde cedo a mãe da gente fala assim: "Filho, por você ser preto, você tem que ser duas vezes melhor". Aí passado alguns anos eu pensei: como fazer duas vezes melhor, se você tá pelo menos cem vezes atrasado pela escravidão, pela história, pelo preconceito, pelos traumas, pelas psicoses... por tudo que aconteceu? Duas vezes melhor como? Racionais MC's - A vida é desafio 
Silva MSS. Condicionantes da adesão à profilaxia pós-exposição de risco ao HIV em um serviço de saúde no município de São Paulo, Brasil [dissertação]. São Paulo: Escola de Enfermagem, Universidade de São Paulo; 2020.

\section{RESUMO}

Introdução: A profilaxia pós-exposição de risco ao HIV é uma das diretrizes internacionais recomendadas como medida de prevenção contra o HIV. Estudos, embora escassos, particularmente no Brasil, mostram baixa adesão à profilaxia, especialmente nos casos de exposição sexual. Objetivo: Analisar a adesão à PEP de risco ao HIV devido à exposição sexual em usuários de um serviço de atenção em HIV/Aids do município de São Paulo, selecionados de 1 o de abril a 30 de agosto, com seguimento até 23 de outubro de 2019. Método: Estudo de abordagem quantitativa, descritivo e analítico, tipo coorte prospectivo realizado em um serviço de atenção especializada em HIV/Aids da Secretaria Municipal de Saúde de São Paulo, localizado na região central. A população do estudo foi composta por homens e mulheres, maiores de 18 anos, entrevistados e acompanhados durante um ciclo da profilaxia: $1^{a}$ consulta (baseline) e dois retornos subsequentes - 30 dias (momento 1) e 90 dias (momento 2), no período de 1 o de abril a 23 de outubro de 2019. Foi aplicado um questionário estruturado com questões divididas em: características socioeconômicas; modo de viver; modo de trabalhar; processo de saúde; e atendimento do serviço de saúde. No caso de usuários que não retornaram à consulta, foi realizado contato telefônico para realização da entrevista e verificação dos motivos para o não retorno ao serviço. Critério de adesão: uso de 27 dias de antirretrovirais e retorno em pelo menos um dos dois momentos. Foi realizada análise descritiva, apresentando números absolutos e relativos e análise bivariada com os testes estatísticos qui-quadrado ou Exato de Fisher para condicionantes associados a adesão à profilaxia. Os dados foram compilados no Excel e analisados no software STATA versão 15. Resultados: Entrevistou-se 91 usuários, com média de idade de 32,5 anos, maioria do sexo masculino $(86,8 \%)$, homens que fazem sexo com homens $(62,2 \%)$, da cor branca $(49,5 \%)$ e com ensino superior ou pós-graduação $(65,9 \%)$. Aderentes à profilaxia foram $56,7 \%$, e apenas $6(6,6 \%)$ retornaram nos dois momentos. Não houve soroconversão para HIV entre os $41(45,0 \%)$ usuários que retornaram para realizar o teste rápido. A única variável associada à adesão foi a condição "não ter plano de saúde" $(\mathrm{p}<0,05)$. Outras variáveis não demonstraram significância estatística $(\mathrm{p}<0,2)$. Como condicionantes que favoreceram a adesão: início precoce da profilaxia, informação sobre a profilaxia fornecida pela equipe de saúde e presença de crença religiosa; e como condicionantes que desfavoreceram a adesão: ocupação que exige certa qualificação, acesso a benefícios advindos do trabalho formal, renda insuficiente para cuidados de saúde, participação em grupo associativo ligado ao trabalho, à Igreja e ao voluntariado, e sentimento expresso para desistência quanto à tomada do antirretroviral. Conclusões: A adesão à profilaxia ao HIV de usuários de um serviço de saúde do município de São Paulo é alta em relação ao uso dos antirretrovirais, considerando os critérios estabelecidos no estudo, e, no entanto, baixa em relação aos retornos. É preciso ampliar a divulgação e a captação de outros segmentos da população que possivelmente não estão acessando a profilaxia, como mulheres, pessoas com condições precarizadas na vida e no trabalho, adolescentes e população em situação de rua.

Palavras-chave: Profilaxia pós-exposição. Adesão à medicação. Vulnerabilidade. HIV. Enfermagem. 
Silva MSS. Conditions of adherence to post-exposure prophylaxis for HIV risk in a specialized care service in the city of São Paulo, Brazil [master thesis]. São Paulo: School of Nursing, University of São Paulo; 2020.

\begin{abstract}
Introduction: The post-exposure prophylaxis for HIV risk is one of the international guidelines recommended as a preventive measure against the HIV epidemic. Studies, although scarce, particularly in Brazil, show low adherence to prophylaxis, especially in cases of sexual exposure. Objective: Analyze the adhesion to the post-exposure prophylaxis from risk for the infection by the HIV due to consented sexual exposure in users of an attention service in HIV/Aids in the city of São Paulo, selected from April 1st to August 30th, with follow-up until October 23th, 2019. Methods: A quantitative, descriptive and analytical study, a prospective cohort study carried out in a specialized HIV/Aids care service at the São Paulo Municipal Health Secretariat, located in the central region. The study population consisted of men and women, over 18 years old, interviewed and followed up during a prophylaxis cycle: 1st appointment (baseline) and the two subsequent visits - 30 days (moment 1) and 90 days (moment 2). A structured questionnaire wasapplied with questions divided into: socioeconomic characteristics; way of living; way of working; health process; and health service attendance. In the case of the users who missed any of the returns and with who the telephone contact was successful, the interview was conducted by telephone call, trying to figure out the reasons for the lack of return. Standard for adherence: use of antiretrovirals for 27 days and return in at least one of the two moments. A descriptive analysis was performed, presenting absolute and relative numbers and bivariate analysis with the chi-square or Fisher's Exact statistical tests to explore possible conditions associated with adherence to prophylaxis. The data were compiled in Excel and analyzed using the STATA version 15 software. Results: 91 users were interviewed, with an average age of 32.5 years old, mostly male $(86.8 \%)$, men who have sex with men $(62.2 \%)$, white $(49.5 \%)$, and with higher education or postgraduate education $(65.9 \%)$. Adherents to prophylaxis were $56.7 \%$, and only $6(6.6 \%)$ returned at both times. There was no seroconversion to HIV among the 41 (45.0\%) users who returned to accomplish serology. The only variable associated with adherence was the condition of "not having health insurance" $(p<0.05)$. Other variables did not show statistical significance $(\mathrm{p}<0.2)$. Conditions that damaged adherence: early start of prophylaxis, information on prophylaxis provided by the health team and presence of religious beliefs; and conditions that that damaged adherence: occupation that requires a certain qualification; access benefits that come from formal work, insufficient income for health; participation in an associative group linked to work, church and volunteering, and an express feeling of withdrawal regarding taking antiretroviral drugs. Conclusions: the adherence to the prophylaxis against HIV of users of a health service in the city of São Paulo is high regarding the use of antiretrovirals, considering the standard stablished in the study, however low regarding the returns. The user profiles were concentrated in white and schooled people. It is necessary to expand the dissemination and capture of other segments of the population that are possibly not accessing prophylaxis, e.g., women, people with precarious conditions in life and work, adolescents and homeless people.
\end{abstract}

Keywords: Post-exposure prophylaxis. Adherence to medication. Vulnerability. HIV. Nursing. 


\section{LISTA DE FIGURAS}

Figura 1. Distritos administrativos com maior taxa de detecção de Aids por 100 mil habitantes - município de São Paulo - 2014. 23

Figura 2. Taxa de detecção, por 100 mil habitantes, de infecção pelo HIV notificada em pessoas com 15 anos de idade ou mais, de acordo com a faixa etária e o sexo - município de São Paulo - 2009 e 2018. .24

Figura 3. Mandala de prevenção combinada. .25

Figura 4. Fluxograma de seleção dos artigos, de acordo com as bases bibliográficas utilizadas - São Paulo - 2018 29

Figura 5. Coordenadorias de Saúde do município de São Paulo - 2019. .56

Figura 6. Período das entrevistas em relação ao acompanhamento do usuário no baseline, no momento 1 e no momento 2 . 62

Figura 7. Panorama geral do estudo no baseline, no momento 1 e no momento 2 em relação ao contato, ao retorno, ao uso do medicamento e à adesão. 


\section{LISTA DE QUADROS}

Quadro 1. Bases de dados, descritores e palavras-chave usados na estratégia de busca para revisão da literatura. São Paulo, 2020. 28

Quadro 2. Distribuição dos estudos encontrados na revisão, segundo país de publicação, autor, ano, desenho do estudo, tamanho da amostra e informações sobre a adesão, seus condicionantes, presença de efeitos adversos e soroconversão. São Paulo, 2020................31 Quadro 3. Distribuição dos serviços de saúde que oferecem a PEP ao HIV no município de São Paulo. São Paulo, 2018. 57

Quadro 4. Distribuição das questões que foram aplicadas na baseline, no momento 1 e no momento 2 . 60

Quadro 5. Descrição das variáveis independentes. 64 


\section{LISTA DE TABELAS}

Tabela 1. Adesão à PEP devido à exposição sexual ao HIV segundo as variáveis medicamento e, ao menos, um retorno no momento 1 ou no momento 2. São Paulo, 2019.

Tabela 2. Caracterização dos usuários segundo as variáveis sociodemográfica no baseline. São Paulo, 2019. .71

Tabela 3. Caracterização dos 20 usuários que iniciaram a PrEP ou uma nova PEP segundo variáveis sociodemográficas no baseline. São Paulo, 2019.

Tabela 4. Caracterização dos usuários segundo variáveis de formas de trabalhar no baseline. São Paulo, 2019. 74

Tabela 5. Caracterização dos usuários segundo variáveis de formas de viver no baseline. São Paulo, 2019. .75

Tabela 6. Caracterização dos usuários segundo variáveis do processo de saúde no baseline. São Paulo, 2019. .78

Tabela 7. Conhecimento sobre a transmissão e as consequências do HIV. São Paulo, 2019.

Tabela 8. Caracterização dos usuários segundo variáveis do serviço de saúde no baseline. São Paulo, 2019. .80

Tabela 9. Caracterização dos usuários segundo variáveis do processo saúde e doença no momento 1. São Paulo, 2019. .82

Tabela 10. Caracterização dos usuários sobre variáveis do processo de saúde no baseline, no momento 1 e no momento 2, segundo os retornos. São Paulo, 2019.

Tabela 11. Caracterização dos usuários sobre variáveis do serviço de saúde no baseline, no momento 1 e no momento 2, segundo os retornos. São Paulo, 2019.

Tabela 12. Comparação das variáveis sociodemográficas associadas com a adesão à PEP. São Paulo, 2019. .89

Tabela 13. Comparação das variáveis de formas de trabalhar associadas com a adesão à PEP. São Paulo, 2019.

Tabela 14. Comparação das variáveis de formas de viver associadas com a adesão à PEP. São Paulo, 2019.

Tabela 15. Distribuição dos usuários de acordo com as variáveis do processo de saúde-doença e correlação com a adesão. São Paulo, 2019. 
Tabela 16. Distribuição dos usuários de acordo com as variáveis do serviço de saúde e correlação com a adesão. São Paulo, 2019. 


\section{LISTA DE SIGLAS}

3TC

Aids

AMA

ARV

BVS

CDC

CEAT-VIH

CEP

$\mathrm{CR}$

CRS

CRT

CTA

DP

DTG

EEUSP

EUA

HAART

HIV

HPV

$\mathrm{HSH}$

IST

ONU

OPAS

PA

PCDT

PEP

PIS

PrEP

PS

SAE

lamivudina

síndrome da imunodeficiência adquirida

Assistência Médica Ambulatorial

antirretrovirais

Biblioteca Virtual em Saúde

Center for Disease Control and Prevention

Cuestionario para la evaluación de la adhesión al tratamiento

antirretroviral

Comitê de Ética em Pesquisa

Centro de Referência

Coordenadoria de Saúde

Centro de Referência e Tratamento

Centros de Testagem e Aconselhamento

desvio-padrão

dolutegravir

Escola de Enfermagem da Universidade de São Paulo

Estados Unidos da América

Terapia Antirretroviral Altamente Ativa

vírus da imunodeficiência humana

papilomavírus humano

homens que fazem sexo com homens

infecções sexualmente transmissíveis

Organização das Nações Unidas

Organização Pan-Americana da Saúde

pronto atendimento

protocolo clínico e diretrizes terapêuticas

profilaxia pós-exposição

Programa de Integração Social

profilaxia pré-exposição

pronto-socorro

serviços de atenção especializada 
SI-DST

SUS

TARV

TCLE

TD

TDF

TDF/FTC

UNIFESP

UPA

UNAIDS
Aids-módulo de diagnóstico sorológico

Sistema Único de Saúde

terapia antirretroviral

termo de consentimento livre e esclarecido

taxa de detecção

tenofovir

tenofovir e entricitabina

Universidade Federal de São Paulo

Unidade de Pronto Atendimento

United Nations Programme on HIV/Aids 


\section{SUMÁRIO}

APRESENTAÇÃ

1 INTRODUÇÃ

1.1 Panorama de distribuição do HIV e aids no mundo e no Brasil ................................20

1.2 Prevenção combinada e em destaque a profilaxia pós-exposição de risco ao HIV ....25

1.3 Adesão à profilaxia pós-exposição de risco ao HIV: revisão da literatura ..................28

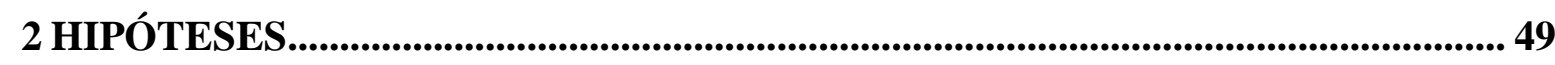

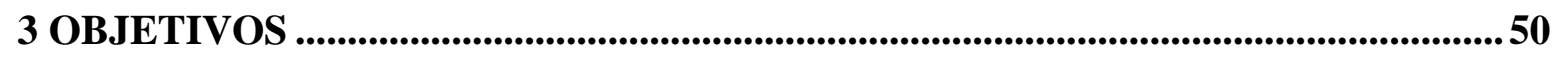

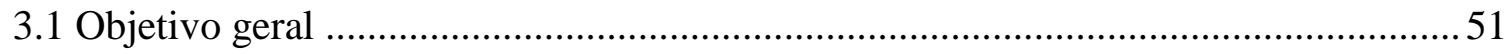

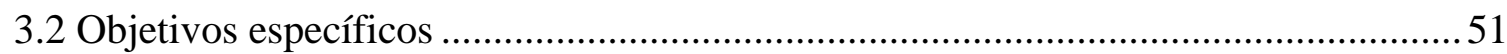

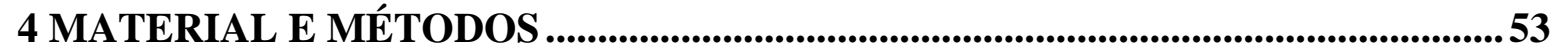

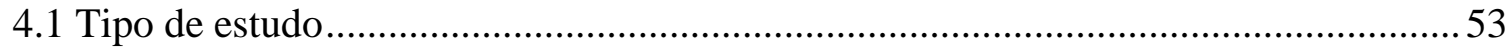

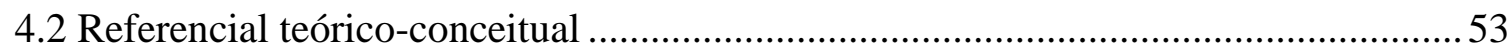

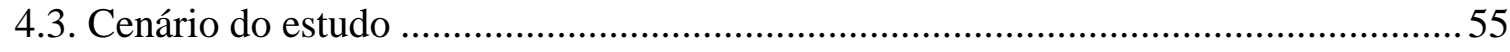

4.4. População do estudo e critérios de inclusão e exclusão.............................................59

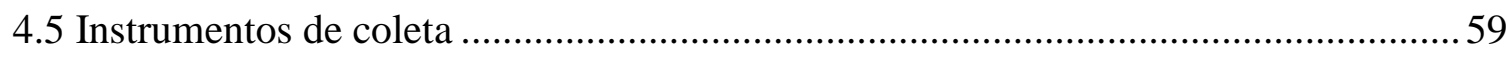

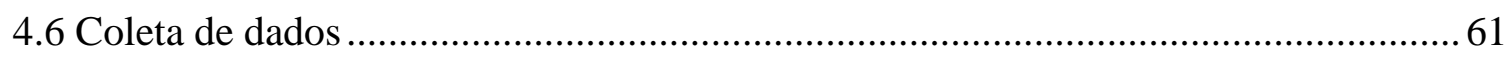

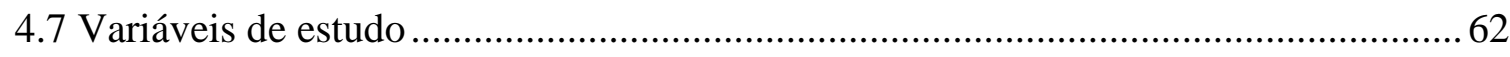

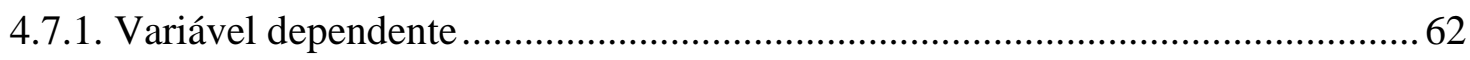

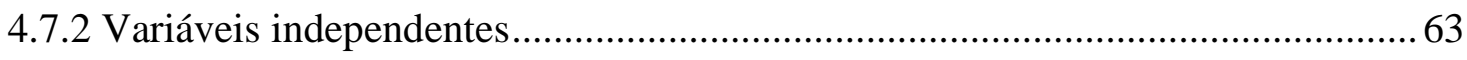

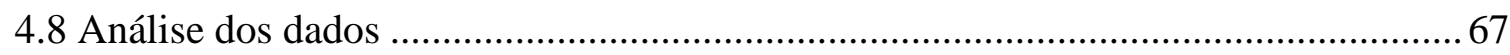

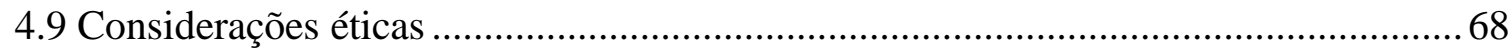

5 RESULTADOS

5.1 Panorama do estudo no baseline, no momento 1 e no momento 2 .............................70

5.2 Caracterização sociodemográfica, as formas de trabalhar e viver ............................. 71

5.3 Processo de saúde, conhecimento sobre a transmissão e consequências do HIV ........76

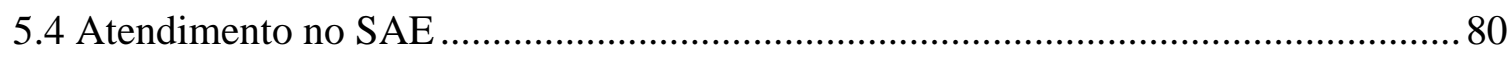


5.5 Retornos dos usuários indicados à PEP - 30 dias e 90 dias

5.6 Adesão a PEP por exposição sexual ao HIV em um SAE HIV/aids ........................... 89

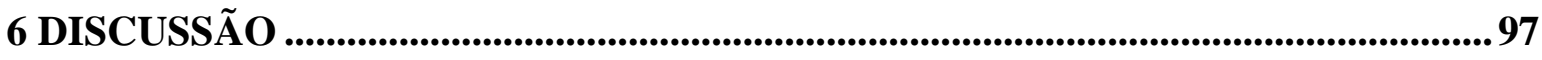

7 CONCLUSÃ

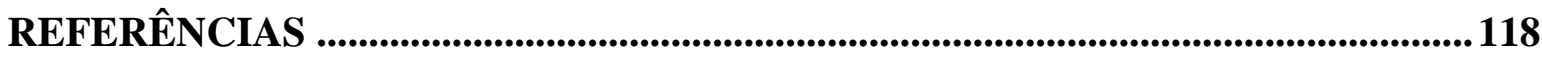

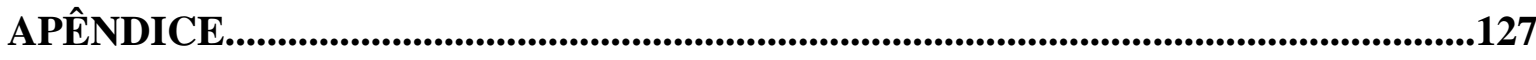

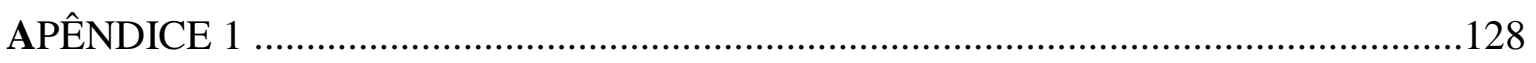

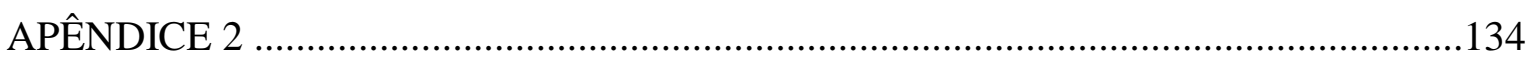

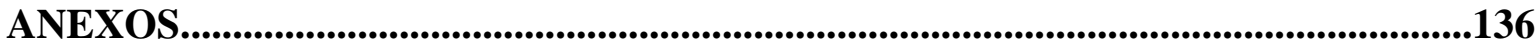

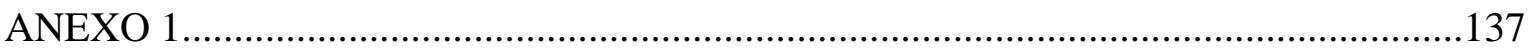

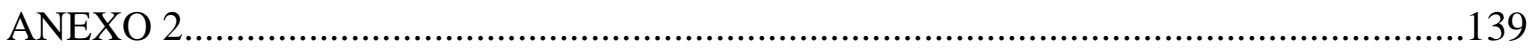

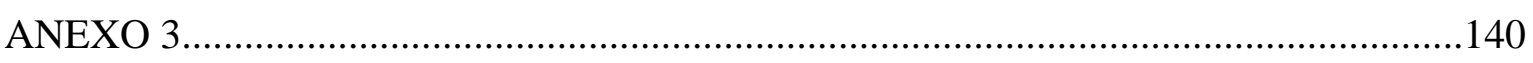

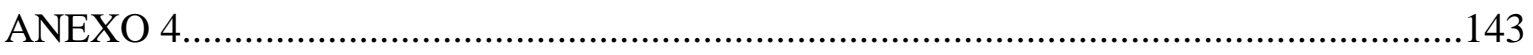




\section{APRESENTAÇÃO}

Meu primeiro contato com a pesquisa foi durante o segundo ano da graduação na Escola de Enfermagem da Universidade de São Paulo (EEUSP - 2015), ano em que fui convidado a participar do grupo de pesquisa intitulado “Avaliação de necessidades", sob coordenação da Profa. Dra. Maria Amélia Campos de Oliveira. Ademais, desenvolvi trabalhos com o Prof. Dr. Divani Vargas sobre o tema "Consumo de álcool em estudantes universitários", quando fui bolsista pelo CNPq.

Após essas duas experiências, conheci a Profa. Dra. Lucia Yasuko Yzumi Nichiata, orientadora do presente estudo, que me convidou para participar do grupo de pesquisa "Adesão, necessidades e vulnerabilidade em saúde coletiva", grupo que integro até os dias atuais. Assim, começamos a desenvolver trabalhos na temática do vírus da imunodeficiência humana e da síndrome da imunodeficiência adquirida (HIV/Aids), mais precisamente voltados para a adesão à profilaxia pós-exposição (PEP) de risco ao $\mathrm{HIV}$, apresentados na modalidade pôster; ao Hepatoaids, em 2016, na modalidade oral curta; durante o $12^{\circ}$ Congresso Brasileiro de Saúde Coletiva, em 2018, no Rio de Janeiro; e em um congresso internacional, na modalidade pôster, com o título "Implementação da linguagem padronizada (NANDA-NIC-NOC): proposta de um instrumento de registro de primeira consulta de enfermagem com pessoas que buscam profilaxia pós-exposição ao HIV (PEP)", na Universidade de Santander, na Colômbia, em 2017.

A partir disso, iniciamos uma iniciação científica, durante a qual fui bolsista Fapesp da pesquisa intitulada "Fatores que interferem na profilaxia pós-exposição ao HIV", estudo que também foi apresentado como trabalho de conclusão de curso (TCC) em 2017.

Após essas experiências e certos aprendizados, decidi que poderia seguir com a pesquisa e com a temática da adesão à PEP de risco ao HIV. Dessa maneira, participei do processo seletivo para o mestrado acadêmico da EEUSP e, uma vez aprovado, em 2018, iniciei a pesquisa do presente estudo.

Nesse sentido, o presente trabalho busca entender quais os condicionantes que podem interferir na adesão à profilaxia, a depender de características socioeconômicas, do modo de trabalhar, do modo de viver e do processo de saúde dos usuários de um serviço de atenção especializada em HIV/Aids, e também do atendimento oferecido por esse serviço. 


\section{INTRODUÇÃO}

O objeto do presente estudo é a adesão à profilaxia pós-exposição (PEP) de risco ao vírus da imunodeficiência humana (HIV) pelos usuários de serviços de saúde, após uma possível exposição sexual ao HIV. Questiona-se: como ocorre a adesão entre usuários atendidos em um serviço de saúde do município de São Paulo? A princípio, será apresentado o panorama de distribuição do HIV e da síndrome da imunodeficiência adquirida (aids) no mundo e no Brasil, seguido pelas ações de prevenção voltadas à redução de novos casos, com destaque à PEP, terminando com a revisão da literatura sobre a adesão à PEP.

\subsection{PANORAMA DE DISTRIBUIÇÃO DO HIV E DA AIDS NO MUNDO E NO BRASIL}

No início da década de 1980, ocorreram os primeiros casos da Aids nos Estados Unidos da América (EUA). Jovens homossexuais apresentaram uma disfunção da imunidade celular, decorrente de uma pneumonia causada por Pneumocystis carinii e do sarcoma de Kaposi, com evolução rápida levando a óbito. Nessa mesma década, casos semelhantes foram descritos em outras regiões do mundo, espalhando-se rapidamente entre os continentes e afetando milhares de pessoas. Sem se saber como controlar essa nova doença, sua disseminação aconteceu em pouco tempo, atingindo caráter pandêmico ainda na década de 80, com uma estimativa de 3,4 milhões de novas infecções em todo o mundo (Wainberg, 2008).

Em 1983, Luc Montagnier descreveu o retrovírus causador da aids. Um ano depois vieram outras provas, por meio da demonstração do crescimento viral, relatado pelo Dr. Robert Gallo nos EUA (Barré-Sinoussi et al., 1983; Gallo, 1984). O HIV é responsável pela aids; sua transmissão ocorre a partir de fluidos corporais, como sangue, e ataca o sistema imunológico, comprometendo os linfócitos TCD4+. A destruição das células TCD4+ causa enfraquecimento do sistema imunológico e, consequentemente, deixa a pessoa exposta a doenças oportunistas, como a pneumonia, agravando a aids (Brasil, 2017a).

Ao se descobrir o agente causador da aids, as investigações para prevenção e controle foram intensificadas. Em 1995, foi aprovado o primeiro inibidor de protease, iniciando uma nova era da terapia antirretroviral altamente ativa (HAART) e poupando cerca de 2,5 milhões de mortes pelo acesso ao medicamento. A fim de padronizar o uso da HAART, em 1998, o 
Centro de Controle e Prevenção (CDC) emitiu as primeiras diretrizes para adultos vivendo com HIV nos EUA, abrindo espaço para que outros países pudessem se espelhar no foco ao tratamento e à prevenção da infecção (Centers for Disease Control, 1995; Mann 1992).

O início da HAART configurou um grande passo no controle do HIV/aids: em 2008, a incidência da doença mostrou-se 30\% menor em comparação aos anos entre 1980 e 90 nos EUA. Apesar da redução, esse quadro indicava a necessidade de intensificar as ações de prevenção para reduzir ainda mais os novos casos de infecção pelo HIV (Wainberg, 2008).

No mundo, desde o início da epidemia até 2018, aproximadamente 74,9 milhões de pessoas foram infectadas pelo HIV e 32 milhões de pessoas morreram por complicações relacionadas à aids. Em 2018, 37,9 milhões de pessoas viviam com HIV, e, desse total, 8,1 milhões (21\%) desconheciam seu estado sorológico. Dos 29,9 milhões (79\%) que tinham conhecimento de seu estado sorológico, apenas 23,5 milhões (62\%) tiveram acesso ao tratamento (UNAIDS, 2020a). Nesse mesmo ano, 770 mil pessoas foram a óbito em decorrência da aids (UNAIDS, 2020a). Ao se comparar esse índice com o pico de 1,7 milhão de mortes em 2004, houve uma redução de 55\% - porém, as ações de prevenção e tratamento precisam ser intensificadas a fim de diminuir ainda mais esses dados (UNAIDS, 2020b)

O HIV/aids continua sendo um grande problema de saúde pública, e sua distribuição é desigual nas diferentes regiões do mundo. Há predomínio de pessoas vivendo com HIV em países de baixa e média rendas, principalmente no continente africano. Na África Oriental e Austral, há cerca de 20,6 milhões de pessoas vivendo com HIV; somente em 2018, houve 800 mil novas infecções pelo vírus e mais de 300 mil óbitos motivados pela aids (UNAIDS, 2020b).

Na América Latina e no Caribe, de acordo com a Organização Pan-Americana da Saúde (Opas), em 2018 havia mais de 2,1 milhões de pessoas vivendo com HIV, e 1,6 milhão (76\%) sabia que tinha o vírus. O conhecimento do estado sorológico, juntamente ao acesso à terapia antirretroviral (TARV) e aos métodos preventivos, promoveu uma redução de 12\% nas mortes causadas pela aids na América Latina e de $23 \%$ no Caribe, no período compreendido entre 2010 e 2017 (OPAS, 2018).

Porém, apesar do progresso, a taxa de novas infecções ainda permanece em 100 mil casos por ano na América Latina, com redução de apenas $1 \%$ quando comparada à de 2010. O teste para HIV representa um elemento importante para diagnóstico e tratamento da doença, pois cerca de um terço das pessoas só descobre a infecção ao apresentar sinal e sintomas da aids, na qual há comprometimento importante da imunidade, indicando exposição ao vírus e possível transmissão da doença a outras pessoas (Opas, 2018). 
Em 2018, no Brasil, foram detectados 966.058 casos de aids, com uma taxa de detecção (TD) de 17,8/100 mil habitantes. Houve uma queda na TD, passando de 21,4/100 mil habitantes em 2012 para 17,8/100 mil habitantes em 2018, com um decréscimo de 16,8\%. Essa redução se intensificou a partir de 2013, pois nesse ano foi implementada a proposta do "tratamento para todos", que consiste na expansão do uso de antirretrovirais para os seguintes casos: linfócitos CD4 abaixo de 500 células $/ \mathrm{mm}^{3}$; relacionamento sorodiscordante (quando um dos parceiros está infectado pelo HIV e o outro, não); coinfecção com a hepatite B; problemas renais e/ou cardíacos; e a inclusão de medicamentos, como o tipranavir e o maraviroque (Brasil, 2019, Brasil, 2018d).

Do total de casos de aids, entre 1980 até 2019, há concentração nas regiões Sudeste e Sul do país e corresponde a 51,3\% e 19,9\%, respectivamente. Nas outras regiões, as taxas são menores, com $16,1 \%$ na região Nordeste, $6,6 \%$ na região Norte e $6,1 \%$ na região CentroOeste. A média dos casos por ano, em relação à TD da aids entre 2014 e 2018, na região Sul e Sudeste foi de 7,7 mil e 15,4 mil, respectivamente, 4,4 mil na região Norte, 8,9 na região Nordeste e 2,8 mil na região Centro-Oeste (Brasil, 2019).

A região Sudeste é destaque nos casos de infecção pelo HIV, especificamente o município de São Paulo, do estado de São Paulo, que registrou o primeiro caso de aids no Brasil, em 1980, e desde então tem tido notoriedade no número de novos casos, nas ações de prevenção e tratamento das pessoas vivendo com HIV (São Paulo, 2012). O presente estudo foi desenvolvido nesse município e destaca aspectos importantes sobre a infecção pelo HIV.

No município de São Paulo, entre 1980 e junho de 2018, foram diagnosticados 99.905 mil casos de aids sendo a maioria do sexo masculino (73\%) (São Paulo, 2019). Em 2015, a razão era de dois homens para uma mulher, mas ela aumentou para 4:1 em 2018 (São Paulo, 2019). Em 2014, a região central passou a ser aquela com a maior TD de aids do município: Centro (112/100 mil habitantes), Norte (39/100 mil habitantes) e Sudeste (35,5/100 mil habitantes). Os bairros que possuem as maiores TD de aids são: República, Brás e Sé. Considerando a República, região onde foi realizado o estudo, há TD de 132,4/100 mil habitantes, conforme a Figura 1 (São Paulo, 2015). 
Figura 1. Distritos administrativos com maior taxa de detecção de aids por 100 mil habitantes - município de São Paulo - 2014.

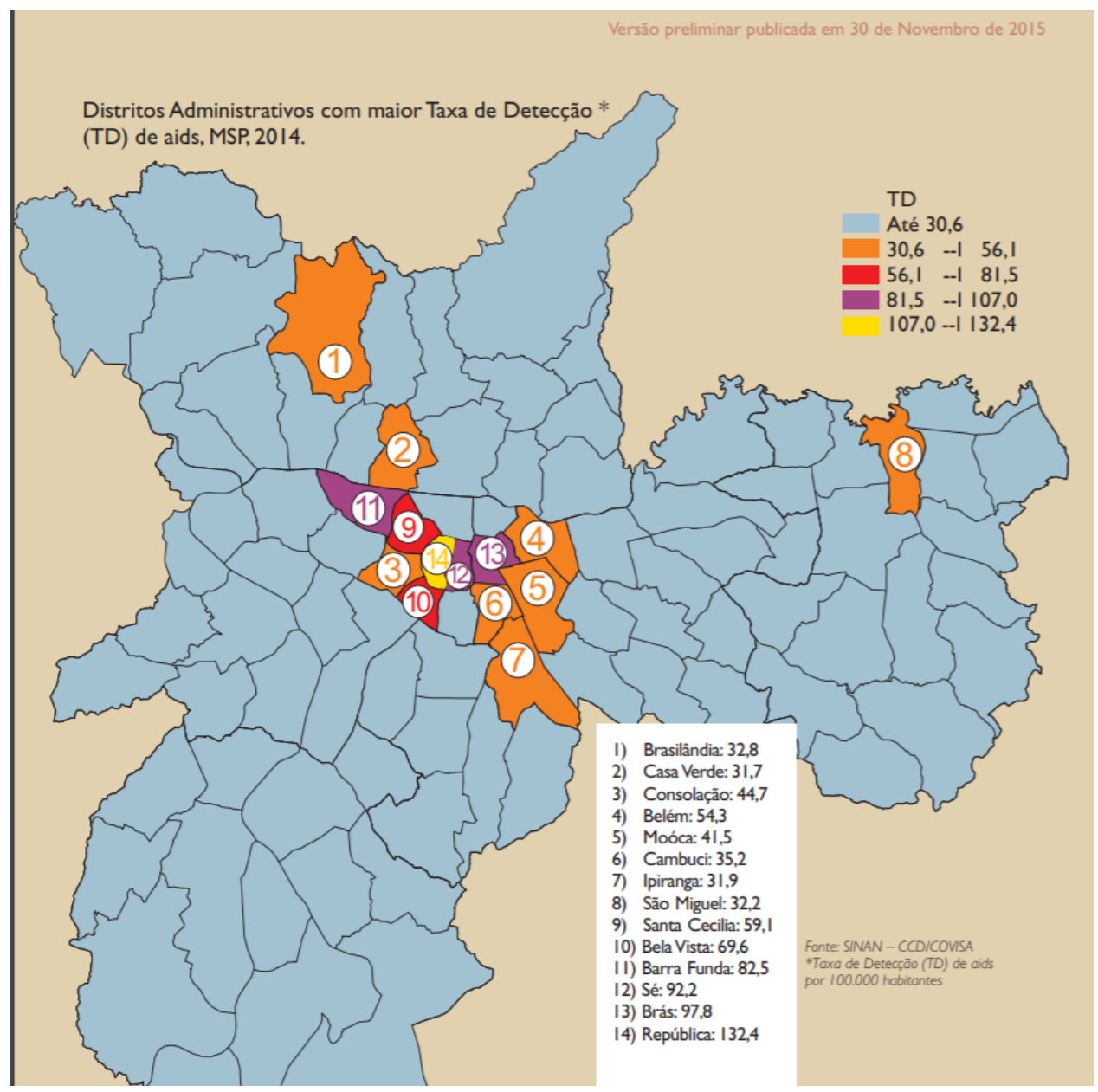

Fonte: São Paulo, 2015.

O número de novos casos é significativo nos grupos mais vulneráveis, como jovens, idosos, homossexuais e homens que fazem sexo com homens (HSH), os quais apresentam uma alta incidência de novos casos de HIV. De 2009 a 2018, é possível observar as mudanças na distribuição dos novos casos de HIV (Figura 2) no município, com maior concentração entre os homens jovens, principalmente nas faixas etárias entre 20 e 29 anos (São Paulo, 2019). 
Figura 2. Taxa de detecção, por 100 mil habitantes, de infecção pelo HIV notificada em pessoas com 15 anos de idade ou mais, de acordo com a faixa etária e o sexo - município de São Paulo - 2009 e 2018.

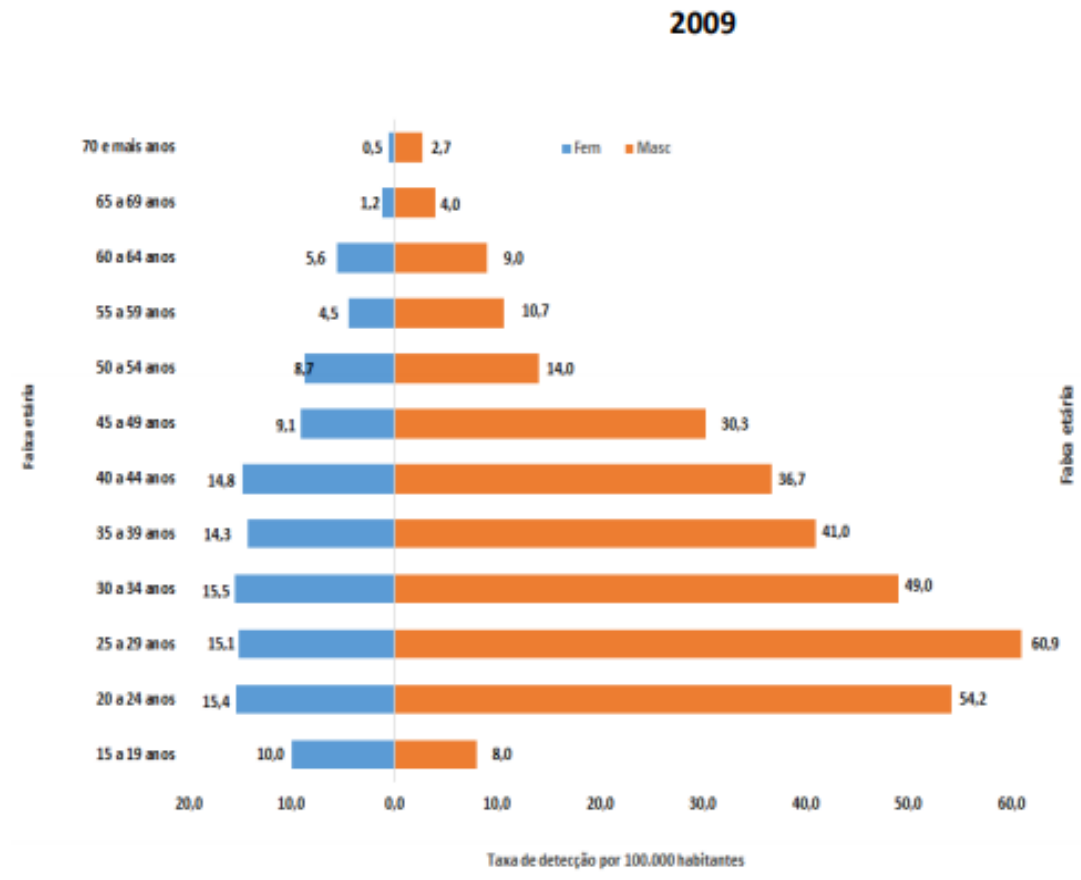

70 e mals anos
65 a 69 anos
60 a 64 anos
55 a 59 anos
50 a 54 anos
45 a 49 anos
40 a 44 anos
35 a 39 anos
30 a 34 anos
25 a 29 anos
20 a 24 anos
15 a 19 anos
70.0

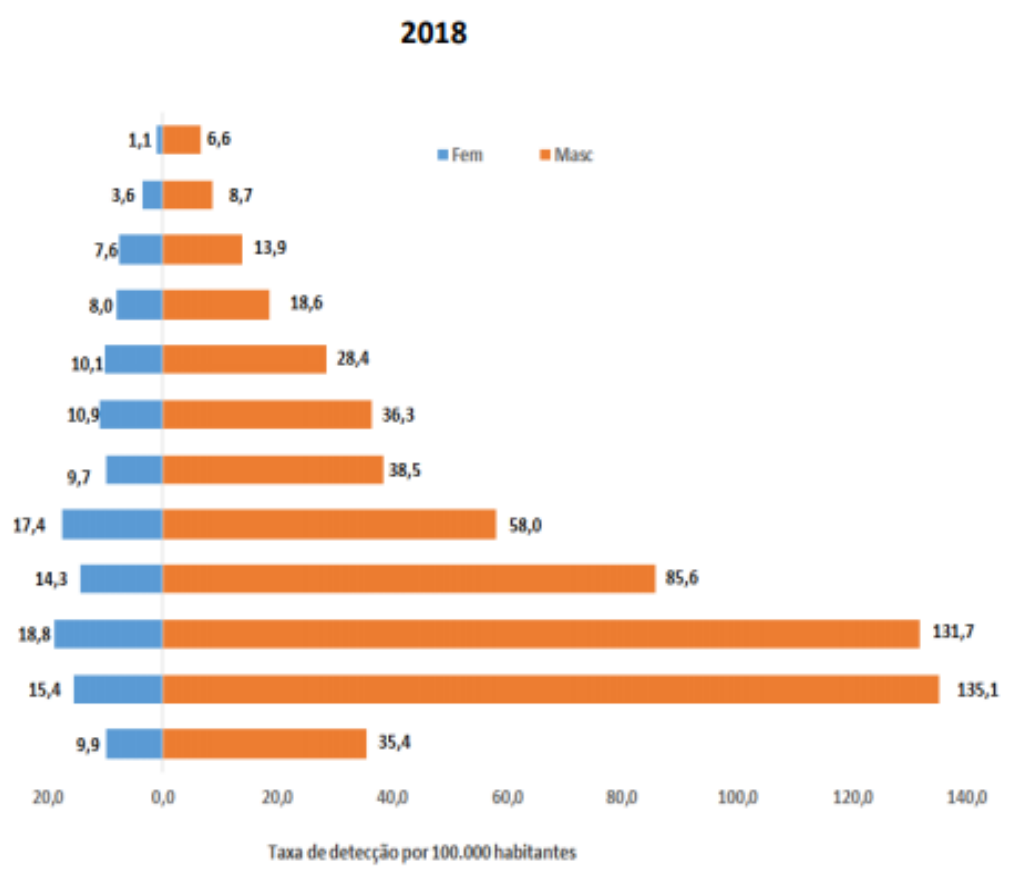

Fonte: São Paulo, 2015 


\subsection{PREVENÇÃO COMBINADA E EM DESTAQUE À PROFILAXIA PÓS- EXPOSIÇÃO DE RISCO AO HIV}

O país tem intensificado suas ações para o controle e a redução de novos casos de HIV/aids. Além da disponibilização da testagem, com o "tratamento para todos", o Governo Federal financia o tratamento integral para pessoas vivendo com HIV/aids. Desde 2013, com o início da disponibilização do tratamento, a TARV pode ser acessada nas unidades de saúde especializadas; boa parte dos usuários fazem uso do dolutegravir, considerado um dos melhores medicamentos no tratamento ao HIV, disponível gratuitamente através do Sistema Único de Saúde (SUS) (Brasil, 2018a). Além disso, há a prevenção combinada (Figura 3), que é a associação de diferentes métodos preventivos para reduzir e evitar a transmissão do HIV e de outras infecções sexualmente transmissíveis (IST) (Brasil, 2018b).

Figura 3. Mandala de prevenção combinada.

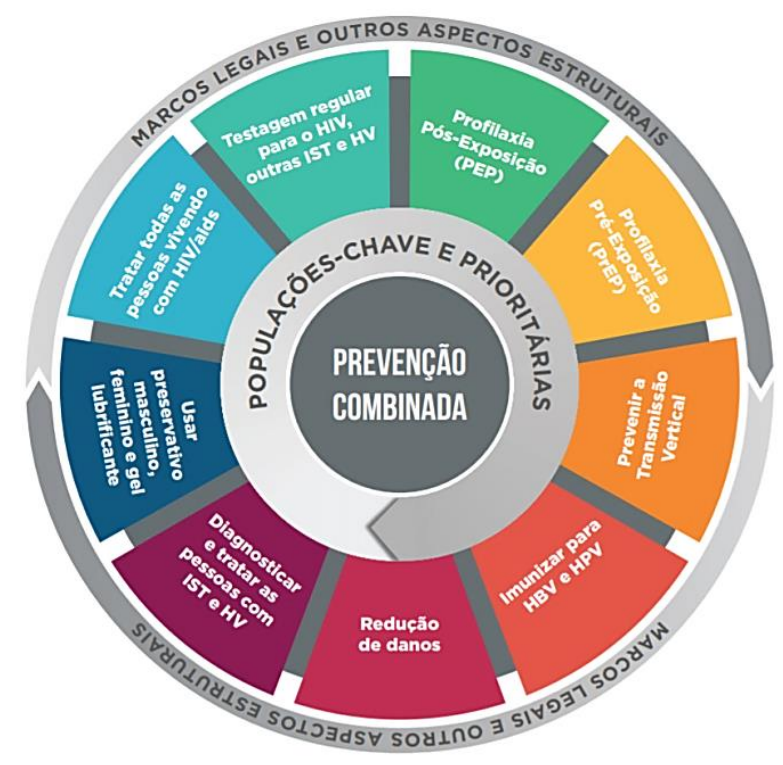

Fonte: Brasil, 2017b.

A prevenção combinada é um conjunto de diversas estratégias destinadas à prevenção do HIV, que podem ser realizadas de maneira associada a intervenções comportamentais, estruturais e biomédicas - entretanto, sem a substituição de um método por outro. Essas ações podem ser aplicadas aos usuários de acordo com suas necessidades, pois, nesse modelo de prevenção, o usuário do serviço de saúde é quem deve escolher o método que ele considera 
mais adequado, a depender de suas condições de vida, com as orientações recebidas dos profissionais de saúde (Brasil, 2017c).

As estratégias utilizadas no modelo biomédico são: o uso de preservativos penianos ou vaginais, o gel lubrificante, a profilaxia pré-exposição (PrEP) e a PEP - sendo esta última o foco do presente estudo (Brasil, 2017b).

Quanto ao modelo comportamental, as ações são voltadas para que o usuário do serviço de saúde tenha maior informação e percepção sobre o risco do HIV. Ademais, há incentivos para mudanças de comportamentos do usuário e do grupo social do qual ele participa. Na prática, essas ações envolvem o incentivo à utilização de preservativos, adesão ao serviço de saúde e redução de danos para usuários que fazem uso abusivo de álcool e outras drogas (Brasil, 2017b).

Por fim, as intervenções em níveis estruturais são ações voltadas para as condições socioculturais dos usuários do serviço de saúde. Na prática, essas ações trabalham para promover campanhas educativas, de conscientização e defesa dos direitos humanos na luta contra o racismo e o sexismo, por exemplo (Brasil, 2017b).

Apesar de todos esses avanços e do uso de diferentes estratégias, como a prevenção combinada, o número de casos de pessoas vivendo com HIV e as novas infecções pelo vírus ainda são expressivos no país, indicando que ainda há falhas na utilização de métodos preventivos, principalmente nos grupos sociais que sofrem com o estigma e o preconceito (Kerr et al., 2018). Entre os métodos preventivos pouco conhecidos no Brasil, estão a PrEP, que fornece proteção de $96 \%$ em prática anal e consiste no uso de um medicamento com combinação de dois antirretrovirais - tenofovir associado à entricitabina (TDF/FTC) - por pelo menos quatro dias da semana (Anderson, et al., 2011), e a PEP, que é indicada após suposta exposição ao vírus.

A PEP consiste no uso de antirretrovirais (ARV), com combinações de duas ou três drogas, durante um período de 28 dias. Deve ser iniciada em até 72 horas após a possível exposição ao HIV, na tentativa de evitar a transmissão do vírus (Roland et al., 2005; Schechter et al., 2004). O início tardio da profilaxia implica na redução de sua eficácia, ou seja, quanto mais tempo o paciente levar para iniciar a PEP, menor será a efetividade dos ARV (Irvine, 2015; Beymer, 2018).

No início, a PEP era usada para prevenção após contato com agulhas e com fluidos corporais em profissionais da saúde (Izulla et al., 2013). Estudos com profissionais que tiveram uma possível exposição ao vírus mostraram a eficácia e a importância da profilaxia; um estudo de caso-controle sobre uso da PEP ao HIV por exposição ocupacional identificou 
que a possibilidade de transmissão pode ser diminuída em $81 \%$ quando a profilaxia é utilizada corretamente (Cardo et al., 1997). Em outros estudos, em que a PEP foi empregada para evitar uma possível infecção de transmissão vertical, recém-nascidos fizeram uso dos ARV, e a profilaxia teve efeito protetor ao HIV, evitando que os bebês fossem infectados pelo vírus (Sperling et al., 1996; Wade et al., 1998; Tsai, 1998). Dessa forma, com base em estudos com seres humanos e animais, a PEP passou a ser recomendada pela Organização das Nações Unidas (ONU) e pelo CDC dos EUA (Ford et al., 2015; CDC, 2016).

Na atualidade, a PEP é usada como uma intervenção de prevenção mais ampla, sendo uma ação voltada às pessoas que tiveram exposição sexual desprotegida, seja por motivo de violência, sexo sem proteção, ou quando, de alguma forma, houve falha no uso do preservativo (Schechter, 2016).

A PEP deve ser iniciada em até 72 horas, após uma possível exposição ao vírus por meio de fluidos corporais que entram em contato com a mucosa, segundo o protocolo clínico e diretrizes terapêuticas (PCDT) (Brasil, 2018c). É possível acessar a PEP por meio dos Centros de Referência e Tratamento (CRT), Serviços de Atenção Especializada (SAE) e Centros de Testagem e Aconselhamento de IST/aids (CTA), pronto-socorro (PS), alguns hospitais e as Assistências Médicas Ambulatoriais (AMA) (São Paulo, 2014).

O esquema de medicamentos preferencialmente usado é tenofovir/lamivudina (TDF + 3TC) com o dolutegravir (DTG), mas podem ocorrer outras prescrições, a depender dos critérios médicos (Brasil, 2018b). Essas recomendações são administradas seguindo documentos oficiais que auxiliam no melhor cuidado à saúde e que permitem um melhor direcionamento ao tratamento, apresentando os critérios que devem ser seguidos pelo profissional de saúde ao atender o paciente. Segundo esses documentos, a recomendação da profilaxia não deve se basear no tipo de exposição, e sim no risco de exposição ao HIV; esses protocolos norteiam as ações de prevenção e tratamento ao HIV/aids no município de São Paulo (Brasil, 2018c).

O município de São Paulo conta com a disponibilidade da prevenção combinada. De acordo com o Manual de Prevenção (2017), todo município deve oferecer a PEP 24 horas por dia, por meio da rede de atendimento pelos serviços de saúde. Os hospitais e os PS fazem o atendimento aos finais de semana e/ou nos horários em que os serviços especializados estão fechados e fornecem as doses necessárias até que o usuário consiga atendimento em um desses serviços especializados (São Paulo, 2017). Porém, para que a PEP tenho o efeito desejado, a adesão aos ARV é de suma importância. 
Com essa análise, pode-se constatar que a PEP representa uma medida para tentar reduzir as taxas de infecção pelo HIV, uma vez que qualquer indivíduo, ao ter exposição ao vírus, poderá receber a profilaxia, a qual deve estar disponível 24h. Entretanto, é válido ressaltar que as populações mais vulneráveis socialmente, já citadas, têm dificuldades de acesso às medidas preventivas e de tratamento ao HIV/aids, indicando maior exposição à doença.

\subsection{ADESÃO À PROFILAXIA PÓS-EXPOSIÇÃO DE RISCO AO HIV: REVISÃO DA LITERATURA}

Para realizar a revisão da literatura sobre adesão à PEP, foram utilizadas as bases de dados: Biblioteca Virtual em Saúde (BVS), Cinahl, PubMed e Embase, somadas a artigos das referências da literatura encontrada; considerou-se que essas bases abrangem uma diversidade de tópicos relacionados à Enfermagem, dando subsídio à temática abordada neste estudo. Como pergunta norteadora, teve-se: "Como ocorre a adesão à PEP em usuários expostos ao HIV?’. Para a construção da estratégia de busca, foram usados descritores e palavras-chave indicados no quadro a seguir. O filtro de busca foi até 5/11/2019, data-limite de incorporação de artigos encontrados nas referências da literatura.

Quadro 1. Bases de dados, descritores e palavras-chave usados na estratégia de busca para revisão da literatura. São Paulo, 2020.

\begin{tabular}{|l|l|}
\hline Bases & Estratégia de busca \\
\hline BVS & $\begin{array}{l}\text { tw:((tw:(profilaxia pós-exposição)) AND (tw:(fármacos anti-hiv)) AND } \\
(\text { tw:(adesão à medicação)) })\end{array}$ \\
\hline CINAHL & $\begin{array}{l}\text { post exposure prophylaxis AND anti-hiv agents AND medication adherence } \\
\text { OR medication compliance }\end{array}$ \\
\hline PUBMED & $\begin{array}{l}\text { post exposure prophylaxis AND anti-hiv agents AND medication adherence } \\
\text { OR medication compliance }\end{array}$ \\
\hline EMBASE & $\begin{array}{l}\text { ('post exposure prophylaxis'/exp AND ('medication compliance'/exp OR } \\
\text { 'medication adherence') }\end{array}$ \\
\hline
\end{tabular}

Fonte: Elaboração própria.

Na seleção, foram incluídos artigos científicos publicados em inglês, espanhol ou português, população com 18 anos ou mais, sem restrição do ano de publicação e disponíveis 
na íntegra. Como critérios de exclusão: artigos que tratavam apenas de exposição ocupacional ao HIV, agressão sexual, transmissão vertical, resumos e pôsteres apresentados em eventos científicos, trabalhos com foco em crianças ou revisões literárias já realizadas.

Para melhor organização da busca bibliográfica, foi seguida a ordem: busca nas bases de dados através dos descritores e palavras-chave, seleção por título e resumo, eliminação dos artigos duplicados e, por fim, a leitura na íntegra dos artigos restantes.

Para mapeamento dos dados, foram extraídas as informações dos estudos em relação ao país de publicação, ao tamanho da amostra, como foi verificada a adesão e o percentual de adesão e não adesão, aos condicionantes para adesão e não adesão, aos efeitos colaterais do uso do medicamento e a se houve soroconversão. Para tabelamento dos artigos, utilizouse o programa Excel, e a organização das referências foi feita no software Mendeley para uma melhor sistematização dos estudos e para identificar duplicidades. A seguir, é mencionada a esquematização do processo (Figura 4).

Figura 4. Fluxograma de seleção dos artigos, de acordo com as bases bibliográficas utilizadas - São Paulo - 2018.

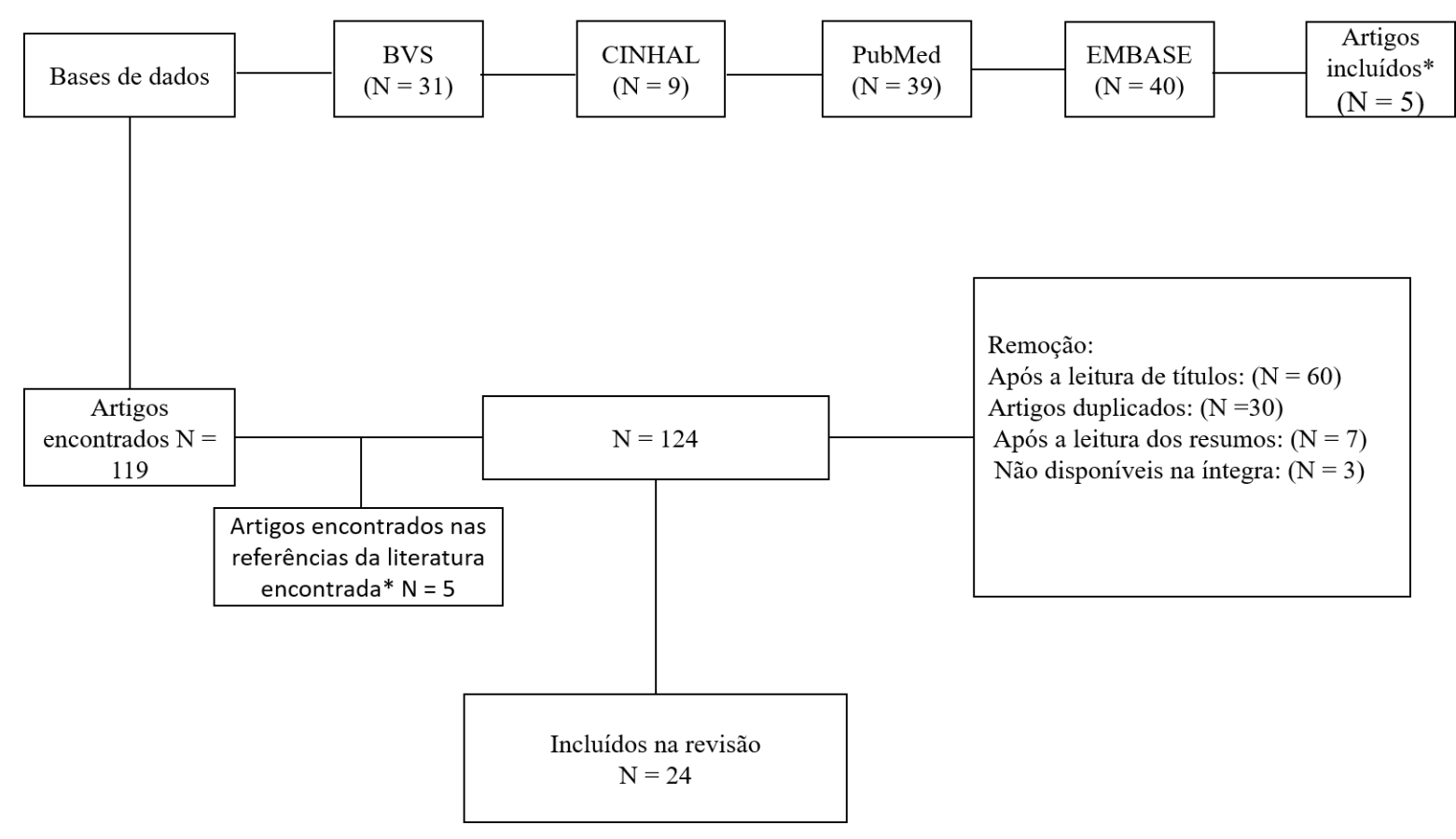

Fonte: Elaboração própria.

* artigos incorporados das referências encontradas

Dentre os 24 artigos incluídos na revisão, houve predomínio de publicações dos EUA, com nove artigos (37,5\%); seguidos por Austrália, com três (12,5\%); Canadá, Bélgica, Espanha e Brasil, com dois (8,3\%); e, por fim, França, Reino Unido, Israel e Irã, com um 
artigo (4,2\%). Nesse sentido, é notável a escassez de estudos no mundo e no Brasil em relação à adesão à PEP. Nos estudos encontrados, além da adesão aos medicamentos, outros pontos foram identificados, como presença de condicionantes que tendem a interferir na adesão e na não adesão a PEP, os efeitos colaterais referentes aos ARV e se houve ou não a soroconversão ao HIV (Quadro 2). 
Quadro 2. Distribuição dos estudos encontrados na revisão, segundo país de publicação, autor, ano, desenho do estudo, tamanho da amostra e informações sobre a adesão, seus condicionantes, presença de efeitos adversos e soroconversão. São Paulo, 2020.

\begin{tabular}{|c|c|c|c|c|c|c|}
\hline País & Autores & $\begin{array}{l}\text { Ano de } \\
\text { publicação }\end{array}$ & $\begin{array}{l}\text { Como foi verificada a adesão } \\
\text { e o percentual de adesão }\end{array}$ & $\begin{array}{l}\text { Condicionantes para adesão e } \\
\text { não adesão }\end{array}$ & $\begin{array}{l}\text { Efeitos } \\
\text { colaterais }\end{array}$ & Soroconversão \\
\hline EUA & Kahn et al. & 2001 & $\begin{array}{l}\text { Por autorrelato sobre a tomada } \\
\text { do medicamento nos quatro } \\
\text { dias anteriores a } \\
\text { acompanhamento do estudo. } \\
78 \% \text { dos usuários foram } \\
\text { aderentes. }\end{array}$ & $\begin{array}{l}\text { Adesão: a depender do regime } \\
\text { ofertado; pessoas tratadas com } \\
\text { didanosina mais estavudina foram } \\
\text { mais aderentes do que aqueles que } \\
\text { receberam zidovudina mais } \\
\text { lamivudina (94\% e } 76 \% \text {, } \\
\text { respectivamente); e } \\
\text { aconselhamento durante as visitas } \\
\text { pode ter favorecido a adesão. } \\
\text { Não adesão: toxicidades do } \\
\text { medicamento e reavaliação do } \\
\text { risco de exposição ao HIV, } \\
\text { incluindo a determinação de que a } \\
\text { fonte de exposição não estava } \\
\text { infectada pelo HIV. }\end{array}$ & $\begin{array}{l}\text { Náusea, fadiga, } \\
\text { cefaleia, } \\
\text { diarreia } \\
\text { anorexia. }\end{array}$ & $\begin{array}{l}\text { Não houve } \\
\text { soroconversão }\end{array}$ \\
\hline EUA & Landovitz et al. & 2012 & $\begin{array}{l}\text { Por autorrelato sobre da } \\
\text { tomada do medicamento pela } \\
\text { contagem de pílulas nos dias } \\
14 \text { e } 28.71,4 \% \text { dos usuários } \\
\text { terminaram a PEP. }\end{array}$ & $\begin{array}{l}\text { Adesão: a abstinência de } \\
\text { metanfetaminas durante a } \\
\text { profilaxia aumentou a adesão à } \\
\text { PEP e as chances de conclusão da } \\
\text { profilaxia. } \\
\text { Não adesão: mais anos de uso da } \\
\text { droga tendeu a diminuir a adesão. }\end{array}$ & $\begin{array}{l}\text { Dor abdominal, } \\
\text { diarreia e } \\
\text { flatulência. }\end{array}$ & $\begin{array}{l}\text { Uma } \\
\text { soroconversão } \\
\text { que relatou várias } \\
\text { exposições } \\
\text { subsequentes. }\end{array}$ \\
\hline
\end{tabular}




\begin{tabular}{|c|c|c|c|c|c|c|}
\hline País & Autores & $\begin{array}{l}\text { Ano de } \\
\text { publicação }\end{array}$ & $\begin{array}{l}\text { Como foi verificada a adesão } \\
\text { e o percentual de adesão }\end{array}$ & $\begin{array}{l}\text { Condicionantes para adesão e } \\
\text { não adesão }\end{array}$ & $\begin{array}{l}\text { Efeitos } \\
\text { colaterais }\end{array}$ & Soroconversão \\
\hline EUA & Mayer et al. & 2012 & $\begin{array}{l}\text { Por meio da contagem dos } \\
\text { comprimidos nos dias } 14 \text { e } 28 \text {, } \\
57 \% \text { foram aderentes } \\
\text { conforme a prescrição e } 27 \% \\
\text { tomavam seus remédios } \\
\text { diariamente. }\end{array}$ & $\begin{array}{l}\text { O estudo avaliou se uma } \\
\text { prescrição da PEP com três } \\
\text { medicamentos seria bem tolerada. } \\
\text { Não relatou condicionantes. }\end{array}$ & $\begin{array}{l}\text { Náusea, } \\
\text { vômito, dor de } \\
\text { cabeça, fadiga, } \\
\text { diarreia, dor } \\
\text { abdominal } \\
\text { gases } \\
\text { mialgias } \\
\text { artralgias. }\end{array}$ & $\begin{array}{l}\text { Não houve } \\
\text { soroconversões. }\end{array}$ \\
\hline EUA & Fletcher et al. & 2013 & $\begin{array}{l}\text { A aderência proporcional à } \\
\text { PEP foi definida como o } \\
\text { número de doses tomadas } \\
\text { (autorrelato) dividido pelo } \\
\text { número total de doses } \\
\text { prescritas (por exemplo, } \\
\text { X/28). Se a um participante } \\
\text { faltou mais do que } 3 \text { doses } \\
\text { consecutivas, } \\
\text { descontinuado foi } \\
\text { medicamento e considerado } \\
\text { como não tendo atingido a } \\
\text { conclusão da profilaxia; } \\
71,4 \% \text { tomaram o suficiente } \\
\text { para evitar a interrupção da } \\
\text { PEP, } 48,6 \% \text { tomaram todas as } \\
28 \text { doses do medicamento, } \\
62,9 \% \text { dos iniciadores } \\
\text { atingiram adesão } \geq 90 \% \text {. } \\
22,9 \% \text { não completaram } \\
\text { metade do regime de } \\
\text { tratamento de } 28 \text { dias. } 71,4 \%\end{array}$ & $\begin{array}{l}\text { Não adesão: o número de IST ao } \\
\text { longo da vida dos participantes e } \\
\text { outras exposições anais sem } \\
\text { preservativo. Para cada IST } \\
\text { adicional relatada, a adesão } \\
\text { proporcional ao medicamento dos } \\
\text { participantes diminuiu em } 7 \% \text {, e } \\
\text { suas chances de conclusão do } \\
\text { curso reduziram em cerca de } 31 \% \text {. } \\
\text { Para cada episódio adicional de } \\
\text { exposição anal desprotegida nos } \\
\text { últimos seis meses, a adesão } \\
\text { proporcional aos medicamentos } \\
\text { pelos participantes diminuiu em } \\
1 \% \text { e suas chances de completar o } \\
\text { curso de PEP reduziram em cerca } \\
\text { de } 6 \% \text {. }\end{array}$ & $\begin{array}{l}\text { O estudo não } \\
\text { relata efeito } \\
\text { colateral. }\end{array}$ & $\begin{array}{l}\text { Uma } \\
\text { soroconversão } \\
\text { em um usuário } \\
\text { que não aderiu ao } \\
\text { medicamento e } \\
\text { teve exposições } \\
\text { subsequentes. }\end{array}$ \\
\hline
\end{tabular}




\begin{tabular}{|c|c|c|c|c|c|c|}
\hline País & Autores & $\begin{array}{l}\text { Ano de } \\
\text { publicação }\end{array}$ & $\begin{array}{l}\text { Como foi verificada a adesão } \\
\text { e o percentual de adesão }\end{array}$ & $\begin{array}{l}\text { Condicionantes para adesão e } \\
\text { não adesão }\end{array}$ & $\begin{array}{l}\text { Efeitos } \\
\text { colaterais }\end{array}$ & Soroconversão \\
\hline & & & $\begin{array}{lrr}\text { continuaram tomando } & \text { o } \\
\text { medicamento com frequência } \\
\text { suficiente para evitar } & \text { a } \\
\text { descontinuação } & & \text { e } \\
\text { completaram } & \text { o } & \text { curso } \\
\text { prescrito. } & & \end{array}$ & & & \\
\hline Austrália & McAllister et al. & 2014 & $\begin{array}{l}\text { Por meio da contagem de } \\
\text { comprimidos nas semanas } 2,4 \\
\text { e } 5 \text { e calculada dividindo-se o } \\
\text { número de doses retornadas } \\
\text { pelo número de doses } \\
\text { dispensadas. } \\
\text { Taxa de adesão ao } \\
\text { medicamento: } 89 \% \text { para } 3 \\
\text { fármacos e } 90 \% \text { para } 2 \\
\text { fármacos. Taxa de conclusão } \\
\text { da PEP, medicamento e } \\
\text { retorno: } 92 \% \text { que terminaram }\end{array}$ & $\begin{array}{l}\text { Não houve diferença para adesão } \\
\text { entre os diferentes regimes } \\
\text { oferecidos. }\end{array}$ & $\begin{array}{l}\text { Fadiga, } \\
\text { sonolência, } \\
\text { suor, sede, } \\
\text { diminuição da } \\
\text { libido, náuseas, } \\
\text { inchaço, } \\
\text { cólicas } \\
\text { abdominais, } \\
\text { diminuição do } \\
\text { apetite, } \\
\text { flatulência, } \\
\text { diarreia, }\end{array}$ & $\begin{array}{l}\text { Não } \quad \text { houve } \\
\text { soroconversão. }\end{array}$ \\
\hline
\end{tabular}




\begin{tabular}{|c|c|c|c|c|c|c|}
\hline País & Autores & $\begin{array}{l}\text { Ano de } \\
\text { publicação }\end{array}$ & $\begin{array}{l}\text { Como foi verificada a adesão } \\
\text { e o percentual de adesão }\end{array}$ & $\begin{array}{l}\text { Condicionantes para adesão e } \\
\text { não adesão }\end{array}$ & $\begin{array}{l}\text { Efeitos } \\
\text { colaterais }\end{array}$ & Soroconversão \\
\hline & & & $\begin{array}{l}\text { a PEP tomaram } 3 \text { fármacos e } \\
91 \% \text { que terminaram usaram } 2 \\
\text { fármacos. }\end{array}$ & & $\begin{array}{l}\text { insônia, } \\
\text { depressão, } \\
\text { tontura. }\end{array}$ & \\
\hline Canadá & Bogoch et al. & 2014 & $\begin{array}{l}\text { Por autorrelato sobre a tomada } \\
\text { dos medicamentos durante as } \\
\text { consultas de acompanhamento } \\
\text { ou por telefonemas e revisão } \\
\text { de prontuários. } \\
\text { Critérios de adesão: se } \\
\text { tomaram mais de } 95 \% \text { das } \\
\text { pílulas prescritas ao longo de } \\
28 \text { dias. } \\
\text { Critérios para não adesão: } \\
\text { menos de 95\% das pílulas } \\
\text { prescritas ou tinham adesão } \\
\text { desconhecida devido à falta de } \\
\text { acompanhamento } \\
\text { consultas e à incapacidade de } \\
\text { contatá-los por telefone ou e- } \\
\text { mail. } \\
\text { Percentual: } 54,4 \% \text { não } \\
\text { retornaram após a primeira } \\
\text { consulta, 45,6\% não }\end{array}$ & $\begin{array}{l}\text { Adesão: usuários que conheciam } \\
\text { um indivíduo soropositivo. } \\
\text { Não adesão: usuários que eram do } \\
\text { sexo feminino e com idade } \\
\text { avançada. }\end{array}$ & $\begin{array}{l}\text { O estudo não } \\
\text { mencionou } \\
\text { efeitos } \\
\text { colaterais. }\end{array}$ & $\begin{array}{l}\text { O estudo não } \\
\text { mencionou } \\
\text { soroconversão. }\end{array}$ \\
\hline
\end{tabular}




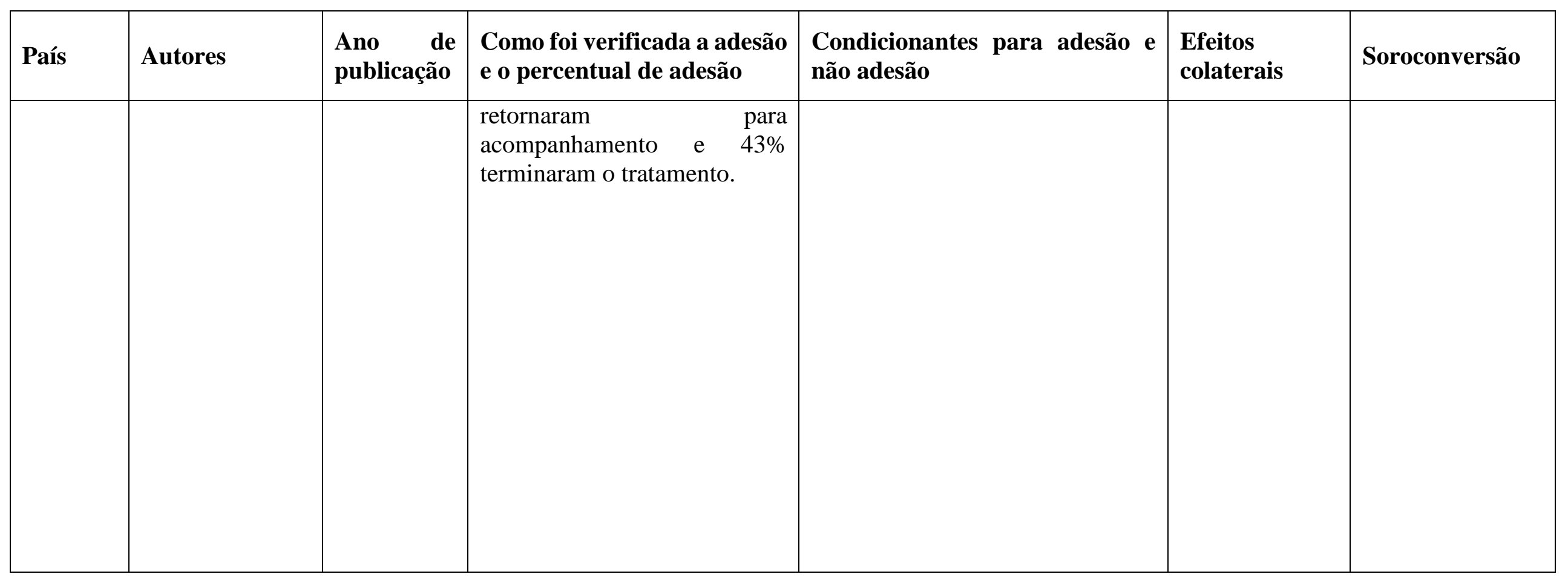




\begin{tabular}{|c|c|c|c|c|c|c|}
\hline País & Autores & $\begin{array}{l}\text { Ano de } \\
\text { publicação }\end{array}$ & $\begin{array}{l}\text { Como foi verificada a adesão } \\
\text { e o percentual de adesão }\end{array}$ & $\begin{array}{l}\text { Condicionantes para adesão e } \\
\text { não adesão }\end{array}$ & $\begin{array}{l}\text { Efeitos } \\
\text { colaterais }\end{array}$ & Soroconversão \\
\hline EUA & Landovitz et al. & 2014 & $\begin{array}{l}\text { A partir de registros nas } \\
\text { farmácias, contagem de } \\
\text { comprimidos e autorrelato. }\end{array}$ & $\begin{array}{l}\text { O estudo trabalhou com grupo de } \\
\text { HSH que fazia o uso de } \\
\text { estimulantes. O grupo-controle, } \\
\text { que recebeu gestão de } \\
\text { contingência, tendeu a uma maior } \\
\text { adesão à PEP. }\end{array}$ & $\begin{array}{l}\text { O estudo não } \\
\text { menciona } \\
\text { efeitos } \\
\text { colaterais. }\end{array}$ & $\begin{array}{l}\text { O estudo não } \\
\text { menciona } \\
\text { soroconversão. }\end{array}$ \\
\hline Canadá & Thomas et al. & 2015 & $\begin{array}{l}\text { Critério de adesão: foram } \\
\text { considerados os usuários que } \\
\text { não perderam mais de } 5 \text { doses } \\
\text { durante a profilaxia } \\
\text { (autorrelato). } \\
\text { Percentual de adesão: } 69 \% \text { dos } \\
\text { usuários relataram tomar os } \\
\text { medicamentos todos os dias. }\end{array}$ & $\begin{array}{l}\text { Adesão: usuários que estavam } \\
\text { fazendo a PEP pela primeira vez, } \\
\text { pacientes mais velhos e do sexo } \\
\text { masculino e que tomaram } \\
\text { esquemas baseados em } \\
\text { tenofovir/entricitabina. } \\
\text { Não adesão: usuários que tiveram } \\
\text { algum efeito adverso e que } \\
\text { tomaram esquemas baseados em } \\
\text { zidovudina/lamivudina. }\end{array}$ & $\begin{array}{l}\text { O estudo não } \\
\text { menciona } \\
\text { efeitos } \\
\text { colaterais. }\end{array}$ & $\begin{array}{l}\text { Houve } 10 \text { casos } \\
\text { de } \\
\text { soroconversão; } 9 \\
\text { usuários tiveram } \\
\text { outras exposições } \\
\text { de risco durante a } \\
\text { tomada do } \\
\text { medicamento e } \\
\text { um foi } \\
\text { considerado uma } \\
\text { possível falha da } \\
\text { PEP. }\end{array}$ \\
\hline
\end{tabular}




\begin{tabular}{|c|c|c|c|c|c|c|}
\hline País & Autores & $\begin{array}{l}\text { Ano de } \\
\text { publicação }\end{array}$ & $\begin{array}{l}\text { Como foi verificada a adesão } \\
\text { e o percentual de adesão }\end{array}$ & $\begin{array}{l}\text { Condicionantes para adesão e } \\
\text { não adesão }\end{array}$ & $\begin{array}{l}\text { Efeitos } \\
\text { colaterais }\end{array}$ & Soroconversão \\
\hline Austrália & Foster et al. & 2015 & $\begin{array}{l}\text { Por meio do retorno ao serviço } \\
\text { de saúde, autorrelato sobre a } \\
\text { tomada do medicamento e por } \\
\text { concentrações plasmáticas dos } \\
\text { medicamentos. } \\
\text { A conclusão da PEP foi de } \\
92 \% ; 6 \% \text { pararam de tomar o } \\
\text { medicamento, } 73 \% \text { deixaram } \\
\text { de tomar alguma dose e, dos } \\
\text { que terminaram a PEP, } \\
\text { nenhum informou ter faltado } \\
\text { com mais de } 3 \text { doses. }\end{array}$ & $\begin{array}{l}\text { O uso anterior da PEP não foi } \\
\text { associado com a adesão. }\end{array}$ & $\begin{array}{l}\text { Depressão } \\
\text { clínica, } \\
\text { dificuldade de } \\
\text { concentração, } \\
\text { fadiga, diarreia } \\
\text { e acne. }\end{array}$ & $\begin{array}{l}\text { Não houve } \\
\text { soroconversão. }\end{array}$ \\
\hline EUA & Hugo et al. & 2016 & $\begin{array}{l}\text { Por autorrelato, } 58,5 \% \\
\text { completaram a PEP, } 31,7 \% \\
\text { relataram que faltou uma dose } \\
\text { de PEP e 9,8\% relataram que } \\
\text { faltou mais de uma dose. }\end{array}$ & $\begin{array}{l}\text { Adesão: usuários que tomaram } \\
\text { medicamentos uma vez por dia. } \\
\text { Não adesão: usuários que } \\
\text { tomaram medicamentos duas } \\
\text { vezes ao dia. }\end{array}$ & $\begin{array}{l}\text { Náuseas, } \\
\text { vômitos } \\
\text { diarreia, dores } \\
\text { de cabeça, } \\
\text { erupção } \\
\text { cutânea, } \\
\text { cansaço, falta } \\
\text { de energia e } \\
\text { sentir-se } \\
\text { deprimido. }\end{array}$ & $\begin{array}{l}\text { O estudo não } \\
\text { mencionou } \\
\text { soroconversão. }\end{array}$ \\
\hline
\end{tabular}




\begin{tabular}{|c|c|c|c|c|c|c|}
\hline País & Autores & $\begin{array}{l}\text { Ano de } \\
\text { publicação }\end{array}$ & $\begin{array}{l}\text { Como foi verificada a adesão } \\
\text { e o percentual de adesão }\end{array}$ & $\begin{array}{l}\text { Condicionantes para adesão e } \\
\text { não adesão }\end{array}$ & $\begin{array}{l}\text { Efeitos } \\
\text { colaterais }\end{array}$ & Soroconversão \\
\hline Bélgica & Malinverni et al. & 2016 & $\begin{array}{l}\text { Por meio de registros médicos } \\
\text { ou da farmácia em relação à } \\
\text { retirada de medicamentos. } \\
\text { Não adesão: como os } \\
\text { medicamentos eram } \\
\text { distribuídos conforme os } \\
\text { retornos, foram considerados } \\
\text { não aderentes os usuários que } \\
\text { receberam o medicamento } \\
\text { para mais que um dia e menos } \\
\text { que } 28 \text {. }\end{array}$ & $\begin{array}{l}\text { A adesão das vítimas de agressão } \\
\text { sexual foi menor do que com } \\
\text { outras exposições, com apenas } \\
40 \% \text { completando o regime de } 28 \\
\text { dias. Três pacientes } \\
\text { interromperam o tratamento por } \\
\text { causa dos efeitos colaterais. }\end{array}$ & $\begin{array}{l}20 \% \text { dos } \\
\text { entrevistados } \\
\text { sofreram algum } \\
\text { efeito colateral. }\end{array}$ & $\begin{array}{l}\text { Uma } \\
\text { soroconversão } 4 \\
\text { meses depois da } \\
\text { exposição em um } \\
\text { paciente HSH, } \\
\text { que não relatou } \\
\text { comportamentos } \\
\text { de risco, o que } \\
\text { representa uma } \\
\text { provável falha da } \\
\text { PEP. }\end{array}$ \\
\hline Espanha & Leal et al. & 2016 & $\begin{array}{l}\text { Por meio de um questionário } \\
\text { de adesão a medicamentos, no } \\
\text { qual o grau de adesão foi } \\
\text { calculado com base nas } \\
\text { respostas, e foi considerado } \\
\text { não adesão questionários com } \\
\text { percentil } \leq 94 \% \text {. Ademais, o } \\
\text { mesmo estudo considerou o } \\
\text { não cumprimento quando o } \\
\text { usuário perdeu o o } \\
\text { acompanhamento antes do } 28^{\circ} \\
\text { dia, quando parou ou trocou o } \\
\text { tratamento por qualquer } \\
\text { motivo ou se ele faleceu. Do } \\
\text { total (237), } 79 \% \\
\text { compareceram à primeira } \\
\text { consulta agendada e } 38 \% \text { não } \\
\text { cumpriram a PEP até o } 28^{\circ} \text { dia. }\end{array}$ & $\begin{array}{l}\text { Adesão: a depender do } \\
\text { medicamento prescrito: lopinavir } \\
\text { potenciado com ritonavir, com } \\
44 \% \text { de adesão, contra maraviroc, } \\
\text { com } 32 \% \text {. } \\
\text { Não adesão: etnia não caucasiana, } \\
\text { baixo risco de exposição e ter feito } \\
\text { uso anterior da PEP. }\end{array}$ & $\begin{array}{l}\text { Os eventos } \\
\text { adversos foram } \\
\text { relatados por } \\
111 \text { pacientes. } \\
\text { O estudo não } \\
\text { relata quais } \\
\text { foram } r \\
\text { efeitos. }\end{array}$ & $\begin{array}{l}\text { Não } \quad \text { houve } \\
\text { soroconversão. }\end{array}$ \\
\hline
\end{tabular}




\begin{tabular}{|c|c|c|c|c|c|c|}
\hline País & Autores & $\begin{array}{l}\text { Ano de } \\
\text { publicação }\end{array}$ & $\begin{array}{l}\text { Como foi verificada a adesão } \\
\text { e o percentual de adesão }\end{array}$ & $\begin{array}{l}\text { Condicionantes para adesão e } \\
\text { não adesão }\end{array}$ & $\begin{array}{l}\text { Efeitos } \\
\text { colaterais }\end{array}$ & Soroconversão \\
\hline França & Valin et al. & 2016 & $\begin{array}{l}\text { Por autorrelato sobre a tomada } \\
\text { do medicamento e } 92 \% \\
\text { completaram os } 28 \text { dias de } \\
\text { PEP. }\end{array}$ & $\begin{array}{l}\text { A idade não influenciou na } \\
\text { adesão. }\end{array}$ & $\begin{array}{l}\text { Mais de } 60 \% \\
\text { dos } \\
\text { participantes } \\
\text { relataram pelo } \\
\text { menos um } \\
\text { efeito adverso, } \\
\text { entre leves e } \\
\text { moderados: } \\
\text { fadiga, náusea } \\
\text { e vômito. }\end{array}$ & $\begin{array}{l}\text { Não houve } \\
\text { soroconversão. }\end{array}$ \\
\hline EUA & Mayer et al. & 2017 & $\begin{array}{l}\text { Por auto relato. Não houve um } \\
\text { critério pré-determinado para } \\
\text { estabelecer a adesão, } 71 \% \text { dos } \\
\text { usuários relataram ter } \\
\text { completado a profilaxia por } 28 \\
\text { dias. Apenas } 29 \% \text { não perdeu } \\
\text { nenhuma dose. }\end{array}$ & $\begin{array}{l}\text { Adesão: um único regime com } \\
\text { combinação de dose fixa de } \\
\text { elvitegravir/cobicistate/tenofovir/ } \\
\text { entricitabina, foi bem tolerado, } \\
\text { com taxas de conclusão elevadas. } \\
\text { Não adesão: esquecimento, } \\
\text { dificuldade de engolir, resfriado e } \\
\text { anorexia. }\end{array}$ & $\begin{array}{l}\text { Desconforto } \\
\text { abdominal, } \\
\text { gases, diarreia, } \\
\text { fadiga, náusea } \\
\text { ou vômito, dor } \\
\text { de cabeça ou } \\
\text { tontura. }\end{array}$ & $\begin{array}{l}\text { Não } \quad \text { houve } \\
\text { soroconversão. }\end{array}$ \\
\hline $\begin{array}{l}\text { Reino } \\
\text { Unido }\end{array}$ & Milinkovic et al. & 2017 & $\begin{array}{l}\text { Por meio da contagem de } \\
\text { comprimidos nos dias } 14 \text { e } 28 \text {. } \\
\text { A taxa de conclusão da PEP } \\
\text { foi de } 82 \% \text { para os que } \\
\text { tomaram maraviroc, contra } \\
77 \% \text { que tomaram kaletra. }\end{array}$ & $\begin{array}{l}\text { Adesão: a depender do regime } \\
\text { ofertado, } 82 \% \text { de adesão para os } \\
\text { que tomaram maraviroc, contra } \\
77 \% \text { que tomaram kaletra. }\end{array}$ & $\begin{array}{l}\text { Não menciona } \\
\text { quais foram os } \\
\text { efeitos } \\
\text { adversos. }\end{array}$ & $\begin{array}{l}\text { Não houve } \\
\text { soroconversão. }\end{array}$ \\
\hline
\end{tabular}




\begin{tabular}{|c|c|c|c|c|c|c|}
\hline País & Autores & $\begin{array}{l}\text { Ano de } \\
\text { publicação }\end{array}$ & $\begin{array}{l}\text { Como foi verificada a adesão } \\
\text { e o percentual de adesão }\end{array}$ & $\begin{array}{l}\text { Condicionantes para adesão e } \\
\text { não adesão }\end{array}$ & $\begin{array}{l}\text { Efeitos } \\
\text { colaterais }\end{array}$ & Soroconversão \\
\hline Espanha & Inciarte et al. & 2017 & $\begin{array}{l}\text { Houve critério definido para } \\
\text { adesão: foi aplicado um } \\
\text { questionário de adesão ao } \\
\text { medicamento, o mesmo usado } \\
\text { em pessoas vivendo com HIV. } \\
\text { O grau de adesão foi calculado } \\
\text { com base nas respostas de } \\
\text { cada paciente, e abaixo de } \\
94 \% \text { foi classificado como } \\
\text { baixa adesão. } \\
\text { Taxa de conclusão da PEP: } \\
36 \% \text { não retornou aos } \\
\text { acompanhamentos antes do } \\
\text { dia } 28 \text {, ou teve o tratamento } \\
\text { interrompido e/ou substituído } \\
\text { por qualquer motivo, } \\
\text { incluindo a morte. }\end{array}$ & $\begin{array}{l}\text { Adesão: a depender do regime } \\
\text { ofertado. Entre os usuários que } \\
\text { tomaram lopinavir/ritonavir, } 47 \% \\
\text { não concluíram a PEP, e, entre os } \\
\text { usuários que tomaram } \\
\text { elvitegravir/cobicistate, } 33 \% \text { não } \\
\text { concluíram a PEP. } \\
\text { Não adesão: idade abaixo da } \\
\text { mediana, efeitos adversos e o uso } \\
\text { anterior da PEP. }\end{array}$ & $\begin{array}{l}\text { Houve efeitos } \\
\text { adversos em } \\
59 \% \text { dos } \\
\text { usuários, mas } \\
\text { não foram } \\
\text { mencionados } \\
\text { quais foram. }\end{array}$ & $\begin{array}{l}\text { Uma } \\
\text { soroconversão no } \\
\text { braço } \\
\text { Elvitegravir/ } \\
\text { cobicistate. } \\
\text { Entretanto, o } \\
\text { paciente relatou } \\
\text { múltiplas } \\
\text { exposições antes } \\
\text { e após a PEP. }\end{array}$ \\
\hline Austrália & McAllister et al. & 2017 & $\begin{array}{l}\text { Por autorrelato e contagem de } \\
\text { comprimidos nas semanas } 2,4 \\
\text { e } 5 \text { (calculada dividindo-se o } \\
\text { número de doses retornadas } \\
\text { pelo número de doses } \\
\text { dispensadas), com adesão de } \\
98 \% \text {. Ademais, observou-se os } \\
\text { níveis de droga no plasma. A } \\
\text { conclusão da PEP foi de } 90 \% \\
\text { para o regime dolutegravir } \\
\text { com tenofovir disoproxil } \\
\text { fumarate-emtricitabine. }\end{array}$ & $\begin{array}{l}\text { Não adesão: os usuários que } \\
\text { tiveram efeitos adversos. }\end{array}$ & $\begin{array}{l}\text { Fadiga, náusea, } \\
\text { diarreia e dor } \\
\text { de cabeça. }\end{array}$ & $\begin{array}{l}\text { O estudo não } \\
\text { mencionou } \\
\text { soroconversão. }\end{array}$ \\
\hline
\end{tabular}




\begin{tabular}{|c|c|c|c|c|c|c|}
\hline País & Autores & $\begin{array}{l}\text { Ano de } \\
\text { publicação }\end{array}$ & $\begin{array}{l}\text { Como foi verificada a adesão } \\
\text { e o percentual de adesão }\end{array}$ & $\begin{array}{l}\text { Condicionantes para adesão e } \\
\text { não adesão }\end{array}$ & $\begin{array}{l}\text { Efeitos } \\
\text { colaterais }\end{array}$ & Soroconversão \\
\hline EUA & Beymer et al. & 2017 & $\begin{array}{l}\text { Por autorrelato sobre a tomada } \\
\text { do medicamento durante o } \\
\text { retorno ou por ligação } \\
\text { telefônica; } 87 \% \text { retornaram } \\
\text { para pelo menos } 1 \text { visita de } \\
\text { acompanhamento dentro do } \\
\text { período de acompanhamento } \\
\text { de } 6 \text { meses. }\end{array}$ & $\begin{array}{l}\text { Adesão: usuários que se } \\
\text { identificaram como do sexo } \\
\text { masculino, eram mais velhos no } \\
\text { início da PEP, tinham nível } \\
\text { superior e relataram não usar } \\
\text { metanfetamina foram mais } \\
\text { propensos a retornar para o teste } \\
\text { de HIV (seguimento). } \\
\text { Não adesão: a presença de } \\
\text { qualquer evento adverso. }\end{array}$ & $\begin{array}{l}\text { Fadiga, } \\
\text { diarreia, náusea } \\
\text { e desconforto } \\
\text { abdominal. }\end{array}$ & $\begin{array}{l}17 \text { indivíduos } \\
\text { soroconverteram, } \\
7 \text { relataram } \\
\text { exposição } \\
\text { subsequente, } 8 \\
\text { relataram uso de } \\
\text { preservativo após } \\
\text { a exposição } \\
\text { inicial e } 2 \\
\text { relataram } \\
\text { abstinência desde } \\
\text { a exposição. } \\
\text { Indivíduos que } \\
\text { relataram adesão } \\
\text { completa } \\
\text { medicamento de } \\
\text { PEP tiveram } \\
\text { menor } \\
\text { probabilidade de } \\
\text { soroconversão do } \\
\text { que aqueles que } \\
\text { relataram adesão } \\
\text { incompleta. }\end{array}$ \\
\hline Israel & $\begin{array}{l}\text { Oz Noam; } \\
\text { Danny Alon }\end{array}$ & 2017 & $\begin{array}{l}\text { Por meio de autorrelato sobre } \\
\text { a tomada do medicamento, } \\
91 \% \text { tomaram os } \\
\text { medicamentos por } 28 \text { dias. }\end{array}$ & $\begin{array}{l}\text { Adesão: melhores orientações } \\
\text { médicas em um ambiente mais } \\
\text { discreto para realizar o } \\
\text { atendimento podem melhorar a } \\
\text { adesão. }\end{array}$ & $\begin{array}{lr}84 \% & \text { dos } \\
\text { indivíduos } & \text { da } \\
\text { pesquisa } & \\
\text { relataram } & \\
\text { efeitos } & \\
\text { colaterais. } & \text { A } \\
\text { maioria } & \text { teve }\end{array}$ & $\begin{array}{l}\text { O estudo não } \\
\text { mencionou } \\
\text { soroconversão. }\end{array}$ \\
\hline
\end{tabular}




\begin{tabular}{|c|c|c|c|c|c|c|}
\hline País & Autores & $\begin{array}{l}\text { Ano de } \\
\text { publicação }\end{array}$ & $\begin{array}{l}\text { Como foi verificada a adesão } \\
\text { e o percentual de adesão }\end{array}$ & $\begin{array}{l}\text { Condicionantes para adesão e } \\
\text { não adesão }\end{array}$ & $\begin{array}{l}\text { Efeitos } \\
\text { colaterais }\end{array}$ & Soroconversão \\
\hline & & & & & $\begin{array}{l}\text { efeito } \\
\text { moderado. }\end{array}$ & \\
\hline Bélgica & Malinverni et al. & 2018 & $\begin{array}{l}\text { Por autorrelato sobre a tomada } \\
\text { do medicamento e registro do } \\
\text { retorno ao serviço de saúde, } \\
87,3 \% \text { dos usuários } \\
\text { compareceram à sua primeira } \\
\text { consulta clínica e } 66,4 \% \\
\text { tomaram os medicamentos } \\
\text { pelos } 28 \text { dias. }\end{array}$ & $\begin{array}{l}\text { Adesão: usuários do sexo } \\
\text { masculino e com seguro-saúde, e } \\
\text { os HSH. } \\
\text { Não adesão: usuários que eram } \\
\text { imigrantes e sem seguro-saúde. }\end{array}$ & $\begin{array}{l}\text { O estudo não } \\
\text { menciona } \\
\text { efeitos } \\
\text { colaterais. }\end{array}$ & $\begin{array}{l}\text { Uma } \\
\text { soroconversão } \\
\text { com provável } \\
\text { falha da PEP. }\end{array}$ \\
\hline Brasil & $\begin{array}{l}\text { M. Carneiro; D. } \\
\text { Elias }\end{array}$ & 2018 & $\begin{array}{l}\text { Por meio das análises das } \\
\text { fichas dos usuários, e } 25,7 \% \\
\text { tomaram os medicamentos por } \\
28 \text { dias. Ademais, houve relato } \\
\text { da adesão aos retornos de } \\
\text { acompanhamento. Foram } \\
\text { realizados } 3 \text { retornos. } 30,8 \% \\
\text { compareceram ao retorno } 1 \text { ( } 6 \\
\text { semanas após exposição), } \\
16,7 \% \text { ao retorno } 2 \text { ( } 3 \text { meses } \\
\text { após exposição) e apenas } 9,8 \% \\
\text { estiveram no retorno } 3 \text { ( } 6 \\
\text { meses após o acidente). }\end{array}$ & $\begin{array}{l}\text { O estudo não relata a interferência } \\
\text { dos condicionantes sobre a adesão } \\
\text { de acompanhamento em relação à } \\
\text { exposição sexual. }\end{array}$ & $\begin{array}{l}\text { Náusea, vômito } \\
\text { e mal-estar. }\end{array}$ & $\begin{array}{l}\text { Não } \quad \text { houve } \\
\text { soroconversão. }\end{array}$ \\
\hline
\end{tabular}




\begin{tabular}{|c|c|c|c|c|c|c|}
\hline País & Autores & $\begin{array}{l}\text { Ano de } \\
\text { publicação }\end{array}$ & $\begin{array}{l}\text { Como foi verificada a adesão } \\
\text { e o percentual de adesão }\end{array}$ & $\begin{array}{l}\text { Condicionantes para adesão e } \\
\text { não adesão }\end{array}$ & $\begin{array}{l}\text { Efeitos } \\
\text { colaterais }\end{array}$ & Soroconversão \\
\hline EUA & Beymer et al. & 2018 & $\begin{array}{l}\text { Por contagem de comprimidos } \\
\text { e autorrelato, } 53 \% \text { relataram } \\
\text { adesão completa ao } \\
\text { medicamento, enquanto } 26 \% \\
\text { referiram adesão incompleta } \\
\text { ao medicamento e } 21 \% \text { tinham } \\
\text { adesão ao medicamento } \\
\text { desconhecida devido à falta } \\
\text { em retorno. }\end{array}$ & 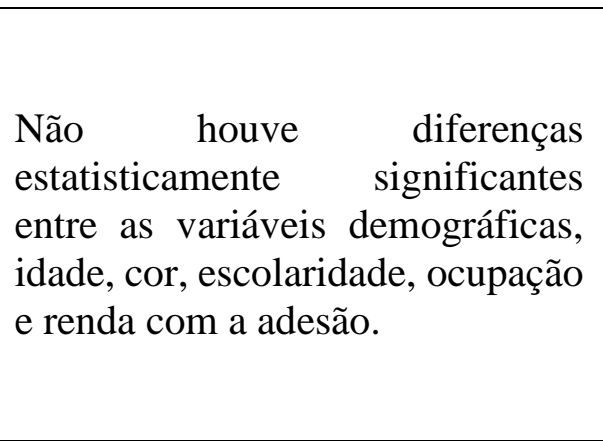 & $\begin{array}{l}\text { Desconforto } \\
\text { abdominal leve } \\
\text { a moderado, } \\
\text { seguido de } \\
\text { náusea } \quad \text { e } \\
\text { fadiga. }\end{array}$ & $\begin{array}{l}7 \\
\text { soroconverteram } \\
\text { e } 6 \text { seis tiveram } \\
\text { reexposição } \\
\text { posterior. }\end{array}$ \\
\hline Irã & $\begin{array}{l}\text { Rasoolinejad et } \\
\text { al }\end{array}$ & 2018 & $\begin{array}{l}\text { Por meio de registros de } \\
\text { prontuários. A adesão foi de } \\
60,5 \%\end{array}$ & $\begin{array}{l}\text { Não adesão: quando o usuário } \\
\text { sabia que a pessoa com quem ele } \\
\text { se relacionou não tinha HIV, } \\
\text { quando o usuário não tinha } \\
\text { dinheiro para pagar os } \\
\text { medicamentos, efeitos adversos. }\end{array}$ & $\begin{array}{l}\text { Náusea, vômito } \\
\text { e erupção } \\
\text { cutânea. }\end{array}$ & $\begin{array}{l}\text { Não houve } \\
\text { soroconversão. }\end{array}$ \\
\hline Brasil & Grangeiro et al. & 2019 & $\begin{array}{l}\text { A perda do acompanhamento } \\
\text { foi definida quando a usuária } \\
\text { não retornava para as visitas } \\
\text { de acompanhamento ou a fim } \\
\text { de realizar o teste rápido para } \\
\text { HIV. } \\
\text { A taxa de falta aos retornos de } \\
\text { acompanhamento foi de } \\
72,8 \% \text {. }\end{array}$ & $\begin{array}{l}\text { Não adesão: os condicionantes } \\
\text { para não adesão foram ser de cor } \\
\text { preta, fazer uso de álcool e drogas } \\
\text { e ter realizado a PEP em um } \\
\text { hospital de doenças infecciosas ou } \\
\text { em um ambulatório de HIV, em } \\
\text { relação às mulheres que } \\
\text { receberam a PEP em um CTA. }\end{array}$ & $\begin{array}{l}\text { O estudo não } \\
\text { relatou efeitos } \\
\text { colaterais. }\end{array}$ & $\begin{array}{l}\text { Não relatou } \\
\text { soroconversão. }\end{array}$ \\
\hline
\end{tabular}

Fonte: elaboração própria. 
Após a leitura dos artigos encontrados na revisão, verificou-se que não houve concordância sobre o modo de avaliar a adesão à PEP, seja em relação ao uso correto dos ARV, seja quanto aos retornos em consulta ou conclusão do protocolo de profilaxia. Em alguns estudos, não se estabeleceu um critério predeterminado para a adesão e não adesão à PEP (Mayer et al., 2017; Carneiro et al., 2018; Malinverni et al., 2018). Para avaliar o percentual de adesão, alguns estudos usaram o autorrelato sobre o uso dos ARV (Milinkovic et al.; Hugo et al., 2016; Valin et al., 2016; Mayer et al, 2017), a contagem de comprimidos (Mayer et al., 2012; Milinkovic et al., 2017) e informações de prontuários dos serviços de saúde ou de farmácias (Malinverni et al., 2016; Carneiro et al., 2018; Rasoolinejad et al., 2018). Ademais, outros estudos empregaram a realização de exames de sangue para averiguar os níveis de droga circulante no plasma e o rastreio de usuários que não retornaram aos serviços, por meio de ligação telefônica (Granjeiro et al., 2019, McAllister et al., 2017; Foster et al., 2015; Bogoch et al., 2014). Esses métodos foram usados separados ou concomitantemente.

Dos estudos que trouxeram critérios para estabelecer a adesão aos ARV, teve-se: os usuários do serviço de saúde respondiam sobre a tomada do medicamento por autorrelato, e eram considerados aderentes aqueles que não perdessem mais de 5 doses durante os 28 dias da PEP (Thomas et al., 2015); dois estudos aplicaram um questionário adaptado sobre a adesão ao medicamento, e nesse questionário o grau de adesão foi calculado com base nas respostas de cada usuário do serviço de saúde. Foram considerados não aderentes aqueles que ficaram com uma somatória final das respostas abaixo de 94\% (Inciarte et al., 2017; Leal et al., 2016); outro critério foi definir a adesão à PEP através do número de doses tomadas, por autorrelato, dividido pelo número total de doses prescritas. Nesse caso, se um participante deixasse de tomar três doses consecutivas do medicamento, não atingia a conclusão da PEP (Fletcher et al., 2013).

Em relação às taxas de adesão aos ARV, o seguimento e a conclusão da profilaxia, os estudos mostram que os usuários dos serviços começam a PEP seguindo regularmente a autoadministração dos ARV, mas vão reduzindo o uso com o passar do acompanhamento, implicando na não finalização da medida profilática (Carneiro et al., 2018; Bogoch et al., 2014). Também mostram que muitos usuários, mesmo considerados aderentes, a depender do critério de adesão adotado, não conseguem fazer o uso dos ARV por todos os dias (Bogoch et al., 2014; Carneiro et al., 2018; Foster et al., 2015; Hugo et al., 2016; Mayer et al., 2017). Em apenas um estudo, $91 \%$ dos usuários autorrelataram ter tomado os medicamentos nos 28 dias indicados (Noam Oz et al., 2017), já outros estudos mostraram uma porcentagem menor, com 27\% e 27,5\% (Carneiro et al., 2018; Mayer et al., 2012; Foster et al., 2015). 
Entre os fatores associados à adesão à PEP, estão: ser mais velho, ter maior nível de escolaridade, ser do sexo masculino, ter plano de saúde, ser abstinente de metanfetamina durante o período da profilaxia, descobrir que a pessoa com quem se relacionou teve resultados do teste rápido negativa para HIV, estar fazendo uso da PEP pela primeira vez, receber uma prescrição médica de ARV com menos comprimidos diários, existência de vínculo estabelecido com os profissionais de saúde, recebimento de orientações adequadas, acolhimento em um ambiente discreto para realizar o aconselhamento na consulta inicial e durante os retornos (Kahn et al., 2001; Landovitz et al., 2012; Bogoch et al., 2014; Thomas et al., 2015; Beymer et al., 2017; Malinverni et al., 2018).

Por outro lado, os meios que tendem a desfavorecer a adesão à PEP são: ser da cor preta, imigrante, não ter dinheiro para comprar os ARV, não possuir plano de saúde, estar doente (resfriado ou com anorexia), ter outras IST e exposições recorrentes sem proteção, fazer uso de álcool e drogas, sofrer efeitos adversos ao fazer uso dos ARV, ter realizado a PEP em um hospital de doenças infecciosas ou em um ambulatório de HIV, e não em um CTA (Malinverni et al., 2017; Granjeiro et al., 2019; Rasoolinejad et al., 2018; Beymer et al., 2017; Mayer et al., 2017; Fletcher et al., 2013). Em relação aos efeitos colaterais, nos estudos encontrados a maioria foi leve e moderada: dor abdominal, náusea, vômito, malestar, fadiga, diarreia e dor de cabeça (Foster et al., 2015; Hugo et al., 2016; Kahn et al., 2001; Mayer et al., 2012).

Desse modo, há uma demonstração de que, mesmo tendo retornado aos acompanhamentos dos serviços de saúde, não necessariamente houve adesão à PEP e de que a redução da adesão não está atrelada apenas a fazer ou não uso dos $\mathrm{ARV}$, mas a outros fatores condicionantes que determinam o uso dos medicamentos e o seguimento correto da profilaxia por parte dos usuários (Landovitz et al., 2012; Leal et al., 2016; Thomas et al., 2015).

Sobre a eficácia da PEP, a revisão mostra que poucos usuários soroconverteram, mas, quando há a soroconversão, geralmente ocorre porque eles tiveram outras exposições de risco durante a profilaxia e/ou baixa adesão aos ARV (Landovitz et al., 2012; Fletcher et al, 2013; Inciarte et al., 2017). Estudos que mostraram uma possível falha da PEP em usuários que relataram o uso correto do medicamento e não tiveram outras exposições de risco durante a profilaxia contaram com baixo percentual de soroconversão (Thomas et al., 2015; Malinverni et al., 2016). Um estudo, que observou 1.744 usuários do serviço de saúde a fazer uso da PEP, teve 17 soroconversões. Os usuários que soroconverteram relataram maior probabilidade de adesão incompleta aos ARV e o fato de terem iniciado a PEP depois do período de 72 horas após a suposta exposição ao HIV (Beymer et al., 2017). 
Dessa forma, é essencial que o usuário do serviço de saúde tenha acesso à PEP e que não se restrinja apenas a medida medicamentosa. É necessário que seja compreendida e aplicada como uma maneira, segundo Beymer et al. (2017), biocomportamental, em que é preciso entender os motivos da adesão e da não adesão para intervenções efetivas contra a infecção, resultando na efetividade da profilaxia, uma vez que a adesão diminui os riscos de uma possível soroconversão.

Em uma perspectiva da enfermagem em Saúde Coletiva, a adesão não é restrita ao comportamento específico do indivíduo; sua efetivação está condicionada ao pertencimento de classe ao qual o usuário pertence, o que pode culminar em potenciais de fortalecimento e desgastes que podem repercutir na adesão, ou seja, como entendem o processo saúde-doença, a inserção dos indivíduos na sociedade e se as necessidades de saúde estão sendo atendidas através do processo de produção dos serviços de saúde. Esses eixos podem ser colocados como potenciais para o cumprimento do projeto terapêutico (Bertolozzi, 2009).

Estudos mostram que há a necessidade de uma abordagem mais simplificada e de melhorias no uso da profilaxia, além da falta de compatibilidade entre as orientações prestadas e o que é preconizado pelos protocolos (Chunqing, 2008). O diálogo e o vínculo estabelecidos com o usuário são fundamentais para a adesão, uma vez que se tem um problema de estigma estrutural que pode ser reproduzido no processo de acompanhamento ao paciente a precisar de apoio, fato esse recorrente com $\mathrm{HSH}$, implicando em um fator importante que o torna menos aderente ao medicamento (Oldenburg, 2014).

Não basta que o usuário do serviço de saúde queira tomar os medicamentos; é preciso entender que a adesão depende de diversos condicionantes que estão ao redor da vida do indivíduo (Bertolozzi, 2009); também é preciso destacar a importância de alcançar todos os grupos populacionais, uma vez que a dificuldade de acesso tende a afetar os mais vulneráveis, como mulheres profissionais do sexo (Izulla, 2013), deixando-os mais expostos à infecção pelo HIV.

Portanto, a adesão à PEP é um elemento fundamental para diminuir a infecção pelo HIV. Reconhecendo a complexidade envolvida, é necessário analisar os condicionantes para que de fato ela ocorra. Por essa razão, justifica-se a realização deste estudo, além de ela levar à consideração de que há uma escassez de pesquisas sobre a temática, principalmente no Brasil.

Diante do exposto, e tendo por objeto deste estudo a adesão à PEP de risco à infecção pelo HIV por conta da exposição sexual, busca-se responder às seguintes questões:

- Quem são os usuários indicados para PEP de risco ao HIV devido à exposição sexual em um serviço de saúde no município de São Paulo? 
- Qual é o índice de adesão à PEP de risco ao HIV devido à exposição sexual em usuários de um serviço de saúde no município de São Paulo?

- Quais são os condicionantes para adesão à PEP de risco ao HIV? 


\section{HIPÓTESES}

Como hipóteses, tem-se que:

- a maioria dos usuários indicados para PEP de risco ao HIV devido à exposição sexual será de HSH, indivíduos de cor branca e escolarizados;

- a adesão à PEP de risco ao HIV devido à exposição sexual será entre 60\% e 70\%;

- serão condicionantes à adesão à PEP de risco ao HIV: cor, moradia, renda, benefícios de programas sociais, sexo, escolaridade e as condições da assistência de um serviço de saúde. 


\section{OBJETIVOS}

\subsection{OBJETIVO GERAL}

Analisar a adesão à PEP de risco ao HIV devido à exposição sexual em usuários de um serviço de atenção em HIV/aids do município de São Paulo, selecionados de 1 o de abril a 30 de agosto, com seguimento até 23 de outubro de 2019.

\subsection{OBJETIVOS ESPECÍFICOS}

1. Caracterizar os usuários indicados à PEP de risco ao HIV devido à exposição sexual;

2. Verificar a adesão dos usuários à PEP de risco ao HIV devido à exposição sexual; e

3. Avaliar condicionantes associados à adesão à PEP de risco ao HIV devido à exposição sexual, referidas as condições sociodemográficas, a inserção do indivíduo na sociedade e as condições da assistência do serviço de saúde. 


\section{MÉTODOS}

\subsection{TIPO DE ESTUDO}

Trata-se de um estudo de abordagem quantitativa, descritivo e analítico, do tipo coorte prospectivo. Os usuários foram selecionados de 1 을 de abril a 30 de agosto e seguidos até 23 de outubro de 2019.

\subsection{REFERENCIAL TEÓRICO-CONCEITUAL}

O conceito de vulnerabilidade inicia-se a partir de Mann (1993), no livro A Aids no mundo, e está ligado aos direitos humanos. Considerado um dos primeiros autores a fazer a relação entre saúde e direitos humanos no campo do HIV/aids, Jonathan Mann trouxe a possibilidade de que a epidemia da aids fosse interpretada a partir da vulnerabilidade (Mann et al., 1993). Em 1996, em uma nova edição do livro, observou-se avanços por conta da melhor compreensão dos aspectos estruturais que envolvem a epidemia da aids e da vinculação dos direitos humanos em relação à população mais exposta ao HIV (Ayres, 2018).

No Brasil, o conceito de vulnerabilidade ganhou força pelo fato de ter surgido em paralelo a importantes contextos políticos, como a reforma sanitária e a democratização do país (Ayres, 2018); ele teve maior destaque a partir do momento em que a compreensão da disseminação da aids e a interiorização da epidemia para os diferentes municípios, atingindo a camada mais pobre da população, além da infecção pelo HIV, já não poderiam ser explicadas por meio dos conceitos de grupo e comportamento de risco (Ayres et al., 2009). Segundo Paiva et al. (2002), superar as noções de comportamentos e grupos de risco em relação ao HIV/aids é um passo crucial para que se consiga analisar a trajetória da epidemia da doença.

Com a introdução do conceito da vulnerabilidade, foi possível entender que a exposição do indivíduo ao HIV e o adoecimento pela aids resultam de um conjunto de aspectos que não são apenas individuais, mas também coletivos e contextuais. Esses aspectos, juntos, influenciam a suscetibilidade à infecção ou ao adoecimento e, de maneira indivisível, para se proteger de ambos, implica na maior ou menor disposição de recursos (Ayres et al., 2009).

Nesse sentido, pode-se analisar a vulnerabilidade de um usuário do serviço de saúde a partir de três perspectivas: 1) individual, ou seja, o modo como as pessoas vivem contribui 
para uma exposição ou proteção ao vírus. Isso diz respeito ao conhecimento do usuário quanto às informações que se tem sobre a doença, como a forma de transmissão e características pessoais, por exemplo, sexo, raça e uso de drogas. Ademais, é sobre a capacidade de o usuário captar informações, introduzi-las em sua rotina e, a partir disso, converter suas preocupações em práticas de prevenção. 2) social, isto é, relaciona-se ao fato de que as mudanças práticas, por meio da aquisição de informação e da capacidade de assimilação, não dependem apenas dos usuários, mas também de acessos aos meios de comunicação, escolarização, decisões políticas, moradia, recursos materiais, entre outros. 3) programática, que remete aos esforços programáticos para que sejam disponibilizados recursos de que os indivíduos precisam, tanto para não se exporem ao HIV, como também para se protegerem de danos. Um desses recursos diz respeito aos serviços de saúde que, a depender da maneira como estão organizados, podem reproduzir, diminuir ou aumentar as condições de vulnerabilidade dos usuários dos serviços (Ayres et al., 2006).

Nesse sentido, pensar na atuação do serviço de saúde requer ações para além do individual, mas que possibilitam planejamento, organização e recursos humanos, de modo a proporcionar aos usuários um melhor enfrentamento da infecção pelo HIV e uma possibilidade de superação durante o período da PEP. Considerando que, segundo Nichiata (2008), o caminho que conduz o indivíduo à infecção não é apenas comportamental, as intervenções não podem ser baseadas em um único fator, mas em um olhar para a coletividade que as envolve.

Assim, a adesão aos ARV é essencial para a eficácia da profilaxia. Visto que a vulnerabilidade dos usuários do serviço de saúde pode ser um empecilho durante esse processo, impactando diretamente na adesão, buscou-se entender a vulnerabilidade a partir do olhar da Saúde Coletiva. Na perspectiva dessa área, entendendo a vulnerabilidade como um somatório de aspectos que vão além do individual, esse conceito é utilizado para ampliações mais concretas relacionadas às intervenções, de maneira a se estabelecer como um instrumento para práticas de saúde (Sanches e Bertolozzi, 2007).

A ampliação do conceito de vulnerabilidade proporciona o entendimento das necessidades de saúde dos usuários, pelo fato de que é possível agregar práticas relacionadas ao cuidado indivíduo-coletivo, apoiando os usuários quanto a suas garantias (Sanches e Bertolozzi, 2007). Nesse sentido, como referencial teórico que regerá a interpretação e a discussão dos resultados, será adotado o significado de adesão desenvolvido por Bertolozzi (2001: p. 136): 
pessoa, a organização dos processos de trabalho em saúde e a acessibilidade em sentido amplo, que inclui os processos que levam - ou não - ao desenvolvimento da vida com dignidade.

A adesão apresenta-se em três planos: individual, ou seja, como é o entendimento e o comportamento do indivíduo diante do processo de saúde; social, isto é, sua inserção na sociedade, o que determina, de fato, uma inserção mais precarizada no processo de produção e, consequentemente, no desenvolvimento da vida, ou seja, determina potenciais de fortalecimento e de desgaste peculiares aos grupos sociais específicos; e organizacional, que trata do processo de produção de serviços de saúde e da maneira de organização dos processos de trabalho (Bertolozzi et al., 2009).

A análise da adesão à PEP por uma possível exposição sexual ao HIV compreendeu: a caracterização sociodemográfica dos usuários indicados para PEP, a avaliação dos condicionantes presentes na adesão à PEP associada à inserção do indivíduo na sociedade e as condições da assistência em um serviço de atenção especializada (SAE) HIV/aids.

\subsection{CENÁRIO DO ESTUDO}

O estudo foi realizado no município de São Paulo, em um SAE HIV/aids. Os SAE HIV/aids são de responsabilidade técnica do Programa Municipal de DST/aids, da Secretaria Municipal de Saúde, e de responsabilidade administrativa das Coordenadorias de Saúde (CRS). Há seis coordenadorias: Centro, Sul, Oeste, Norte, Sudeste e Leste. Todas as CRS possuem SAE em IST e HIV/aids: um na CRS Centro, quatro na CRS Sul, dois na CRS Oeste, um na CRS Norte, dois na CRS Sudeste e dois na CRS Leste (Figura 5). 
Figura 5. Coordenadorias de Saúde do município de São Paulo - 2019.

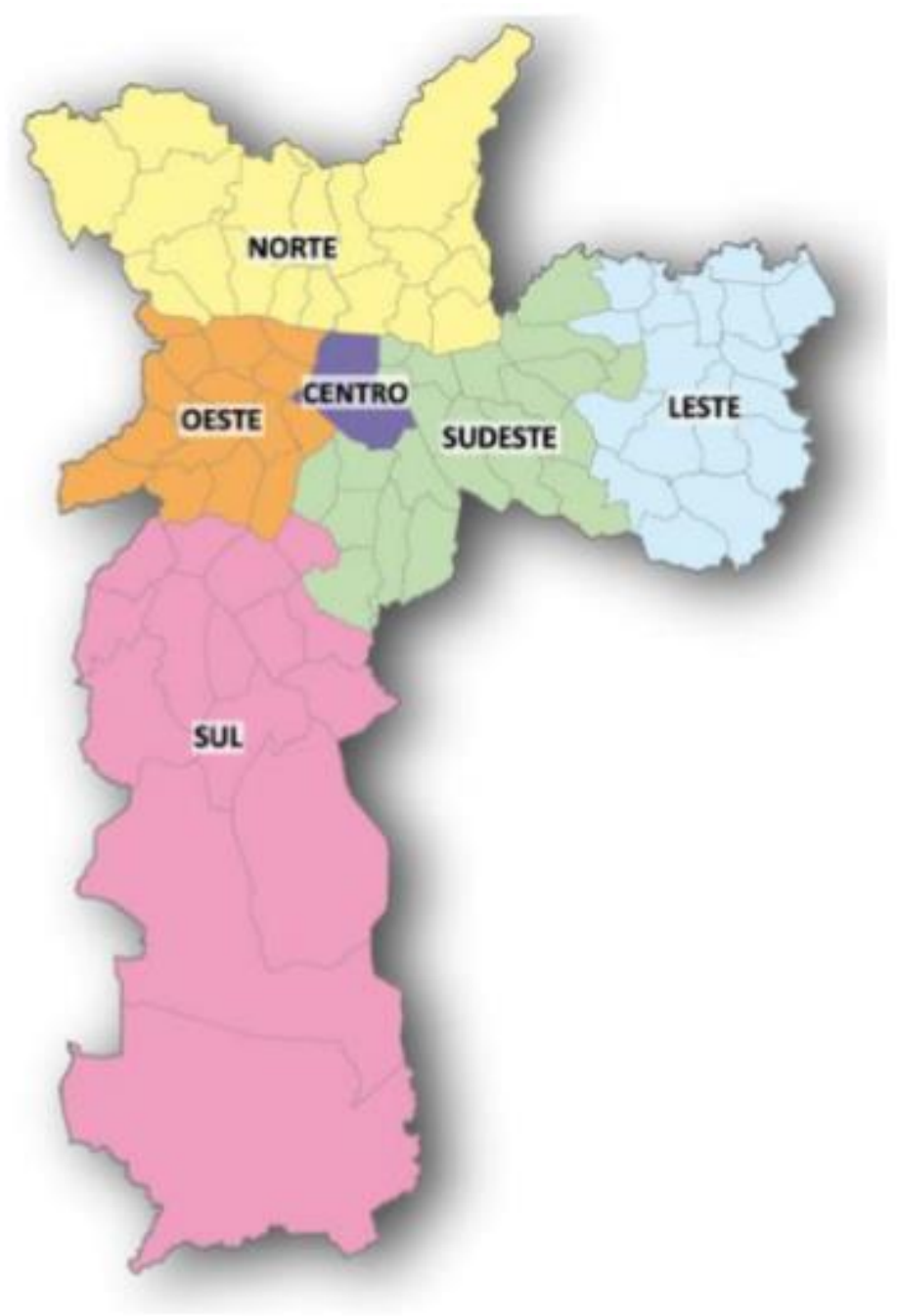

Fonte:

https://www.prefeitura.sp.gov.br/cidade/secretarias/saude/organizacao/coordenadorias_saude/index.php?p=65 41

O SAE tem como objetivo a prevenção do HIV/aids de maneira integral e com qualidade por meio de atendimento da equipe multiprofissional (enfermeiros, médicos, farmacêuticos, nutricionistas, assistentes sociais, psicólogos, entre outros) e desempenha atividades específicas, como: atendimento em infectologia e ginecológico, controle e distribuição de ARV, orientações farmacêuticas, realização de exames de monitoramento, distribuição de insumos de prevenção, atividades educativas para adesão à profilaxia e prevenção e controle de IST/aids, orientação e apoio psicológico (São Paulo, 2018).

A PEP ao HIV é distribuída nos SAE e em outros serviços de saúde especializados, que são os CTA, os CR, as AMA, alguns hospitais, PS, PA e Unidade de Pronto Atendimento (UPA), espalhados por todas as regiões do município de São Paulo. Entretanto, alguns serviços não realizam o seguimento dos usuários após a indicação da PEP; é efetuado um primeiro atendimento e a dispensação da PEP, e os usuários do serviço de saúde são 
orientados a seguirem com a profilaxia em um serviço de referência ao HIV (São Paulo, 2018). No Quadro 3, ilustra-se a distribuição dos serviços de saúde que oferecem a PEP ao HIV e os que fazem o seguimento.

Quadro 3. Distribuição dos serviços de saúde que oferecem a PEP ao HIV no município de São Paulo. São Paulo, 2018.

\begin{tabular}{|c|c|c|}
\hline $\begin{array}{l}\text { Coordenadorias } \\
\text { Regionais de } \\
\text { Saúde }\end{array}$ & $\begin{array}{l}\text { Serviços que realizam o } \\
\text { primeiro atendimento e o } \\
\text { seguimento da PEP ao HIV } \\
\text { com funcionamento de } \\
\text { segunda a sexta, das } 7 \mathrm{~h} \text { às } 19 \mathrm{~h}\end{array}$ & $\begin{array}{l}\text { Serviços que realizam apenas o } \\
\text { primeiro atendimento da PEP } \\
\text { ao HIV com funcionamento em } \\
\text { todos os dias }(24 \mathrm{~h})\end{array}$ \\
\hline Centro & $\begin{array}{l}\text { CTA Henfil (Henrique de } \\
\text { Souza Filho; } \\
\text { SAE DST/aids Campos Elíseos }\end{array}$ & $\begin{array}{l}\text { AMA Sé; } \\
\text { PS Barra Funda }\end{array}$ \\
\hline Sudeste & $\begin{array}{l}\text { SAE CECI; } \\
\text { SAE Vila Prudente; } \\
\text { CR Penha; } \\
\text { SAE Herbert de Souza; } \\
\text { SAE Joé Francisco de Araújo; } \\
\text { CTA Mooca }\end{array}$ & $\begin{array}{l}\text { AMA Hospitalar Saboya; } \\
\text { UPA Santa Catarina; } \\
\text { AMA Hospitalar Proença de } \\
\text { Gouveia; } \\
\text { PS Augusto Gomes de Matos; } \\
\text { Hospital Benedito Montenegro; } \\
\text { AMA Doutor Carmino Caricchio; } \\
\text { AMA Hospitalar Alexandre Zaio }\end{array}$ \\
\hline Norte & $\begin{array}{l}\text { CR Nossa Senhora do Ó; } \\
\text { CTA Pirituba; } \\
\text { SAE Marcos Lottemberg; } \\
\text { CTA Pirituba }\end{array}$ & $\begin{array}{l}\text { PS Santana-Lauro Ribas Braga; } \\
\text { PS Vila Maria baixa; } \\
\text { Hospital Municipal São Luiz } \\
\text { Gonzaga; } \\
\text { Hospital Municipal Vila Maria; } \\
\text { Hospital Municipal Dr. José; } \\
\text { Soares Hungria } \\
\text { Hospital Municipal } \\
\text { Maternidade Escola Dr. Mário } \\
\text { Silva; } \\
\text { PS Municipal } 21 \text { de Junho }\end{array}$ \\
\hline Oeste & $\begin{array}{l}\text { SAE DST/aids Butantã; } \\
\text { SAE Paulo Cesar Bonfim/Lapa }\end{array}$ & $\begin{array}{l}\text { AMA Sorocabana; } \\
\text { PS Municipal da Lapa; } \\
\text { Instituto de Infectologia Emílio } \\
\text { Ribas; } \\
\text { AMA Paraisópolis }\end{array}$ \\
\hline Sul & $\begin{array}{l}\text { SAE Santo Amaro; } \\
\text { CTA Santo Amaro; } \\
\text { CR Santo Amaro; } \\
\text { SAE Jardim Mitsutani/CTA; } \\
\text { SAE Cidade Dutra; } \\
\text { SAE M'BOI Mirim; } \\
\text { Ambulatório de Infectologia da } \\
\text { Unifesp; } \\
\text { CRT Vila Mariana; }\end{array}$ & $\begin{array}{l}\text { PS Municipal Balneário São José; } \\
\text { UPA Campo Limpo; } \\
\text { Hospital Municipal Dr. Fernando } \\
\text { Mauro Pires da Rocha; } \\
\text { Hospital Municipal Dr. Moyses } \\
\text { Deustsch; } \\
\text { AMA } 24 \text { horas Paraisópolis; } \\
\text { AMA } 24 \text { horas Capão Redondo; } \\
\text { AMA } 24 \text { horas Parelheiros; } \\
\text { PA JD Macedônia; }\end{array}$ \\
\hline
\end{tabular}




\begin{tabular}{|l|l|l|}
\hline & & $\begin{array}{l}\text { PS Santo Amaro - José Silvio de } \\
\text { Camargo; } \\
\text { PS Grajaú - Maria Antonieta F } \\
\text { Barros; } \\
\text { PS Balneário São José; } \\
\text { UPA Santo Amaro }\end{array}$ \\
& & $\begin{array}{l}\text { PS Municipal Júlio Tupy; } \\
\text { PA São Mateus; }\end{array}$ \\
\hline Leste & CTA Cidade Tiradentes; & Hospital Municipal Dr. Alípio \\
& CTA Dr. Sérgio Arouca; & PA Glória Rodrigues dos Santos \\
& CTA São Mateus; & Bonfim; \\
& CTA São Miguel; & PA Dr. Atualpa Girão Rabelo; \\
& CTA Guaianases; & AMA Tide Setubal; \\
& SAE Cidade Líder II; & AMA Waldomiro de Paula \\
& SAE Fidélis Ribeiro &
\end{tabular}

Fonte: São Paulo, 2014.

O presente estudo foi realizado em um SAE da região central do município. A escolha por esse serviço deve-se ao fato de que está inserido em uma região de vulnerabilidade social, com concentração de albergues, moradores de rua, localidade de usuários de drogas, áreas de prostituição, onde é alta a taxa de detecção de aids na cidade, conforme apresentado anteriormente. É um serviço que recebe um alto fluxo de pessoas para PEP no município, com expertise no atendimento de PEP e de pessoas que vivem com HIV. Possui funcionamento de segunda a sexta feira, das $7 \mathrm{~h}$ às $19 \mathrm{~h}$, com maior demanda para PEP nas segundas e terças-feiras. O fluxo de atendimento do serviço de saúde durante a pesquisa procedeu da seguinte forma:

1. O usuário que chegava por demanda espontânea ao serviço (na recepção) era encaminhado para o acolhimento, realizado por equipe multiprofissional (psicólogos, assistentes sociais, enfermeiros, educador de saúde, entre outros). Eram esclarecidas dúvidas sobre a exposição ao HIV e outras IST. Após o aconselhamento, o usuário era encaminhado a uma sala para realização de testes rápidos (HIV, sífilis, hepatites B e C) por um profissional capacitado e aguardava o resultado. Os que chegavam encaminhados por outros serviços passavam apenas pela recepção e pelo aconselhamento.

2. O usuário retornava ao aconselhamento para recebimento do resultado por um aconselhador, que poderia ser um enfermeiro, psicólogo ou assistente social capacitado. Caso o resultado fosse negativo para HIV, era indicada a PEP. Dúvidas sobre o uso do medicamento eram esclarecidas pelo profissional aconselhador, que podia encaminhá-lo ao médico para consulta e prescrição dos medicamentos. 
3. O usuário retirava os antirretrovirais para posologia de 28 dias na dispensação de medicamentos do serviço de saúde e iniciava a profilaxia. O seguimento ocorria em dois retornos do usuário ao serviço de saúde, com 30 e 90 dias após o primeiro atendimento. Nesses dois retornos, eram realizados testes rápidos para identificação de uma possível soroconversão para o HIV e presença de outras IST.

\subsection{POPULAÇÃO DO ESTUdO E CRITÉRIOS DE INCLUSÃO E EXCLUSÃO}

Critério de inclusão: o estudo elegeu como população usuários do SAE HIV/aids indicados para PEP devido à exposição sexual. Foram excluídos usuários menores de 18 anos, com indicação de PEP ocupacional e situações que envolveram violência sexual. A amostra foi tomada por conveniência. Para o seguimento da coorte foram considerados quatro meses, sendo elegíveis 91 participantes da pesquisa.

\subsection{INSTRUMENTOS DE COLETA}

Para o presente estudo foi construído um questionário sobre as características sociodemográficas, formas de viver, formas de trabalhar, processo de saúde e atendimento do serviço de saúde (Apêndice 1), elaborado com questões baseadas na literatura e fundamentado no SI-DST Aids-Módulo de Diagnóstico Sorológico (questionário utilizado pelo serviço de saúde) (Anexo 1) e no instrumento "Cuestionario para la Evaluación de la Adhesión al Tratamiento Antirretroviral” - CEAT/VIH (Remor et al., 2007) (Anexo 2).

As variáveis "recebe benefício social" e "o serviço de saúde atendeu às necessidades" foram exploradas de maneira diferente nos resultados devido ao baixo número de usuários participantes do estudo. Na associação com a adesão, foi explorado apenas se o usuário recebia ou não algum benefício social e se o serviço de saúde atendeu ou não a necessidades dele. Além disso, na descritiva foi explorado quais eram os benefícios recebidos pelos usuários, e também os motivos pelos quais o serviço de saúde atendeu às necessidades. Por fim, a variável cultura foi composta pela somatória das respostas dos usuários em relação ao acesso à internet, a livros e a revistas.

Ademais, para as análises dos dados, foram realizadas algumas alterações de categorização das variáveis: raça autorreferida (Branca, Preta, Parda, Amarela/Indígena); escolaridade (Ensino Fundamental/Médio, Ensino Superior/Pós-Graduação); local de moradia (Município de São Paulo, Fora do município de São Paulo); orientação sexual 
(Heterossexual, HSH, Bissexual); domicílio (Próprio, Alugado, Ocupação/Albergue); com quem mora ( $0 ; 1 ; 2 ; 3 ; \geq 4$ pessoas); chefe da família (Próprio usuário, Familiares/Amigos); onde teve acesso ao preservativo (Público, comprou na farmácia, Público ou comprou na farmácia); como obteve informação sobre a PEP (Equipe de saúde, Propaganda sobre a PEP, Buscou informação sobre a PEP, Amigos); tipo de serviço em que iniciou a PEP (SAE, AMA, Emílio Ribas). As variáveis são descritas no Quadro 5.

Ao final, o questionário construído para a presente pesquisa conteve 68 questões abertas e fechadas distribuídas em cinco blocos: características sociodemográficas (1-14), formas de viver (15-22), formas de trabalhar (23-28), processos de saúde (29-63) e atendimento do serviço de saúde (64-68) (Apêndice 1). O preenchimento do instrumento foi realizado por meio de entrevista pelo próprio pesquisador.

As questões sobre as características sociodemográficas, formas de trabalhar e formas de viver foram aplicadas apenas na baseline (primeiro encontro). As questões sobre o processo de saúde e o atendimento do serviço de saúde foram aplicadas no dia da indicação da PEP (baseline) e nos dois retornos - no momento 1 (30 dias após a indicação da PEP) e no momento 2 (90 dias após a indicação da PEP) -, conforme o Quadro 4.

Quadro 4. Distribuição das questões que foram aplicadas na baseline, no momento 1 e no momento 2 .

\begin{tabular}{|c|c|c|c|c|c|}
\hline & $\begin{array}{c}\text { Baseline } \\
\text { (Questões) }\end{array}$ & $\begin{array}{c}\text { Momento } \\
1 \\
\text { (Questões) }\end{array}$ & $\begin{array}{c}\text { Momento } \\
2 \\
\text { (Questões) }\end{array}$ & $\begin{array}{c}\text { Momento } 1 \\
\text { e momento } \\
2 \\
\text { (Questões) }\end{array}$ & $\begin{array}{l}\text { Baseline, } \\
\text { momento } \\
1 \mathrm{e} \\
\text { momento } \\
2\end{array}$ \\
\hline $\begin{array}{l}\text { Características } \\
\text { sociodemográficas }\end{array}$ & $1-14$ & - & - & - & - \\
\hline Formas de viver & $15-22$ & - & - & - & - \\
\hline $\begin{array}{l}\text { Formas de } \\
\text { trabalhar }\end{array}$ & $23-28$ & - & - & - & - \\
\hline Processo de saúde & $\begin{array}{l}29-41,46-49, \\
51-52,56,60\end{array}$ & $\begin{array}{r}53-55,57- \\
58\end{array}$ & - & 59 & $42-45,50$ \\
\hline $\begin{array}{l}\text { Atendimento do } \\
\text { serviço }\end{array}$ & 64,68 & - & - & - & $65-67$ \\
\hline
\end{tabular}

Fonte: elaboração própria. 
O instrumento foi testado durante uma semana com os seis primeiros usuários do serviço de saúde. Esse teste-piloto teve como objetivo avaliar a aplicabilidade e a eficácia do instrumento para realizar possíveis ajustes na composição e na estruturação das perguntas. Foi observado que algumas questões que seriam realizadas apenas no baseline poderiam ser feitas, também, nos retornos de acompanhamentos. Essas questões foram: sobre o atendimento do usuário no serviço de saúde; sobre o tempo de permanência do usuário no serviço de saúde, sobre a exposição sexual e sobre o processo de saúde; se o usuário teve outras exposições e quais foram os tipos dessas exposições durante o período da PEP. Como não houve modificações nas questões aplicadas no baseline, as informações obtidas no testepiloto foram computadas aos dados gerais do estudo.

\subsection{COLETA DE DADOS}

Antes do início da coleta, foi feita uma reunião no serviço de saúde para apresentar o projeto, conhecer os profissionais de referência e verificar as condições de estrutura física da sala em que seriam realizadas as entrevistas, atentando-se para a privacidade dos entrevistados.

Durante a coleta, o pesquisador convidou os usuários que corresponderam aos critérios de inclusão, apresentou a pesquisa e explicou sobre o Termo de Consentimento Livre e Esclarecido (TCLE) (Apêndice 2). Todos os usuários que concordaram em participar da pesquisa assinaram o TCLE. A participação na pesquisa foi oferecida para 97 usuários, e 6 se recusaram a participar por alegarem estar atrasados para o trabalho.

A coleta foi realizada no período de 1 de abril a 23 de outubro de 2019 e foi conduzida da seguinte forma:

1) Entrevista junto aos usuários do serviço, de acordo com o instrumento, por contato pessoal ou por telefone (quando o usuário não retornou e cujo contato telefônico teve sucesso).

2) As entrevistas foram realizadas no baseline, no momento 1 e no momento 2.

3) Como o período de inclusão dos usuários no estudo teve duração de quatro meses (abril a julho), o baseline, o momento 1 e o momento 2 ocorreram de maneira concomitante em alguns meses, conforme a Figura 6. 
Figura 6. Período das entrevistas em relação ao acompanhamento do usuário no baseline, no momento 1 e no momento 2 .

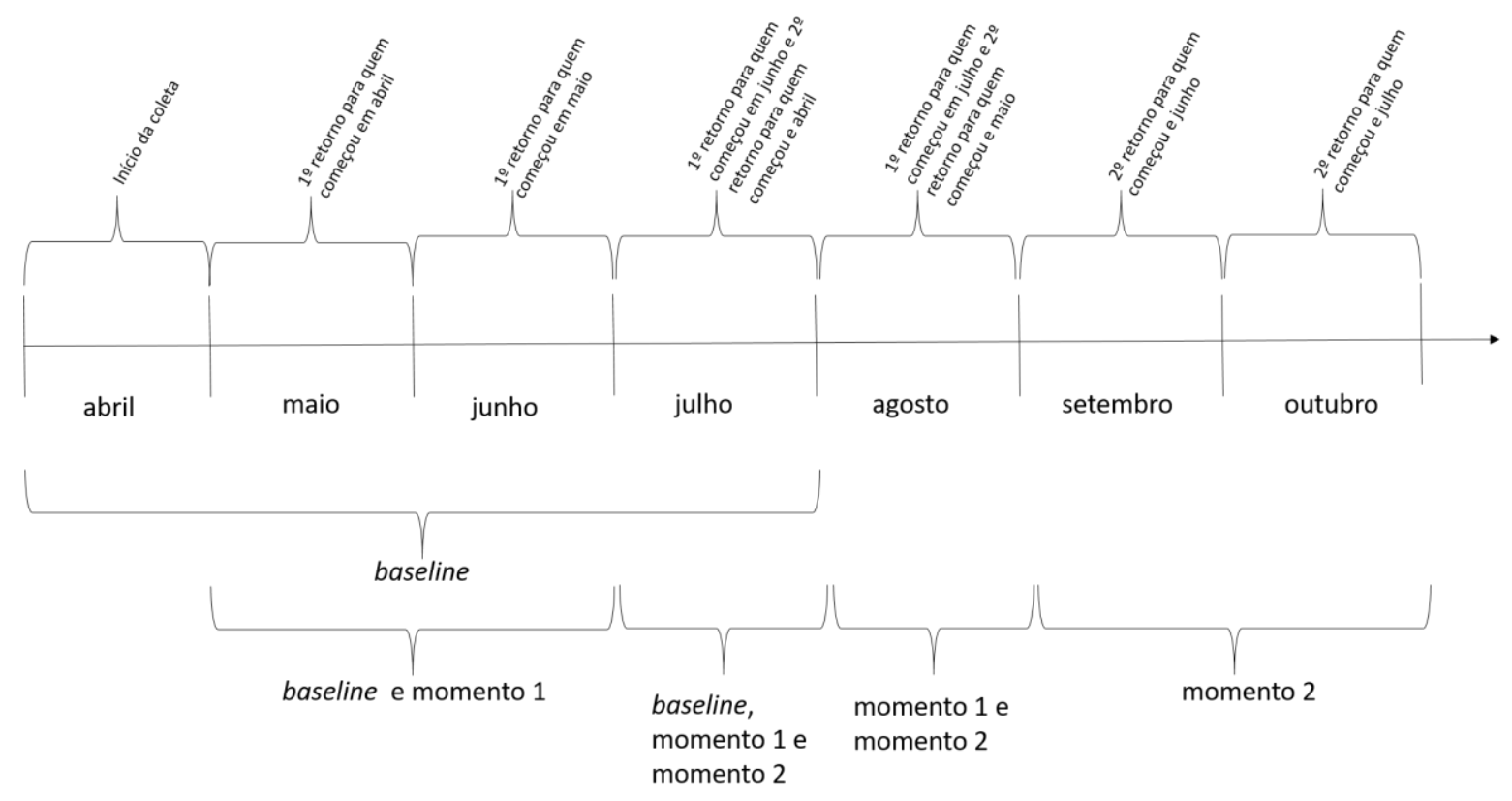

Fonte: elaboração própria.

No baseline, foram coletados dados sobre as questões relacionadas às características sociodemográficas, às formas de trabalhar, às formas de viver, ao processo de saúde e ao atendimento do serviço de saúde. Esses dados foram compilados no software Excel.

No momento 1 e no momento 2 , foram coletados dados sobre questões relacionadas ao processo de saúde e ao atendimento do serviço. Para os usuários que não retornaram e cujo contato telefônico teve sucesso, foram realizadas a entrevista por telefone e uma questão sobre os motivos da ausência à consulta.

\subsection{VARIÁVEIS DE ESTUDO}

\subsubsection{Variável dependente}

A variável dependente foi adesão à PEP. Na literatura, não foi encontrado consenso sobre o critério de adesão à PEP. Os estudos adotam diferentes maneiras, tanto em relação à tomada do medicamento como ao retorno ao serviço de saúde. Inicialmente, a ideia era adotar o seguinte critério: usuário que tivesse tomado todo o medicamento ( 28 dias) e voltado ao serviço nos dois retornos - 30 e 90 dias, momento 1 e momento 2, respectivamente - seria considerado aderente. Apenas 7 usuários cumpriram o critério dos dois retornos e, entre eles, de um usuário não foi possível captar a informação sobre a tomada do medicamento, uma 
vez que o pesquisador não estava presente no momento do retorno. Dessa maneira, o índice de adesão seria de apenas $12 \%$ (dados não apresentados em tabela).

Dessa maneira, optou-se por estabelecer como critério de adesão à PEP a condição de que o usuário tenha tomado o medicamento e retornado ao menos uma vez, no momento 1 ou no momento 2 (Tabela 1). Usuários que deixaram de tomar o medicamento por apenas um dia foram considerados aderentes em relação ao uso dos ARV.

Nesse sentido, segundo os critérios adotados, a variável dependente foi a adesão à PEP, que obteve índice de $56,7 \%$.

Tabela 1. Adesão à PEP devido à exposição sexual ao HIV segundo as variáveis medicamento e, ao menos, um retorno no momento 1 ou no momento 2. São Paulo, 2019.

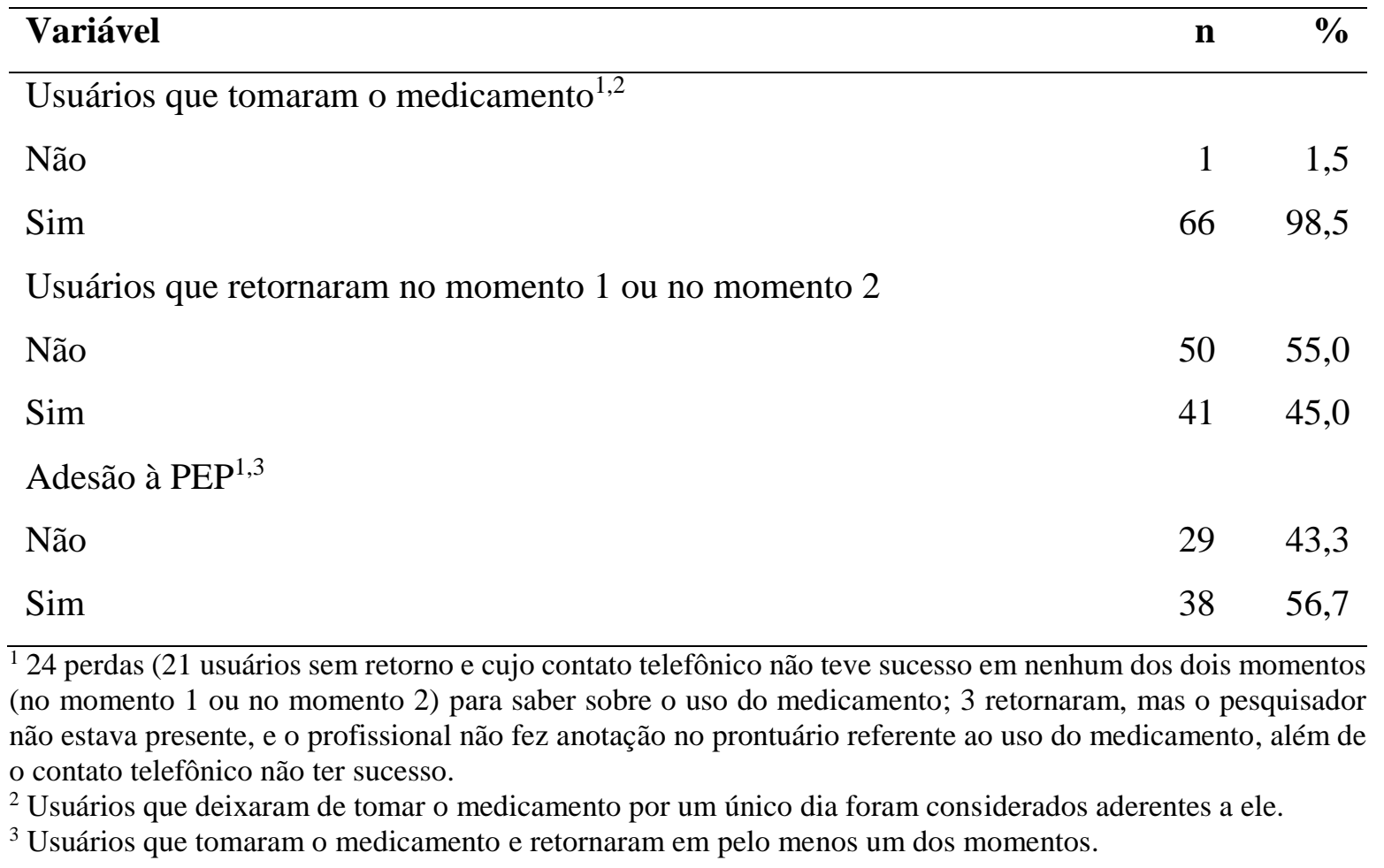

\subsubsection{Variáveis independentes}

No Quadro 5 são apresentadas as variáveis independentes do presente estudo, bem como a descrição e as categorias. 
Quadro 5. Descrição das variáveis independentes.

\begin{tabular}{|c|c|c|}
\hline Variáveis & Descrição & Categorias \\
\hline Idade & Idade do usuário & Em anos $(15-24 ; 25-44 ; \geq 45)$ \\
\hline Sexo & Sexo do usuário & Masculino, Feminino \\
\hline Raça (autorreferida) & $\begin{array}{l}\text { Raça autorreferida pelo } \\
\text { usuário }\end{array}$ & $\begin{array}{l}\text { Branca, Preta, Parda, } \\
\text { Amarela/Indígena }\end{array}$ \\
\hline Escolaridade & Escolaridade do usuário & $\begin{array}{l}\text { Ensino } \quad \text { Fundamental/Médio, } \\
\text { Ensino Superior/Pós-Graduação }\end{array}$ \\
\hline Local de moradia & Local de moradia do usuário & $\begin{array}{l}\text { São Paulo (município), Fora de São } \\
\text { Paulo (município) }\end{array}$ \\
\hline Com quem mora & Com quem o usuário mora & $\begin{array}{l}\text { Com companheiro(a), Sozinho(a), } \\
\text { Com outras pessoas }\end{array}$ \\
\hline Orientação sexual & $\begin{array}{l}\text { A orientação sexual do } \\
\text { usuário }\end{array}$ & Heterossexual, HSH, Bissexual \\
\hline Trabalha no momento & Se o usuário trabalha & Não/Sim \\
\hline Registro em carteira & $\begin{array}{l}\text { Se o usuário tem registro em } \\
\text { carteira }\end{array}$ & Não/Sim \\
\hline $\begin{array}{l}\text { Curso preparatório } \\
\text { para o trabalho }\end{array}$ & $\begin{array}{l}\text { Se o usuário, quando chefe de } \\
\text { família, tem curso } \\
\text { preparatório para o trabalho }\end{array}$ & Não/Sim \\
\hline $\begin{array}{l}\text { Classificação da } \\
\text { ocupação }\end{array}$ & $\begin{array}{l}\text { Classificação da ocupação do } \\
\text { usuário }\end{array}$ & $\begin{array}{l}\text { Profissional do sexo, Planejamento } \\
\text { e organização, Empresário, direção } \\
\text { e gerência, Não qualificado na } \\
\text { execução, Semiqualificado na } \\
\text { execução, Qualificado na } \\
\text { execução, Serviços gerais, Não } \\
\text { operacional/apoio }\end{array}$ \\
\hline $\begin{array}{l}\text { Recebe benefício } \\
\text { vale-transporte }\end{array}$ & $\begin{array}{l}\text { Se o usuário recebe vale- } \\
\text { transporte }\end{array}$ & Não/Sim \\
\hline $\begin{array}{l}\text { Recebe benefício } \\
\text { cesta básica }\end{array}$ & $\begin{array}{l}\text { Se o usuário recebe cesta } \\
\text { básica }\end{array}$ & Não/Sim \\
\hline $\begin{array}{l}\text { Recebe benefício } \\
\text { plano de saúde }\end{array}$ & $\begin{array}{l}\text { Se o usuário recebe plano de } \\
\text { saúde }\end{array}$ & Não/Sim \\
\hline $\begin{array}{l}\text { Recebe benefício } \\
\text { vale-refeição }\end{array}$ & $\begin{array}{l}\text { Se o usuário recebe vale- } \\
\text { refeição }\end{array}$ & Não/Sim \\
\hline $\begin{array}{l}\text { Características do } \\
\text { domicílio }\end{array}$ & $\begin{array}{l}\text { Características do domicílio } \\
\text { onde o usuário mora }\end{array}$ & $\begin{array}{l}\text { Próprio, } \\
\text { Ocupação/Albergue }\end{array}$ \\
\hline $\begin{array}{l}\text { Paga Imposto Predial } \\
\text { e Territorial Urbano } \\
\text { (IPTU) }\end{array}$ & Se o usuário paga IPTU & Não/Sim \\
\hline $\begin{array}{l}\text { Número de pessoas } \\
\text { com quem mora }\end{array}$ & $\begin{array}{l}\text { Número de pessoas com } \\
\text { quem o usuário mora }\end{array}$ & Número de pessoas $(0 ; 1 ; 2 ; 3 ; \geq 4)$ \\
\hline
\end{tabular}




\begin{tabular}{|c|c|c|}
\hline Variáveis & Descrição & Categorias \\
\hline Chefe da família & $\begin{array}{l}\text { Quem é o chefe da família do } \\
\text { usuário }\end{array}$ & $\begin{array}{l}\text { Próprio } \\
\text { Familiares/Amigos }\end{array}$ \\
\hline Crença religiosa & $\begin{array}{l}\text { Se o usuário tem alguma } \\
\text { crença religiosa }\end{array}$ & Não/Sim \\
\hline $\begin{array}{l}\text { Suficiência da renda } \\
\text { para }\end{array}$ & $\begin{array}{l}\text { Se a renda do usuário é } \\
\text { suficiente para }\end{array}$ & $\begin{array}{l}\text { Alimentação, Lazer, Escola, } \\
\text { Vestuário, Saúde, Transporte, } \\
\text { Cultura }\end{array}$ \\
\hline $\begin{array}{l}\text { Recebe benefício } \\
\text { social }\end{array}$ & $\begin{array}{l}\text { Se o usuário recebe benefício } \\
\text { social }\end{array}$ & Não/Sim \\
\hline Quais benefícios & $\begin{array}{l}\text { Quais benefício social o } \\
\text { usuário recebe }\end{array}$ & Questão aberta \\
\hline $\begin{array}{l}\text { Participação em } \\
\text { grupos }\end{array}$ & $\begin{array}{l}\text { Se o usuário tem participação } \\
\text { em grupos }\end{array}$ & Não/Sim \\
\hline $\begin{array}{l}\text { De quais grupos } \\
\text { participa }\end{array}$ & $\begin{array}{l}\text { De quais grupos o usuário } \\
\text { participa }\end{array}$ & $\begin{array}{l}\text { Amigos de bairro, Grupo no local } \\
\text { de trabalho, Trabalho voluntário, } \\
\text { Grupo em igreja }\end{array}$ \\
\hline $\begin{array}{l}\text { Tratamento de IST } \\
\text { anterior }\end{array}$ & $\begin{array}{l}\text { Onde o usuário fez } \\
\text { tratamento de IST anterior }\end{array}$ & $\begin{array}{l}\text { Serviço de saúde, Automedicação, } \\
\text { Não tratou }\end{array}$ \\
\hline $\begin{array}{l}\text { Qual foi a IST } \\
\text { anterior }\end{array}$ & $\begin{array}{l}\text { Qual IST anterior o usuário } \\
\text { adquiriu }\end{array}$ & Questão aberta \\
\hline $\begin{array}{l}\text { Uso de drogas no } \\
\text { momento }\end{array}$ & $\begin{array}{l}\text { Se o usuário faz uso drogas } \\
\text { no momento }\end{array}$ & Não/Sim \\
\hline $\begin{array}{l}\text { Realizou teste } \\
\text { anterior do teste } \\
\text { rápido para HIV }\end{array}$ & $\begin{array}{l}\text { Se o usuário realizou teste } \\
\text { anterior para HIV }\end{array}$ & Não/Sim \\
\hline $\begin{array}{l}\text { Tempo da última } \\
\text { exposição ao HIV } \\
\text { (horas) }\end{array}$ & $\begin{array}{l}\text { Tempo da exposição de risco } \\
\text { ao HIV até sua chegada ao } \\
\text { serviço de saúde }\end{array}$ & Em horas $(\leq 24 ; 25 \dashv 48 ; 49 \dashv 72)$ \\
\hline $\begin{array}{l}\text { Uso de preservativo } \\
\text { nas relações sexuais }\end{array}$ & $\begin{array}{l}\text { Se o usuário faz uso de } \\
\text { preservativo nas relações } \\
\text { sexuais }\end{array}$ & Não/Sim \\
\hline $\begin{array}{l}\text { Teve acesso a } \\
\text { preservativo no } \\
\text { último ano }\end{array}$ & $\begin{array}{l}\text { Se o usuário teve acesso a } \\
\text { preservativo no último ano }\end{array}$ & Não/Sim \\
\hline $\begin{array}{l}\text { Serviço de saúde que } \\
\text { disponibilizou o } \\
\text { preservativo }\end{array}$ & $\begin{array}{l}\text { Em qual serviço de saúde o } \\
\text { usuário teve acesso ao } \\
\text { preservativo }\end{array}$ & $\begin{array}{l}\text { Público, Comprou na farmácia, } \\
\text { Público ou comprou na farmácia }\end{array}$ \\
\hline $\begin{array}{l}\text { Como obteve } \\
\text { informação sobre a } \\
\text { PEP }\end{array}$ & $\begin{array}{l}\text { Como o usuário obteve } \\
\text { informação sobre a PEP }\end{array}$ & $\begin{array}{l}\text { Equipe de saúde, Propaganda sobre } \\
\text { a PEP, Buscou informação sobre a } \\
\text { PEP, Amigos }\end{array}$ \\
\hline $\begin{array}{l}\text { Número de vezes em } \\
\text { que fez uso da PEP }\end{array}$ & $\begin{array}{l}\text { Número de vezes em que o } \\
\text { usuário fez uso da PEP }\end{array}$ & Em vezes $(1 ; 2 ; \geq 3)$ \\
\hline
\end{tabular}




\begin{tabular}{|c|c|c|}
\hline Variáveis & Descrição & Categorias \\
\hline $\begin{array}{l}\text { Tipo de prática sexual } \\
\text { que indicou a PEP }\end{array}$ & $\begin{array}{l}\text { Tipo de prática sexual pela } \\
\text { qual o usuário de saúde foi } \\
\text { indicado para a PEP }\end{array}$ & Anal ou vaginal, Oral \\
\hline $\begin{array}{l}\text { Uso de preservativo } \\
\text { na prática sexual que } \\
\text { indicou a PEP }\end{array}$ & $\begin{array}{l}\text { Se o usuário fez uso de } \\
\text { preservativo na prática sexual } \\
\text { que indicou a PEP }\end{array}$ & Não/Sim \\
\hline $\begin{array}{l}\text { Conhecimento sobre a } \\
\text { transmissão do HIV }\end{array}$ & $\begin{array}{l}\text { Se o usuário tem algum } \\
\text { conhecimento sobre a } \\
\text { transmissão do HIV }\end{array}$ & Questão aberta \\
\hline \begin{tabular}{llr}
\multicolumn{3}{c}{ Conhecimento sobre o } \\
que o & HIV & pode \\
causar & no & corpo \\
humano & &
\end{tabular} & $\begin{array}{l}\text { Se o usuário tem algum } \\
\text { conhecimento sobre o que o } \\
\text { HIV pode causar no corpo } \\
\text { humano }\end{array}$ & Questão aberta \\
\hline $\begin{array}{l}\text { Por que motivos você } \\
\text { não voltou ao serviço } \\
\text { de saúde? }\end{array}$ & $\begin{array}{l}\text { Os motivos pelos quais o } \\
\text { usuário não retornou ao } \\
\text { serviço de saúde }\end{array}$ & $\begin{array}{l}\text { Questão aberta (realizada por } \\
\text { telefone) }\end{array}$ \\
\hline $\begin{array}{l}\text { Em qual serviço de } \\
\text { saúde iniciou a PEP }\end{array}$ & $\begin{array}{l}\text { Em qual serviço de saúde o } \\
\text { usuário iniciou a PEP }\end{array}$ & Questão aberta \\
\hline $\begin{array}{l}\text { Tipo de serviço de } \\
\text { saúde que iniciou a } \\
\text { PEP }\end{array}$ & $\begin{array}{l}\text { O tipo de serviço de saúde no } \\
\text { qual o usuário iniciou a PEP }\end{array}$ & SAE, AMA, Emílio Ribas \\
\hline $\begin{array}{l}\text { Fez uso do } \\
\text { medicamento } \\
\text { diariamente }\end{array}$ & $\begin{array}{l}\text { Se o usuário fez uso do } \\
\text { medicamento diariamente }\end{array}$ & Não/Sim \\
\hline $\begin{array}{l}\text { Número de dias em } \\
\text { que fez uso de } \\
\text { medicamento }\end{array}$ & $\begin{array}{l}\text { Número de dias em que o } \\
\text { usuário fez uso do } \\
\text { medicamento }\end{array}$ & Em dias $(4 ; 27 ; 28)$ \\
\hline $\begin{array}{l}\text { Por que não fez uso } \\
\text { do medicamento }\end{array}$ & $\begin{array}{l}\text { Por que o usuário não fez uso } \\
\text { do medicamento }\end{array}$ & Esqueceu, Não achou necessário \\
\hline $\begin{array}{l}\text { Efeitos colaterais do } \\
\text { medicamento }\end{array}$ & $\begin{array}{l}\text { Se o usuário sofreu algum } \\
\text { efeito colateral devido ao uso } \\
\text { do medicamento }\end{array}$ & Não/Sim \\
\hline $\begin{array}{l}\text { Quais efeitos } \\
\text { colaterais do } \\
\text { medicamento }\end{array}$ & $\begin{array}{l}\text { Quais efeitos colaterais o } \\
\text { usuário teve com o uso do } \\
\text { medicamento }\end{array}$ & Questão aberta \\
\hline $\begin{array}{l}\text { Teve vontade de } \\
\text { desistir do } \\
\text { medicamento }\end{array}$ & $\begin{array}{l}\text { Se o usuário teve vontade de } \\
\text { desistir de tomar o } \\
\text { medicamento }\end{array}$ & Não/Sim \\
\hline $\begin{array}{l}\text { Por que teve vontade } \\
\text { de desistir do } \\
\text { medicamento }\end{array}$ & $\begin{array}{l}\text { Por que o usuário teve } \\
\text { vontade de desistir de tomar o } \\
\text { medicamento }\end{array}$ & Questão aberta \\
\hline
\end{tabular}




\begin{tabular}{|c|c|c|}
\hline Variáveis & Descrição & Categorias \\
\hline $\begin{array}{l}\text { Dificuldades para } \\
\text { fazer uso do } \\
\text { medicamento }\end{array}$ & $\begin{array}{l}\text { Se o usuário teve dificuldades } \\
\text { para fazer uso do } \\
\text { medicamento }\end{array}$ & Não/Sim \\
\hline $\begin{array}{l}\text { Preconceito/vergonha, } \\
\text { medo, falta de apoio } \\
\text { de amigos e } \\
\text { familiares }\end{array}$ & $\begin{array}{l}\text { Se o usuário teve } \\
\text { preconceito/vergonha, medo, } \\
\text { falta de apoio de amigos e } \\
\text { familiares }\end{array}$ & Não/Sim \\
\hline Teste rápido para HIV & $\begin{array}{l}\text { Resultado do teste rápido } \\
\text { para HIV }\end{array}$ & $\begin{array}{l}\text { Não reagente, Reagente, Não } \\
\text { realizado }\end{array}$ \\
\hline $\begin{array}{l}\text { Teste rápido para } \\
\text { hepatite } B\end{array}$ & $\begin{array}{l}\text { Resultado do teste rápido } \\
\text { para hepatite } \mathrm{B}\end{array}$ & $\begin{array}{l}\text { Não reagente, Reagente, Não } \\
\text { realizado }\end{array}$ \\
\hline $\begin{array}{l}\text { Teste rápido para } \\
\text { hepatite } \mathrm{C}\end{array}$ & $\begin{array}{l}\text { Resultado do teste rápido } \\
\text { para hepatite } \mathrm{C}\end{array}$ & $\begin{array}{l}\text { Não reagente, Reagente, Não } \\
\text { realizado }\end{array}$ \\
\hline $\begin{array}{l}\text { Teste rápido para } \\
\text { sífilis }\end{array}$ & $\begin{array}{l}\text { Resultado do teste rápido } \\
\text { para sífilis }\end{array}$ & $\begin{array}{l}\text { Não reagente, Reagente, Não } \\
\text { realizado }\end{array}$ \\
\hline $\begin{array}{l}\text { Conversou sobre a } \\
\text { profilaxia }\end{array}$ & $\begin{array}{l}\text { Se o usuário conversou sobre } \\
\text { a profilaxia }\end{array}$ & Não/Sim \\
\hline $\begin{array}{l}\text { Tempo de } \\
\text { permanência no } \\
\text { serviço de saúde }\end{array}$ & $\begin{array}{l}\text { Tempo de permanência do } \\
\text { usuário no serviço de saúde }\end{array}$ & $\leq 1 ; 1 \dashv 2 ;>2$ \\
\hline $\begin{array}{l}\text { Atendimento do } \\
\text { serviço de saúde mais } \\
\text { demorado }\end{array}$ & $\begin{array}{l}\text { Em qual setor do serviço de } \\
\text { saúde o atendimento foi mais } \\
\text { demorado }\end{array}$ & $\begin{array}{l}\text { Balcão, Teste rápido, Acolhimento, } \\
\text { Consulta com o médico, Farmácia }\end{array}$ \\
\hline $\begin{array}{l}\text { O serviço de saúde } \\
\text { atendeu às } \\
\text { necessidades }\end{array}$ & $\begin{array}{l}\text { Se o serviço de saúde atendeu } \\
\text { às necessidades do usuário }\end{array}$ & Não/Sim \\
\hline $\begin{array}{l}\text { Por que o serviço de } \\
\text { saúde atendeu às } \\
\text { necessidades }\end{array}$ & $\begin{array}{l}\text { Por que o serviço de saúde } \\
\text { atendeu às necessidades do } \\
\text { usuário }\end{array}$ & Questão aberta \\
\hline
\end{tabular}

\subsection{ANÁLISE DOS DADOS}

Os resultados obtidos dos questionários foram digitados em um banco de dados no Microsoft Office Excel e transferidos para o STATA (Statistics/Data analysis) versão 15. Foi realizada uma análise descritiva utilizando números absolutos e relativos com frequência simples, média e desvio-padrão, depois uma análise bivariada empregando o teste qui-quadrado e o teste exato de Fisher para a associação da variável dependente com as variáveis independentes, com intervalo de $95 \%$ de confiança e significância de 5\%. 


\subsection{CONSIDERAÇÕES ÉTICAS}

O Projeto foi submetido à Plataforma Brasil e aprovado no Comitê de Ética e Pesquisa (CEP) da EEUSP, conforme Parecer n. 3.167 .045 (Anexo 3) em 25/02/2019, CAAE: 06245519.6.0000.5392, e também pelo CEP da Secretaria Municipal de Saúde de São Paulo e por autorização do CRS Centro, conforme o Parecer n. 3.180 .010 (Anexo 4) em 01/03/2019, CAAE: 06245519.6.3001.0086, atendendo à Resolução n. 466/12.

Antes de iniciar as entrevistas, foi solicitada a anuência formal e a assinatura do TCLE (Apêndice 2) para todos os usuários da pesquisa. 


\section{RESULTADOS}

São apresentados neste capítulo um panorama geral do estudo no baseline, no momento 1 e no momento 2, a caracterização sociodemográfica, as formas de trabalhar e viver, a identificação do processo de saúde, o conhecimento sobre a transmissão e as consequências do HIV, o atendimento do serviço de saúde, os retornos e a adesão à PEP por exposição sexual ao HIV dos 91 usuários indicados para esse procedimento em um SAE HIV/aids.

\subsection{PANORAMA DO ESTUDO NO BASELINE, NO MOMENTO 1 E NO MOMENTO 2}

Iniciam-se os resultados com um panorama geral do estudo no baseline, no momento 1 e no momento 2, com retornos e adesão à PEP. Dos 91 usuários do serviço de saúde incluídos no estudo, foi possível contato com 69 no momento 1 e 46 no momento 2. Em relação ao uso do medicamento, 3 usuários retornaram, mas o pesquisador não estava presente para coletar essa informação e o profissional de saúde não fez a anotação dela no prontuário. Ademais, dos 67 usuários com os quais o contato foi possível, 66 relataram ter feito o uso do medicamento por pelo menos 27 dias, 41 voltaram em pelo menos um retorno e apenas 6 retornaram tanto no momento 1 como no momento 2 e tiveram a informação sobre a tomada do medicamento captada. Dessa forma, conforme os critérios de adesão estabelecidos anteriormente, o índice de adesão no presente estudo foi de 56,7\%, conforme a Figura 7. 
Figura 7. Panorama geral do estudo no baseline, no momento 1 e no momento 2 em relação ao contato, ao retorno, ao uso do medicamento e à adesão.

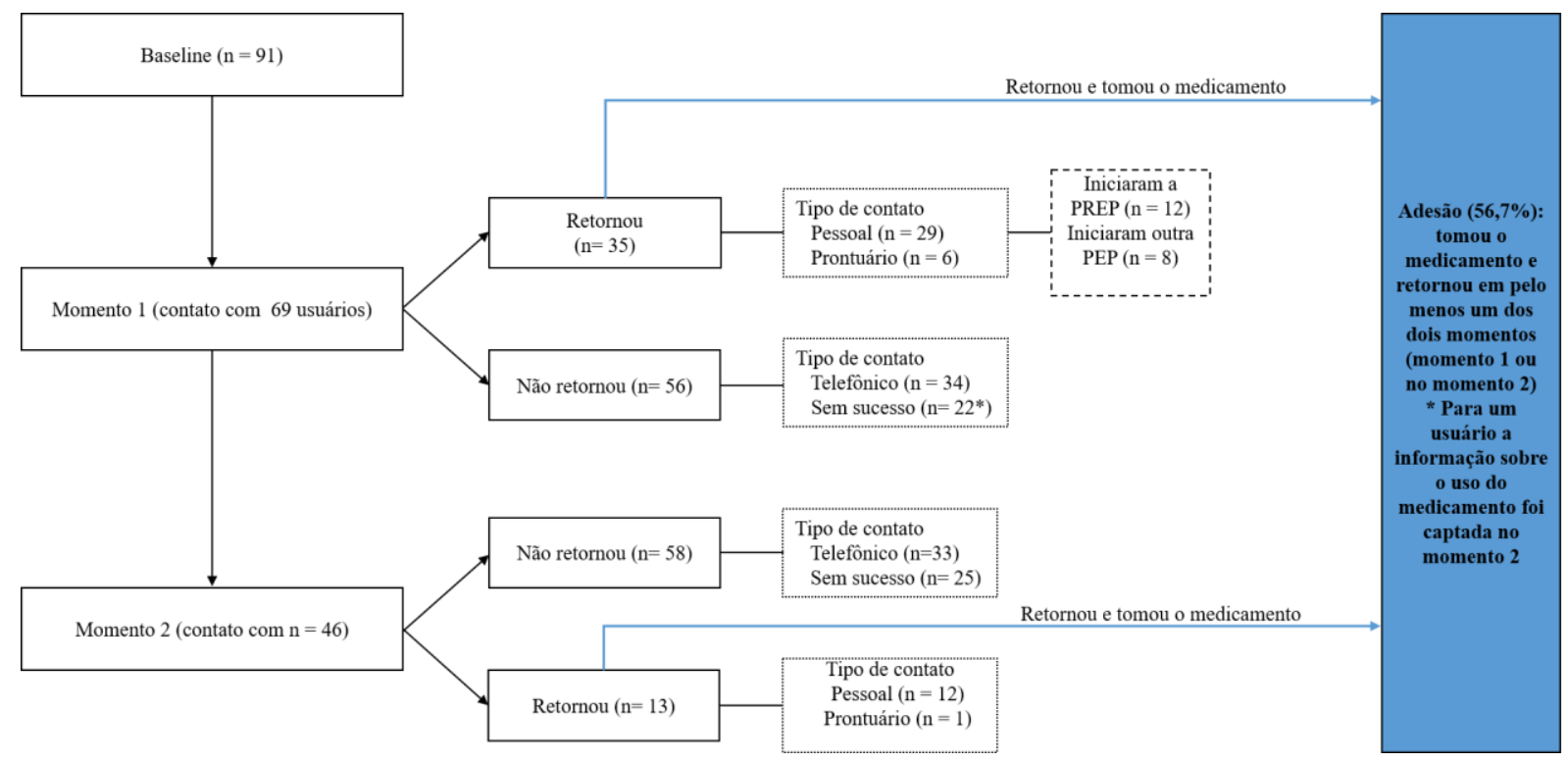

5.2 CARACTERIZAÇÃo SOCIODEMOGRÁFICA, AS FORMAS DE TRABALHAR E VIVER

A maioria dos usuários era do sexo masculino (86,8\%), $\operatorname{HSH}(62,2)$, entre 25 e 44 anos $(64,8 \%)$, da raça branca $(49,5 \%)$ e parda $32(35,2 \%)$, com ensino superior ou pós-graduação $(65,9 \%)$ e morava com outras pessoas $(52,7 \%)$ (Tabela 2$)$.

Tabela 2. Caracterização dos usuários segundo as variáveis sociodemográfica no baseline. São Paulo, 2019.

\begin{tabular}{lcr}
\hline Variável & $\mathbf{n}$ & \% \\
\hline Sexo & & \\
Masculino & 79 & 86,8 \\
Feminino & 12 & 13,2 \\
Idade (anos) & & \\
$15-24$ & 19 & 20,9 \\
$25-44$ & 59 & 64,8 \\
$\geq 45$ & 13 & 14,3 \\
Média (DP) & $32,5(9,8)$ &
\end{tabular}




\begin{tabular}{|c|c|c|}
\hline Variável & $\mathbf{n}$ & $\%$ \\
\hline \multicolumn{3}{|l|}{ Cor autorreferida } \\
\hline Branca & 45 & 49,4 \\
\hline Preta & 12 & 13,2 \\
\hline Parda & 32 & 35,2 \\
\hline Amarela/Indígena & 2 & 2,2 \\
\hline \multicolumn{3}{|l|}{ Escolaridade } \\
\hline Ensino Fundamental/Médio & 31 & 34,1 \\
\hline Ensino Superior/Pós-Graduação & 60 & 65,9 \\
\hline \multicolumn{3}{|l|}{ Local da moradia ${ }^{1}$} \\
\hline São Paulo (município) & 83 & 92,3 \\
\hline Fora de São Paulo (município) & 7 & 7,7 \\
\hline \multicolumn{3}{|l|}{ Com quem mora } \\
\hline Companheiro(a) & 12 & 13,2 \\
\hline Sozinho(a) & 31 & 34,1 \\
\hline Outras pessoas & 48 & 52,7 \\
\hline \multicolumn{3}{|l|}{ Orientação sexual $^{1}$} \\
\hline Heterossexual & 23 & 25,6 \\
\hline Homem que faz sexo com homem & 56 & 62,2 \\
\hline Bissexual & 11 & 12,2 \\
\hline
\end{tabular}

${ }^{1}$ Não foram obtidas informações para a totalidade dos usuários

Durante o período da profilaxia, 12 usuários deixaram o seguimento com a PEP e iniciaram a PrEP por conta de novos episódios de exposição ao HIV, estar em uma relação sorodiscordante ou ser profissional do sexo. Outros 8 usuários, no primeiro retorno ou no intervalo entre o primeiro e o segundo retornos, relataram nova exposição em menos de 72 horas e iniciaram nova PEP, somando, no total, 20 usuários. A tabela a seguir demonstra as características sociodemográficas desses 20 usuários. A maioria era do sexo masculino (90,0\%), HSH (63,2\%), entre 25 e 44 anos (75\%), da raça branca (40,0\%) e morava sozinha $(50,0 \%)$ (Tabela 3$)$. 
Tabela 3. Caracterização dos 20 usuários que iniciaram a PrEP ou uma nova PEP segundo variáveis sociodemográficas no baseline. São Paulo, 2019.

\begin{tabular}{|c|c|c|}
\hline Variável & $\mathbf{n}$ & $\%$ \\
\hline \multicolumn{3}{|l|}{ Sexo } \\
\hline Masculino & 18 & 90,0 \\
\hline Feminino & 2 & 10,0 \\
\hline \multicolumn{3}{|l|}{ Idade (anos) } \\
\hline $15-24$ & 4 & 20,0 \\
\hline $25-44$ & 15 & 75,0 \\
\hline$\geq 45$ & 1 & 5,0 \\
\hline \multicolumn{3}{|l|}{ Raça autorreferida } \\
\hline Branca & 8 & 40,0 \\
\hline Preta & 2 & 10,0 \\
\hline Parda & 10 & 50,0 \\
\hline \multicolumn{3}{|l|}{ Escolaridade } \\
\hline Ensino Fundamental/Médio & 6 & 30,0 \\
\hline Ensino Superior/Pós-Graduação & 14 & 70,0 \\
\hline \multicolumn{3}{|l|}{ Local da moradia $^{1}$} \\
\hline São Paulo (município) & 20 & 100,0 \\
\hline Fora de São Paulo (município) & 0 & 0,0 \\
\hline \multicolumn{3}{|l|}{ Com quem mora } \\
\hline Companheiro(a) & 1 & 5,0 \\
\hline Sozinho(a) & 10 & 50,0 \\
\hline Outras pessoas & 9 & 45,0 \\
\hline \multicolumn{3}{|l|}{ Orientação sexual ${ }^{1}$} \\
\hline Heterossexual & 2 & 10,5 \\
\hline Homem que faz sexo com homem & 12 & 63,2 \\
\hline Bissexual & 5 & 26,3 \\
\hline
\end{tabular}

${ }^{1}$ Não foram obtidas informações para a totalidade dos usuários

Quanto à caracterização dos usuários segundo as formas de trabalhar, a maioria referiu estar trabalhando (84,6\%), sem registro em carteira $(58,4 \%)$, e havia realizado curso preparatório $(70,2 \%)$ para a ocupação que desempenhava no momento da entrevista. A maioria não recebia vale-transporte $(61,5 \%)$, cesta básica $(89,7 \%)$, plano de saúde $(69,2 \%)$ e/ou vale- 
refeição (61,5\%). Em relação à ocupação, a maioria era de planejamento e organização $(28,5 \%)$, empresário, direção e gerência (16,9\%), e 13\% era de profissionais do sexo (Tabela 4).

Tabela 4. Caracterização dos usuários segundo variáveis de formas de trabalhar no baseline. São Paulo, 2019.

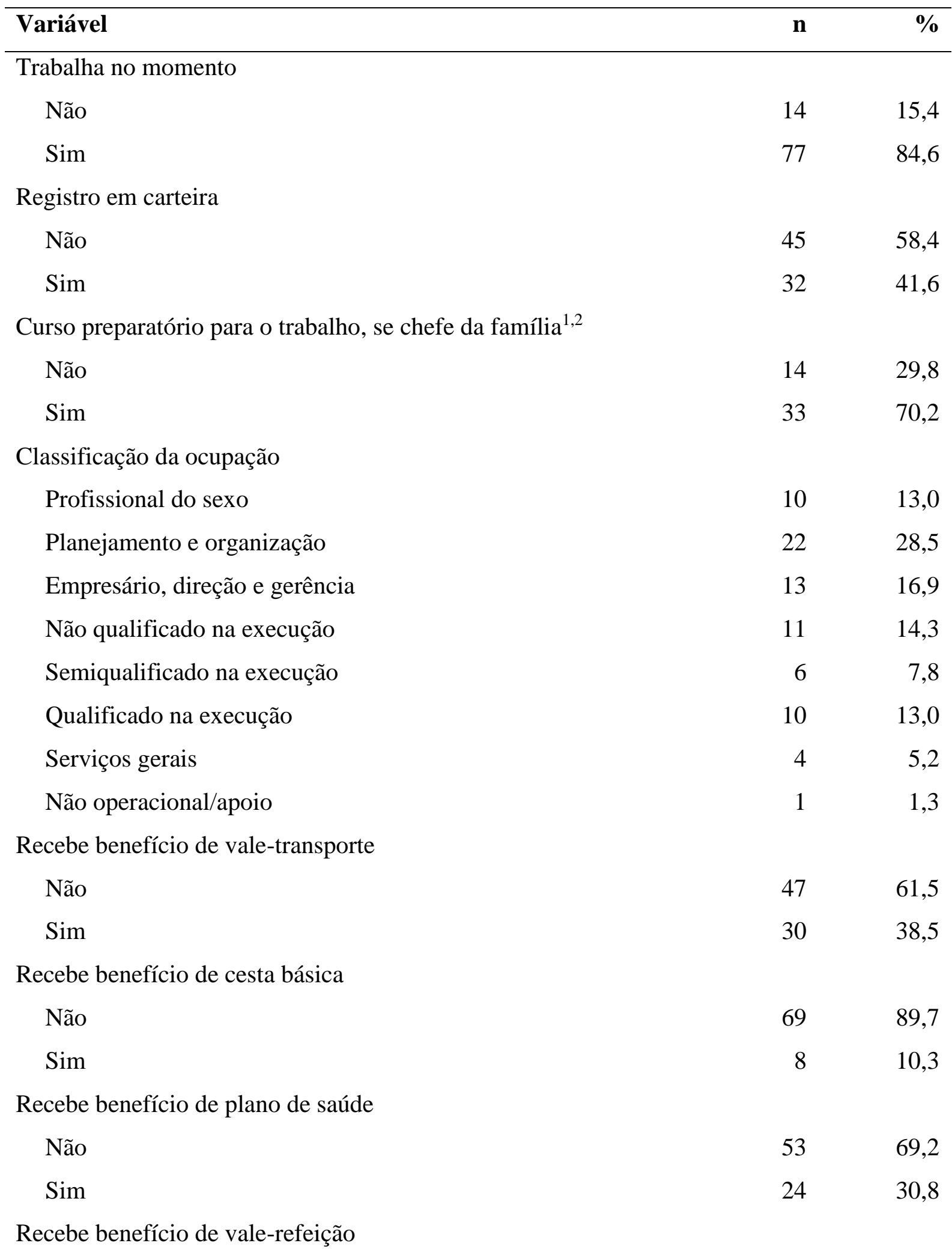




\begin{tabular}{crr}
\hline Variável & $\mathbf{n}$ & $\boldsymbol{\%}$ \\
\hline Não & 48 & 61,5 \\
Sim & 29 & 38,5 \\
\hline
\end{tabular}

${ }^{1}$ Não foram obtidas informações para a totalidade dos usuários

${ }^{2}$ Profissionais do sexo não foram contabilizadas nessa variável

Sobre as formas de viver, identificou-se que a maioria morava em casa alugada $(61,5 \%)$, pagava IPTU $(84,7 \%)$, morava sozinha $(33,0 \%)$, era chefe de família $(68,1 \%)$ e tinha alguma crença religiosa (67\%). A maior parte referiu renda suficiente para alimentação, lazer, escola, vestuário, saúde, transporte e cultura. A minoria recebia algum benefício social $(7,7 \%)$ e participava de algum grupo (13,2\%) (Tabela 5).

Tabela 5. Caracterização dos usuários segundo variáveis de formas de viver no baseline. São Paulo, 2019.

\begin{tabular}{lll}
\hline Variável & n & \%
\end{tabular}

Características do domicílio

Próprio

Alugado

Ocupação/Albergue

Paga Imposto Predial e Territorial Urbano (IPTU) ${ }^{1}$

Não

Sim

Número de pessoas com quem mora

Chefe de família

Próprio usuário

Familiares/Amigos

Crença religiosa

Não

Sim

Suficiência da renda para 


\begin{tabular}{lcc}
\hline Variável & $\mathbf{n}$ & \% \\
\hline Alimentação & 81 & 89,0 \\
Lazer & 68 & 74,7 \\
Escola & 65 & 71,4 \\
Vestuário & 80 & 87,9 \\
Saúde & 70 & 76,9 \\
Transporte & 82 & 90,1 \\
Cultura & 84 & 92,3
\end{tabular}

Recebe benefício social

Não

Sim

Bolsa família

Bolsa de estudos

Seguro-desemprego

Programa de Integração Social (PIS)

Participação em grupos ${ }^{1}$

Não

Sim

Amigos de bairro

Grupo no local de trabalho

Trabalho voluntário

Grupo em igreja

${ }^{1}$ Não foram obtidas informações para a totalidade dos usuários

${ }^{2}$ Acesso à internet, a livros e a revistas

\subsection{PROCESSO DE SAÚDE, CONHECIMENTO SOBRE A TRANSMISSÃO E AS CONSEQUÊNCIAS DO HIV}

Quanto à caracterização dos usuários segundo variáveis do processo de saúde, a maior parte que teve IST anterior relatou tratamento em algum serviço de saúde $(90,9 \%)$. Desses que tiveram IST, a maioria referiu sífilis $(65,6 \%)$. A totalidade teve acesso a preservativo no último ano e 79,1\% relataram uso de preservativo nas relações sexuais. Entretanto, mais da metade não fez uso de preservativo na prática sexual que indicou a $\operatorname{PEP}(57,1 \%)$ e realizava o tratamento da PEP pela primeira vez $(57,1 \%)$, com média de 1,8 e DP $=0,2$ no momento da 
coleta de dados. O tempo de exposição ao HIV até a chegada ao serviço foi de menos de 24 horas para quase a metade dos usuários $(48,3 \%)$ (Tabela 6). 
Tabela 6. Caracterização dos usuários segundo variáveis do processo de saúde no baseline. São Paulo, 2019.

\begin{tabular}{lrr}
\hline Variável & n & \% \\
\hline Tratamento de IST anterior & 30 & 90,9 \\
$\quad$ Serviço de saúde & 2 & 6,1 \\
Automedicação & 1 & 3,0 \\
Não tratou & & \\
Qual foi a IST anterior ${ }^{1}$ & 21 & 65,6 \\
Sífilis & 6 & 18,8 \\
Gonorreia & 4 & 12,5 \\
Papilomavírus humano (HPV) & 1 & 3,1 \\
Hepatite B & &
\end{tabular}

Uso de drogas no momento

Não

$58 \quad 63,7$

$\operatorname{Sim}$

$33 \quad 36,3$

Realizou exame anterior para HIV

Não

$8 \quad 8,8$

Sim

8391,2

Tempo da última exposição ao HIV (horas)

$\leq 24$

$44 \quad 48,3$

$25 \dashv 48$

$30 \quad 33,0$

$49-72$

$17 \quad 18,7$

Uso de preservativo nas relações sexuais

Não

$19 \quad 20,9$

Sim

$72 \quad 79,1$

Teve acesso a preservativo no último ano

Não

Sim

$91 \quad 100,0$

Serviço de saúde que disponibilizou preservativo

Público

$12 \quad 13,2$

Comprou na farmácia

$36 \quad 39,6$

Público ou comprou na farmácia

$43 \quad 47,2$

Como obteve informação sobre a $\mathrm{PEP}^{1}$

Equipe de saúde

$18 \quad 22,8$ 


\begin{tabular}{lrr}
\hline Variável & $\mathbf{n}$ & $\boldsymbol{\%}$ \\
\hline Propaganda sobre a PEP & 15 & 19,0 \\
Buscou informação sobre a PEP & 20 & 25,3 \\
Amigos & 26 & 32,9
\end{tabular}

Número de vezes em que fez uso da PEP
$1^{\mathrm{a}}$
$52 \quad 57,1$
$2^{\mathrm{a}}$
$23 \quad 25,3$
$\geq 3^{\mathrm{a}}$
$16 \quad 17,6$
Média (DP) para quem fez uso de mais de uma PEP

Tipo de prática sexual que indicou a $\mathrm{PEP}^{1}$

Anal ou vaginal

$70 \quad 93,3$

Oral

$5 \quad 6,7$

Uso do preservativo na prática sexual que indicou a $\mathrm{PEP}^{1}$

Não

$44 \quad 57,1$

Sim

$33 \quad 42,9$

${ }^{1}$ Não foram obtidas informações para a totalidade dos usuários

Praticamente a totalidade $(94,5 \%)$ disse conhecer as formas de transmissão e as consequências do HIV no corpo humano $(79,1 \%)$. A maioria relatou a relação sexual como principal transmissão do $\operatorname{HIV}(82,4 \%)$ e a queda da imunidade como decorrência da doença $(63,7 \%)$. Além disso, relacionaram a transmissão do HIV a condições variadas (Tabela 7). 
Tabela 7. Conhecimento sobre a transmissão e as consequências do HIV. São Paulo, 2019.

\begin{tabular}{lrr}
\hline Variável & $\mathbf{n}$ & \% \\
\hline Conhecimento sobre a transmissão do HIV & 5 & 5,5 \\
Nenhum & 86 & 94,5 \\
Algum & 20 & 22,0 \\
$\quad$ Uso de seringa & 7 & 7,7 \\
$\quad$ Transmissão vertical & 9 & 9,9 \\
Transfusão sanguínea & 75 & 82,4 \\
$\quad$ Relação sexual & 35 & 38,5 \\
Contato com sangue & 20 & 22,0 \\
Fluidos e secreção & & \\
Conhecimento sobre o que o HIV pode causar no corpo humano & 19 & 20,9 \\
Nenhum & 72 & 79,1 \\
Algum & 58 & 63,7 \\
Queda da imunidade & 6 & 6,6 \\
Dúvida do que pode causar & 1 & 1,1 \\
Morte & & \\
\hline
\end{tabular}

\subsection{ATENDIMENTO NO SAE}

Quanto ao atendimento realizado no serviço de saúde (Tabela 8), a maioria dos entrevistados iniciou a PEP nesse serviço, onde fazem o acompanhamento (95,6\%), e 4,4\% a iniciaram em outro serviço.

Tabela 8. Caracterização dos usuários segundo variáveis do serviço de saúde no baseline. São Paulo, 2019.

\begin{tabular}{lrr}
\hline Variável & n & \% \\
\hline Em qual serviço de saúde iniciou a PEP & & \\
Nesse serviço de saúde (serviço onde a pesquisa foi realizada) & 87 & 95,6 \\
Em outro serviço de saúde & 4 & 4,4 \\
Tipo de serviço de saúde em que iniciou a PEP & & \\
SAE & 87 & 95,6 \\
AMA & 1 & 1,1
\end{tabular}


Emílio Ribas

\subsection{RETORNOS DOS USUÁRIOS INDICADOS À PEP - 30 DIAS E 90 DIAS}

No primeiro retorno - 30 dias - após a indicação da PEP, verificou-se que $56(61,5 \%)$ não voltaram e $35(38,5 \%)$ voltaram, do total no baseline de 91 . Para os usuários que não retornaram, foi realizado contato telefônico com sucesso com 34 usuários $(60,7 \%)$, e com o restante não se obteve sucesso na ligação. Para os usuários que retornaram, o tipo de contato estabelecido foi pessoal $(\mathrm{n}=29,82,9 \%)$ ou buscou-se informações por meio do prontuário ( $\mathrm{n}$ $=6,17,1 \%)$.

Em relação aos motivos do não retorno no momento 1, entre os usuários cujo contato telefônico teve sucesso $(\mathrm{N}=34)$, o principal motivo foi o trabalho $(55,9 \%)$, seguido do esquecimento e de não achar que o retorno seria necessário - ambos com 11,8\%. Ademais, os outros motivos foram: usuário mencionou vontade de realizar o retorno em outro serviço público de saúde $(5,9 \%)$ ou em um serviço particular $(5,9 \%)$, por estar viajando no dia do retorno $(5,9)$ e por ter realizado o autoteste em casa $(2,8 \%)$. No momento 2 , os motivos do não retorno entre os usuários cujo contato telefônico teve sucesso $(\mathrm{N}=33)$ foram: o trabalho $(48,5 \%)$, esquecer o dia do retorno $(18,2 \%)$, intenção manifesta de que iria a um serviço particular (15,2\%), a distância da residência até o serviço de saúde (6,0\%), estar viajando no dia do retorno $(3,0 \%)$, a pessoa com quem se relacionou realizou o teste e teve teste rápido negativo para o HIV (3,0\%) ou não saber que era necessário retornar ao serviço de saúde $(3,0 \%)$ (dados não apresentado em tabela).

Na Tabela 9, encontram-se representados os que não retornaram, mas com os quais foi possível contato telefônico, e os que retornaram, com um total de 69 usuários. Entre os usuários que não retornaram, a maioria tomou o medicamento todos os dias $(91,4 \%), 42,3 \%$ referiram efeito adverso, 14,3\% expressaram vontade de desistir de tomar o medicamento e 10,7\% tiveram dificuldade para tomar o medicamento. Entre os usuários que retornaram, a maioria tomou o medicamento todos os dias $(93,8 \%), 50,0 \%$ sofreram efeito colateral, 3,3\% tiveram vontade desistir de tomar o medicamento e 22,9\% tiveram dificuldade para tomar o medicamento. A informação sobre o uso do medicamento foi captada, também, no momento 2 para o usuário cujo contato telefônico não teve sucesso no momento 1. 
Tabela 9. Caracterização dos usuários segundo variáveis do processo saúde e doença no momento 1. São Paulo, 2019.

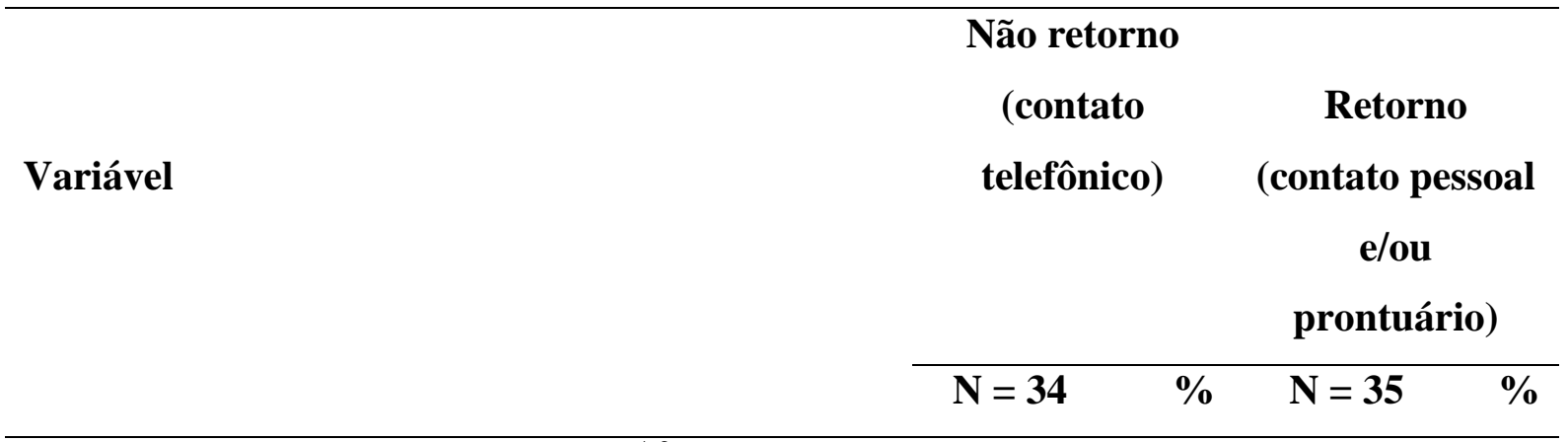

Fez uso do medicamento diariamente ${ }^{1,2}$

Não

Sim

Número de dias em que fez uso do medicamento ${ }^{2}$

28

27

4

Por que não fez uso do medicamento ${ }^{2}$

Esqueceu

Não achou necessário

Efeitos colaterais do medicamento ${ }^{1,2,3}$

Não

Sim

Náuseas

Vômito

Diarreia

Dor abdominal

Olhos amarelados

Sonolência

Outros

Teve vontade de desistir do medicamento ${ }^{2}$

Não

Sim

Parceiro não tinha HIV

Não valeria a pena

Devido aos efeitos colaterais

$\begin{array}{rrrr}3 & 8,6 & 2 & 6,2 \\ 32 & 91,4 & 30 & 93,8\end{array}$

$32 \quad 91,4$

$30 \quad 93,7$

$2 \quad 5,7$

26,3

12,9

$0 \quad 0,0$

266,7

2100,0

133,3

$0 \quad 0,0$

$\begin{array}{rrrr}20 & 57,1 & 16 & 50,0 \\ 15 & 42,9 & 16 & 50,0 \\ 7 & 46,7 & 8 & 50,0 \\ 0 & 0,0 & 2 & 12,5 \\ 4 & 26,7 & 6 & 37,5 \\ 1 & 6,7 & 2 & 12,5 \\ 1 & 6,7 & 0 & 0,0 \\ 1 & 6,7 & 6 & 37,5 \\ 8 & 53,3 & 8 & 50,0\end{array}$

30

85,7

$29 \quad 96,7$

$\begin{array}{llll}5 & 14,3 & 1 & 3,3\end{array}$

$120,0 \quad 0 \quad 0,0$

$120,0 \quad 0 \quad 0,0$

$240,0 \quad 1 \quad 100,0$ 
Não retorno

(contato

Variável

telefônico)

Retorno

(contato pessoal

e/ou

prontuário)

\begin{tabular}{lrrrr}
\cline { 2 - 5 } & $\mathbf{N}=\mathbf{3 4}$ & $\boldsymbol{\%}$ & $\mathbf{N}=\mathbf{3 5}$ & $\boldsymbol{\%}$ \\
\hline Porque queria ingerir álcool & 1 & 20,0 & 0 & 0,0
\end{tabular}

Dificuldades para fazer uso do medicamento ${ }^{2,4}$

\begin{tabular}{lrrrr} 
Não & 29 & 82,8 & 27 & 77,1 \\
Sim & 6 & 17,2 & 8 & 22,9 \\
Preconceito ou vergonha & 3 & 50,0 & 5 & 62,5 \\
Medo & 1 & 16,7 & 2 & 25,0 \\
Falta de apoio de amigos e familiares & 2 & 33,3 & 3 & 37,5 \\
\hline
\end{tabular}

${ }^{1}$ Não foram obtidas informações para a totalidade dos usuários

${ }^{2}$ Variáveis com informações captadas, também, no momento 2

${ }^{3}$ Um usuário pode ter sofrido mais do que um efeito colateral

${ }^{4}$ Um usuário pode ter sofrido mais do que uma dificuldade para fazer o uso do medicamento

No segundo momento - 90 dias - após a indicação da PEP, do total de 91 usuários do SAE HIV/aids, 12 foram indicados para PrEP e 8 iniciaram uma nova PEP. Nesse sentido, restaram 71 usuários que poderiam voltar no momento 2. No segundo momento (momento 2), $58(81,7 \%)$ não retornaram e $13(18,3 \%)$ retornaram. No caso dos usuários que não retornaram, foi realizado contato telefônico com apenas 33 deles $(56,9 \%)$, pois com $25(43,1 \%)$ o contato não teve sucesso. Para os usuários que retornaram, o tipo de contato estabelecido foi pessoal (n $=12,92,3 \%)$ ou por prontuário $(\mathrm{n}=1,7,7 \%)$.

A Tabela 10 apresenta um consolidado das variáveis que se repetem nos três momentos - baseline, momento 1 e momento 2 - e que tratam da caracterização dos usuários sobre as variáveis do processo de saúde segundo os retornos. Dos 91 usuários, $1(1,1 \%)$ teve teste rápido reagente para hepatite $\mathrm{B}$, mas esse usuário relatou ter tido o diagnóstico anteriormente, e 27 $(29,7 \%)$ para sífilis - desses, $21(77,8 \%)$ já tinham sífilis. Entre os usuários que retornaram para realizar a teste rápido para HIV, nenhum soroconverteu após o uso da PEP. Em relação a conversar com alguém sobre a profilaxia, no baseline, a maioria dos usuários relatou ter conversado com alguém: no momento 1 , tanto entre os usuários que retornam como entre os que não retornam, a maioria não conversou com ninguém; e, no momento 2 , entre os usuários que não retornaram, a maioria não conversou sobre a PEP com outras pessoas. 
A Tabela 11 apresenta uma caracterização dos usuários sobre o atendimento no serviço de saúde no baseline, no momento 1 e no momento 2 , segundo os retornos. $\mathrm{O}$ tempo em que o usuário permaneceu no serviço de saúde foi diminuindo conforme os retornos. O que mais demorou foi o teste rápido e, para a maioria dos usuários, o serviço de saúde atendeu a suas necessidades $(98,9 \%)$, devido ao bom atendimento dos profissionais de saúde, à realização de testes rápidos e ao atendimento do serviço ter ocorrido da maneira que o usuário esperava. 
Tabela 10. Caracterização dos usuários sobre variáveis do processo de saúde no baseline, no momento 1 e no momento 2 , segundo os retornos. São Paulo, 2019.

\begin{tabular}{|c|c|c|c|c|c|c|c|c|c|c|}
\hline \multirow[t]{4}{*}{ Variável } & \multicolumn{2}{|c|}{ Baseline } & \multicolumn{4}{|c|}{ Momento 1} & \multicolumn{4}{|c|}{ Momento 2} \\
\hline & & & \multicolumn{2}{|c|}{$\begin{array}{l}\text { Não retorno } \\
\text { (contato } \\
\text { telefônico) }\end{array}$} & \multicolumn{2}{|c|}{$\begin{array}{c}\text { Retorno (contato) } \\
\text { pessoal e/ou } \\
\text { prontuário) }\end{array}$} & \multicolumn{2}{|c|}{$\begin{array}{l}\text { Não retorno } \\
\text { (contato } \\
\text { telefônico) }\end{array}$} & \multicolumn{2}{|c|}{$\begin{array}{c}\text { Retorno (contato) } \\
\text { pessoal e/ou } \\
\text { prontuário) }\end{array}$} \\
\hline & & & \multicolumn{2}{|c|}{$n=34$} & \multicolumn{2}{|c|}{$\mathbf{n}=\mathbf{3 5}$} & \multicolumn{2}{|c|}{$\mathbf{n}=\mathbf{3 3}$} & \multicolumn{2}{|c|}{$n=13$} \\
\hline & $\mathbf{n}$ & $\%$ & $\mathbf{n}$ & $\%$ & $\mathbf{n}$ & $\%$ & $\mathbf{n}$ & $\%$ & $\mathbf{n}$ & $\%$ \\
\hline Não reagente & 91 & 100,0 & - & - & 35 & 100,0 & - & & 13 & 100,0 \\
\hline Reagente & 0 & 0,0 & - & - & 0 & 0,0 & - & & 0 & 0,0 \\
\hline \multicolumn{11}{|c|}{ Teste rápido para hepatite $\mathrm{B}$} \\
\hline Não reagente & 90 & 98,9 & - & - & 33 & 94,3 & - & & 13 & 100,0 \\
\hline \multicolumn{11}{|c|}{ Teste rápido para hepatite $\mathrm{C}$} \\
\hline Não reagente & 91 & 100,0 & & & 33 & 94,3 & - & & 13 & 100,0 \\
\hline Reagente & 0 & 0,0 & - & - & 0 & 0,0 & - & & 0 & 0,0 \\
\hline Não realizado & 0 & 0,0 & - & - & 2 & 5,7 & - & & 0 & 0,0 \\
\hline \multicolumn{11}{|c|}{ Teste rápido para sífilis } \\
\hline Não reagente & 64 & 70,3 & - & - & 23 & 65,7 & - & & 12 & 92,3 \\
\hline Reagente & 27 & 29,7 & - & - & 10 & 28,6 & - & & 1 & 7,7 \\
\hline
\end{tabular}




\begin{tabular}{|c|c|c|c|c|c|c|c|c|c|c|}
\hline \multirow[t]{4}{*}{ Variável } & \multicolumn{2}{|c|}{ Baseline } & \multicolumn{4}{|c|}{ Momento 1} & \multicolumn{4}{|c|}{ Momento 2} \\
\hline & & & \multicolumn{2}{|c|}{$\begin{array}{l}\text { Não retorno } \\
\text { (contato } \\
\text { telefônico) }\end{array}$} & \multicolumn{2}{|c|}{$\begin{array}{c}\text { Retorno (contato) } \\
\text { pessoal e/ou } \\
\text { prontuário) }\end{array}$} & \multicolumn{2}{|c|}{$\begin{array}{l}\text { Não retorno } \\
\text { (contato } \\
\text { telefônico) }\end{array}$} & \multicolumn{2}{|c|}{$\begin{array}{c}\text { Retorno (contato) } \\
\text { pessoal e/ou } \\
\text { prontuário) }\end{array}$} \\
\hline & & & \multicolumn{2}{|c|}{$\mathrm{n}=\mathbf{3 4}$} & \multicolumn{2}{|c|}{$\mathrm{n}=\mathbf{3 5}$} & \multicolumn{2}{|c|}{$\mathbf{n}=\mathbf{3 3}$} & \multicolumn{2}{|c|}{$n=13$} \\
\hline & $\mathbf{n}$ & $\%$ & $\mathbf{n}$ & $\%$ & $\mathbf{n}$ & $\%$ & $\mathbf{n}$ & $\%$ & $\mathbf{n}$ & $\%$ \\
\hline Não realizado & 0 & 0,0 & - & - & 2 & 5,7 & - & - & 0 & 0,0 \\
\hline \multicolumn{11}{|c|}{ Conversou sobre a profilaxia ${ }^{1}$} \\
\hline Não & 41 & 45,0 & 17 & 51,5 & 16 & 52,4 & 21 & 67,8 & 6 & 50,0 \\
\hline Sim & 50 & 55,0 & 16 & 48,5 & 14 & 47,6 & 10 & 32,2 & 6 & 50,0 \\
\hline
\end{tabular}


Tabela 11. Caracterização dos usuários sobre variáveis do serviço de saúde no baseline, no momento 1 e no momento 2 , segundo os retornos. São Paulo, 2019.

\begin{tabular}{|c|c|c|c|c|c|}
\hline \multirow[t]{3}{*}{ Variável } & \multirow[t]{2}{*}{ Baseline } & \multicolumn{2}{|c|}{ Momento 1} & \multicolumn{2}{|c|}{ Momento 2} \\
\hline & & $\begin{array}{c}\text { Não retorno } \\
\text { (contato } \\
\text { telefônico) }\end{array}$ & $\begin{array}{c}\text { Retorno } \\
\text { (contato pessoal } \\
\text { e/ou prontuário) }\end{array}$ & $\begin{array}{c}\text { Não retorno } \\
\text { (contato } \\
\text { telefônico) }\end{array}$ & $\begin{array}{c}\text { Retorno } \\
\text { (contato } \\
\text { pessoal e/ou } \\
\text { prontuário) }\end{array}$ \\
\hline & & $n=34$ & $n=35$ & $n=33$ & $n=13$ \\
\hline & $\mathbf{n}$ & $\%$ & $\%$ & $\%$ & $\mathbf{n}$ \\
\hline
\end{tabular}

Tempo de permanência no serviço de saúde (em horas $)^{1}$

$\leq 1$
$1 \dashv 2$
$>2$

$\begin{array}{rrrrrrrrrr}8 & 8,7 & - & - & 5 & 16,7 & - & - & 6 & 50,0 \\ 28 & 30,8 & - & - & 20 & 66,7 & - & - & 3 & 25,0 \\ 55 & 60,5 & - & - & 4 & 16,6 & - & - & 3 & 25,0\end{array}$

Atendimento do serviço de saúde mais demorado $^{1}$

Balcão

Teste rápido

Acolhimento

Consulta com o médico

Farmácia

$\begin{array}{rrrrrrrrrr}33 & 36,3 & - & - & 8 & 26,7 & - & - & 1 & 8,3 \\ 42 & 46,1 & - & - & 19 & 63,3 & - & - & 8 & 66,7 \\ 7 & 7,7 & - & - & 3 & 10,0 & - & - & 3 & 25,0 \\ 8 & 8,8 & - & - & - & - & - & - & - & - \\ 1 & 1,1 & - & - & - & - & - & - & - & -\end{array}$

O serviço de saúde atendeu às necessidades ${ }^{1}$ 


\begin{tabular}{|c|c|c|c|c|c|c|c|c|c|c|}
\hline \multirow[t]{4}{*}{ Variável } & \multicolumn{2}{|c|}{ Baseline } & \multicolumn{4}{|c|}{ Momento 1} & \multicolumn{4}{|c|}{ Momento 2} \\
\hline & & & \multicolumn{2}{|c|}{$\begin{array}{c}\text { Não retorno } \\
\text { (contato } \\
\text { telefônico) }\end{array}$} & \multicolumn{2}{|c|}{$\begin{array}{c}\text { Retorno } \\
\text { (contato pessoal } \\
\text { e/ou prontuário) }\end{array}$} & \multicolumn{2}{|c|}{$\begin{array}{l}\text { Não retorno } \\
\text { (contato } \\
\text { telefônico) }\end{array}$} & \multicolumn{2}{|c|}{$\begin{array}{c}\text { Retorno } \\
\text { (contato } \\
\text { pessoal e/ou } \\
\text { prontuário) }\end{array}$} \\
\hline & & & \multicolumn{2}{|c|}{$\mathrm{n}=\mathbf{3 4}$} & \multicolumn{2}{|c|}{$\mathbf{n}=\mathbf{3 5}$} & \multicolumn{2}{|c|}{$\mathbf{n}=\mathbf{3 3}$} & \multicolumn{2}{|c|}{$\mathbf{n}=\mathbf{1 3}$} \\
\hline & $\mathbf{n}$ & $\%$ & $\mathbf{n}$ & $\%$ & $\mathbf{n}$ & $\%$ & $\mathbf{n}$ & $\%$ & $\mathbf{n}$ & $\%$ \\
\hline Não & 1 & 1,1 & - & - & 4 & 13,3 & - & - & 0 & 0,0 \\
\hline Sim & 90 & 98,9 & - & - & 26 & 86,7 & - & - & 12 & 100,0 \\
\hline Era o que esperava & 34 & 62,2 & - & - & 6 & 23,1 & - & - & 1 & 8,3 \\
\hline Bom atendimento dos profissionais & 39 & 43,3 & - & - & 10 & 38,5 & - & - & 4 & 33,3 \\
\hline Forneceu remédios & 27 & 70,0 & - & - & - & - & - & - & - & - \\
\hline Consulta médica & 2 & 2,2 & - & - & - & - & - & - & - & - \\
\hline Fez teste rápido & 17 & 18,9 & - & - & 8 & 30,8 & - & - & 1 & 8,3 \\
\hline Rápido atendimento & 11 & 12,2 & - & - & 6 & 23,1 & - & - & 7 & 58,3 \\
\hline Responderam às dúvidas & 19 & 21,1 & - & - & 1 & 3,9 & - & - & 1 & 8,3 \\
\hline Recebeu aconselhamento & 0 & 0,0 & - & - & 3 & 10,3 & - & - & 0 & 0,0 \\
\hline
\end{tabular}

${ }^{1}$ Não foram obtidas informações para a totalidade dos usuários 


\subsection{ADESÃO À PEP POR EXPOSIÇÃO SEXUAL AO HIV EM UM SAE HIV/AIDS}

A Tabela 12 apresenta a comparação das variáveis sociodemográficas associadas com a adesão à PEP. Observou-se pequena diferença em termo percentual na distribuição dos participantes do estudo em relação à adesão $(92,1 \%)$ ou à não adesão $(89,7 \%)$ segundo o sexo, com concentração no masculino. Houve concentração na faixa dos 25 a 44 anos, com aproximação percentual entre os que aderiram $(65,8 \%)$ e não aderiram $(68,9 \%)$. Tem-se diferença em termo percentual para as variáveis raça autorreferida, escolaridade e orientação sexual, sendo a não adesão mais prevalente entre os usuários da cor preta, com ensino superior e pós-graduação e HSH, respectivamente, e do sexo feminino, mas estes não se mostraram estatisticamente significante.

Tabela 12. Comparação das variáveis sociodemográficas associadas com a adesão à PEP. São Paulo, 2019.

\begin{tabular}{|c|c|c|c|c|c|}
\hline \multirow{3}{*}{ Variáveis } & \multicolumn{5}{|c|}{ Adesão } \\
\hline & \multicolumn{2}{|c|}{ Não } & \multicolumn{2}{|c|}{ Sim } & \multirow[t]{2}{*}{$p$} \\
\hline & $\mathbf{N}=\mathbf{2 9}$ & $\%$ & $\mathbf{N}=\mathbf{3 8}$ & $\%$ & \\
\hline \multicolumn{6}{|l|}{$\operatorname{Sexo}^{2}$} \\
\hline Masculino & 26 & 89,7 & 35 & 92,1 & 1,000 \\
\hline Feminino & 3 & 10,3 & 3 & 7,9 & \\
\hline \multicolumn{6}{|l|}{ Idade $^{2}$} \\
\hline $15-24$ & 5 & 17,2 & 7 & 18,4 & 1,000 \\
\hline $25-44$ & 20 & 69,0 & 25 & 65,8 & \\
\hline$\geq 45$ & 4 & 13,8 & 6 & 15,8 & \\
\hline \multicolumn{6}{|l|}{ Cor autorreferida $^{1}$} \\
\hline Branca & 16 & 55,2 & 19 & 50,0 & 0,632 \\
\hline Preta & 4 & 13,8 & 3 & 7,9 & \\
\hline Parda & 9 & 31,0 & 15 & 39,5 & \\
\hline Indígena & 0 & 0,0 & 1 & 2,6 & \\
\hline \multicolumn{6}{|l|}{ Escolaridade $^{1}$} \\
\hline Ensino Fundamental/Médio & 5 & 17,2 & 11 & 28,9 & 0,265 \\
\hline Ensino Superior/Pós-Graduação & 24 & 82,8 & 27 & 71,1 & \\
\hline Local da moradia ${ }^{2}$ & & & & & 1,000 \\
\hline
\end{tabular}


Adesão

\begin{tabular}{|c|c|c|c|c|c|}
\hline \multirow[t]{2}{*}{ Variáveis } & \multicolumn{2}{|c|}{ Não } & \multicolumn{2}{|c|}{ Sim } & \multirow[t]{2}{*}{$p$} \\
\hline & $\mathrm{N}=\mathbf{2 9}$ & $\%$ & $\mathbf{N}=\mathbf{3 8}$ & $\%$ & \\
\hline São Paulo (município) & 26 & 89,7 & 35 & 92,1 & \\
\hline Fora de São Paulo (município) & 3 & 10,3 & 3 & 7,9 & \\
\hline Com quem mora $^{2}$ & & & & & 0,936 \\
\hline Companheiro(a) & 2 & 6,9 & 4 & 10,5 & \\
\hline Sozinho(a) & 11 & 37,9 & 13 & 34,2 & \\
\hline Outras pessoas & 16 & 55,2 & 21 & 55,3 & \\
\hline \multicolumn{6}{|l|}{ Orientação sexual ${ }^{1,3}$} \\
\hline Homens que fazem sexo com homem & 20 & 69,0 & 23 & 62,2 & 0,437 \\
\hline Heterossexual & 4 & 13,8 & 10 & 27,0 & \\
\hline Bissexual & 5 & 17,2 & 4 & 10,8 & \\
\hline
\end{tabular}

${ }^{1}$ Teste qui-quadrado

${ }^{2}$ Teste Exato de Fisher

${ }^{3}$ Não foram obtidas informações para a totalidade dos usuários

A comparação das variáveis de formas de trabalhar associadas com a adesão à PEP (Tabela 13) mostrou que a não adesão é mais prevalente entre os usuários que não estavam trabalhando, com registro em carteira, com curso preparatório para o trabalho (quando o usuário era o chefe da família), que ocupavam cargos que necessitavam de qualificação na execução e aqueles que recebiam benefícios referentes ao trabalho - plano de saúde, valerefeição e vale-transporte. Em relação ao plano de saúde, houve diferença em termo percentual na distribuição dos participantes do estudo quanto à adesão $(54,3 \%)$ ou não adesão $(72,77 \%)$; os que tinham o plano aderiram menos, com teste estatisticamente significante ( $\mathrm{p}$ $=0,039)$.

Tabela 13. Comparação das variáveis de formas de trabalhar associadas com a adesão à PEP. São Paulo, 2019.

\section{Variáveis}

Adesão

\begin{tabular}{lllll}
\hline Não & \multicolumn{2}{c}{ Sim } & & $p$ \\
\hline $\mathrm{N}=\mathbf{2 9}$ & $\%$ & $\mathrm{~N}=\mathbf{3 8}$ & $\%$ &
\end{tabular}

Trabalha no momento ${ }^{2}$

Não

$\operatorname{Sim}$
$5 \quad 17,2$

$24 \quad 82,8$
$5 \quad 13,2 \quad 0,642$

3386,8

Registro em carteira ${ }^{1}$ 
Adesão

\begin{tabular}{lrrrrrrr} 
& \multicolumn{1}{c}{ Não } & \multicolumn{2}{c}{ Sim } & & $\boldsymbol{p}$ \\
\cline { 2 - 7 } & $\mathbf{N = \mathbf { 2 9 }}$ & $\mathbf{\%}$ & $\mathbf{N}=\mathbf{3 8}$ & $\boldsymbol{\%}$ & \\
\hline Não & 11 & 45,8 & 17 & 51,5 & 0,672 \\
Sim & 13 & 54,2 & & 16 & 48,5 &
\end{tabular}

Curso preparatório para o trabalho, se chefe da

família ${ }^{2,3}$

Não

$\begin{array}{lllll}3 & 20,0 & 7 & 35,0 & 0,458\end{array}$

Sim

$1280,0 \quad 13 \quad 65,0$

Classificação da ocupação ${ }^{1}$

Profissional do sexo

$0 \quad 0,0$

$4 \quad 12,1 \quad 0,127$

Planejamento e organização

$7 \quad 29,3$

1236,4

Empresário, direção e gerência

$5 \quad 20,8$

$4 \quad 12,1$

Não qualificado na execução

$5 \quad 20,8$

$3 \quad 9,1$

Semiqualificado na execução

28,3

39,1

Qualificado na execução

$5 \quad 20,8$

26,1

Serviços gerais

$0 \quad 0,0$

412,1

Não operacional/apoio

$0 \quad 0,0$

13,0

Recebe benefício de vale-transporte ${ }^{1}$

$\begin{array}{llllll}\text { Não } & 10 & 41,7 & 20 & 60,6 & 0,157 \\ \text { Sim } & 14 & 58,3 & 13 & 39,4 & \end{array}$

Recebe benefício de cesta básica ${ }^{2}$

$\begin{array}{lrrrrr}\text { Não } & 19 & 79,2 & 30 & 90,9 & 0,261 \\ \text { Sim } & 5 & 20,8 & 3 & 9,1 & \end{array}$

Recebe benefício de plano de saúde ${ }^{1}$

$\begin{array}{rrrrrr}\text { Não } & 11 & 45,8 & 24 & 72,7 & \mathbf{0 , 0 3 9} \\ \text { Sim } & 13 & 54,2 & 9 & 27,3 & \end{array}$

Recebe benefício de vale-refeição ${ }^{1}$

$\begin{array}{llllll}\text { Não } & 10 & 41,7 & 20 & 60,6 & 0,157 \\ \text { Sim } & 14 & 58,3 & 13 & 39,4 & \end{array}$

\footnotetext{
${ }^{1}$ Teste qui-quadrado

2 Teste Exato de Fisher

${ }^{3}$ Profissionais do sexo não foram contabilizados(as) nesta variável
}

A comparação das variáveis de formas de viver associadas com a adesão à PEP (Tabela 14) mostrou que a não adesão foi mais prevalente entre os usuários que não tinham 
renda suficiente para saúde, não tinham crença religiosa e participavam de algum grupo associativo. Esses resultados não foram estatisticamente significantes.

Tabela 14. Comparação das variáveis de formas de viver associadas com a adesão à PEP. São Paulo, 2019.

\begin{tabular}{|c|c|c|c|c|c|}
\hline \multirow[t]{3}{*}{ Variáveis } & \multicolumn{5}{|c|}{ Adesão } \\
\hline & \multicolumn{2}{|l|}{ Não } & \multicolumn{2}{|l|}{ Sim } & \multirow[t]{2}{*}{$p$} \\
\hline & $\mathbf{N}=\mathbf{2 9}$ & $\%$ & $\mathbf{N}=\mathbf{3 8}$ & $\%$ & \\
\hline \multicolumn{6}{|c|}{ Características do domicílio $^{2}$} \\
\hline Próprio & 11 & 37,9 & 14 & 36,8 & 0,853 \\
\hline Alugado & 17 & 58,6 & 21 & 55,3 & \\
\hline Ocupação/Albergue & 1 & 3,5 & 3 & 7,9 & \\
\hline \multicolumn{6}{|l|}{ Paga IPTU ${ }^{1,3}$} \\
\hline Não & 6 & 22,2 & 6 & 17,1 & 0,616 \\
\hline Sim & 21 & 77,8 & 29 & 82,9 & \\
\hline \multicolumn{6}{|c|}{ Número de pessoas com quem mora ${ }^{2}$} \\
\hline 0 & 11 & 37,9 & 13 & 34,2 & 0,607 \\
\hline 1 & 9 & 31,0 & 9 & 23,7 & \\
\hline 2 & 4 & 13,8 & 4 & 10,5 & \\
\hline 3 & 2 & 6,9 & 8 & 21,1 & \\
\hline$\geq 4$ & 3 & 10,4 & 4 & 10,5 & \\
\hline \multicolumn{6}{|l|}{ Chefe da família ${ }^{1,3}$} \\
\hline Próprio usuário & 19 & 70,4 & 27 & 77,1 & 0,546 \\
\hline Familiares/Amigos & 8 & 29,6 & 8 & 22,9 & \\
\hline \multicolumn{6}{|l|}{ Crença religiosa $^{1}$} \\
\hline Não & 14 & 48,3 & 12 & 31,6 & 0,165 \\
\hline Sim & 15 & 51,7 & 26 & 68,4 & \\
\hline \multicolumn{6}{|c|}{ Suficiência da renda para } \\
\hline \multicolumn{6}{|l|}{ Alimentação $^{2}$} \\
\hline Não & 2 & 6,9 & 2 & 5,3 & 1,000 \\
\hline Sim & 27 & 93,1 & 36 & 94,7 & \\
\hline \multicolumn{6}{|l|}{ Lazer $^{1}$} \\
\hline Não & 5 & 17,2 & 10 & 26,3 & 0,377 \\
\hline Sim & 24 & 82,8 & 28 & 73,7 & \\
\hline
\end{tabular}

Escola $^{1}$ 


\begin{tabular}{|c|c|c|c|c|c|}
\hline \multirow[t]{3}{*}{ Variáveis } & \multicolumn{5}{|c|}{ Adesão } \\
\hline & \multicolumn{2}{|l|}{ Não } & \multicolumn{2}{|l|}{ Sim } & \multirow[t]{2}{*}{$p$} \\
\hline & $\mathrm{N}=\mathbf{2 9}$ & $\%$ & $\mathbf{N}=\mathbf{3 8}$ & $\%$ & \\
\hline Não & 8 & 27,6 & 9 & 23,7 & 0,716 \\
\hline Sim & 21 & 72,4 & 29 & 76,3 & \\
\hline \multicolumn{6}{|c|}{ Vestuário $^{2}$} \\
\hline Não & 2 & 6,90 & 3 & 7,9 & 1,000 \\
\hline Sim & 27 & 93,1 & 35 & 92,1 & \\
\hline \multicolumn{6}{|l|}{ Saúde $^{1}$} \\
\hline Não & 9 & 31,0 & 6 & 15,8 & 0,138 \\
\hline Sim & 20 & 69,0 & 32 & 84,2 & \\
\hline \multicolumn{6}{|c|}{ Transporte $^{2}$} \\
\hline Não & 2 & 6,90 & 3 & 7,9 & 1,000 \\
\hline Sim & 27 & 93,1 & 35 & 92,1 & \\
\hline \multicolumn{6}{|c|}{ Cultura $^{2,4}$} \\
\hline Não & 1 & 3,5 & 1 & 2,6 & 1,000 \\
\hline Sim & 28 & 96,5 & 37 & 97,4 & \\
\hline \multicolumn{6}{|c|}{ Recebe benefício social ${ }^{2}$} \\
\hline Não & 27 & 93,1 & 36 & 94,7 & 1,000 \\
\hline Sim & 2 & 6,9 & 2 & 5,3 & \\
\hline \multicolumn{6}{|c|}{ Participação em grupos ${ }^{2,3}$} \\
\hline Não & 23 & 79,3 & 35 & 92,1 & 0,160 \\
\hline Sim & 6 & 20,7 & 3 & 7,9 & \\
\hline
\end{tabular}

${ }^{1}$ Teste qui-quadrado

${ }^{2}$ Teste Exato de Fisher

${ }^{3}$ Não foram obtidas informações para a totalidade dos usuários

${ }^{4}$ Acesso à internet, a livros e a revistas

A comparação das variáveis do processo de saúde-doença associadas com a adesão à PEP (Tabela 15) mostrou diferença em termo percentual da distribuição dos participantes do estudo em relação à adesão $(72,4 \%)$ ou à não adesão $(60,5 \%)$ segundo o uso de drogas, com concentração nos usuários que não as usavam no momento. A não adesão foi mais prevalente entre os usuários que iniciaram a PEP mais tardiamente, tiveram vontade de desistir de tomar o medicamento, e entre os usuários que não receberam informação sobre a PEP por meio de um profissional de saúde. Embora tenha ocorrido diferença de percentuais entre as variáveis, não houve diferença estatisticamente significante. 
Tabela 15. Distribuição dos usuários de acordo com as variáveis do processo de saúde-doença e correlação com a adesão. São Paulo, 2019.

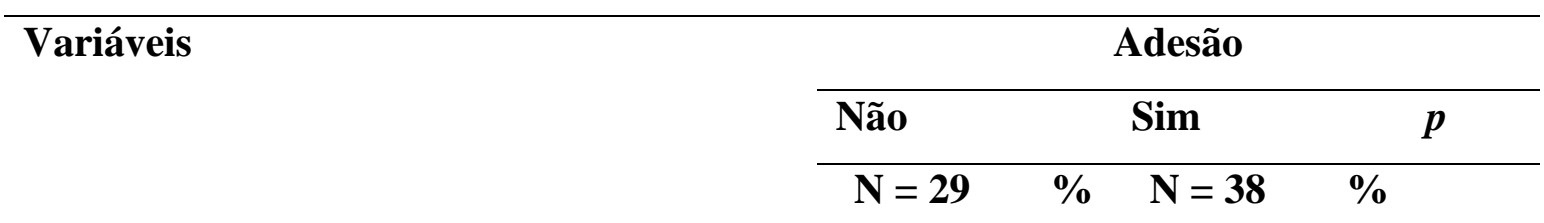

Uso de drogas no momento ${ }^{1}$

Não

Sim

Tempo da última exposição ao HIV (horas) ${ }^{2}$

$\leq 24$

$25 \dashv 48$

$49-72$

Uso de preservativo nas relações sexuais ${ }^{1}$

Não

Sim

Como obteve informação sobre a $\mathrm{PEP}^{2,1}$

Equipe de saúde

Propaganda sobre a PEP

Buscou informação sobre a PEP

Amigos

Número de vezes em que fez uso da PEP ${ }^{2}$

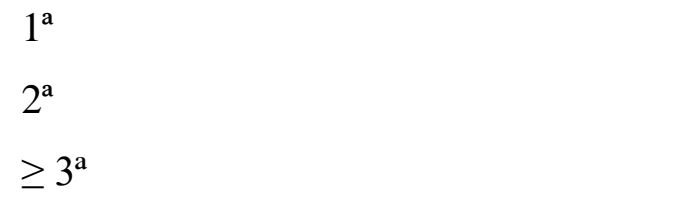

Tipo de prática sexual que indicou a $\mathrm{PEP}^{2,3}$

Anal ou vaginal

Oral

2392,0

28,0

$30 \quad 93,7 \quad 1,000$

Uso de preservativo na prática sexual que indicou a $\mathrm{PEP}^{1,3}$

Não

Sim

$16 \quad 64,0$

$18 \quad 56,2 \quad 0,554$

936,0

$14 \quad 43,8$

Conversou sobre o tratamento da $\mathrm{PEP}^{1}$

Não

$14 \quad 48,3$

$21 \quad 55,3 \quad 0,570$

Sim

$15 \quad 51,7$

$17 \quad 44,7$

Efeitos colaterais do medicamento ${ }^{1}$ 


\begin{tabular}{|c|c|c|c|c|c|}
\hline \multirow[t]{3}{*}{ Variáveis } & \multicolumn{5}{|c|}{ Adesão } \\
\hline & \multicolumn{2}{|l|}{ Não } & \multicolumn{2}{|l|}{ Sim } & \multirow[t]{2}{*}{$p$} \\
\hline & $\mathbf{N}=\mathbf{2 9}$ & $\%$ & $\mathbf{N}=\mathbf{3 8}$ & $\%$ & \\
\hline Não & 15 & 51,7 & 21 & 55,3 & 0,773 \\
\hline Sim & 14 & 48,3 & 17 & 44,7 & \\
\hline \multicolumn{6}{|c|}{ Teve vontade de desistir do medicamento ${ }^{2,3}$} \\
\hline Não & 24 & 82,8 & 35 & 97,2 & 0,081 \\
\hline Sim & 5 & 17,2 & 1 & 2,8 & \\
\hline \multicolumn{6}{|c|}{ Dificuldades para fazer uso do medicamento $^{1}$} \\
\hline Não & 24 & 82,8 & 29 & 76,3 & 0,561 \\
\hline Sim & 5 & 17,2 & 9 & 23,7 & \\
\hline
\end{tabular}

${ }^{1}$ Teste qui-quadrado

${ }^{2}$ Teste Exato de Fisher

${ }^{3}$ Não foram obtidas informações para a totalidade dos usuários

A comparação das variáveis do atendimento do serviço de saúde associadas com a adesão à PEP (Tabela 16) mostrou concentração na faixa maior do que duas horas em relação à permanência do usuário no serviço de saúde no baseline, com pequena diferença percentual entre os que não aderiram $(62,1 \% \%)$ e os que aderiram $(57,9 \%)$, sendo a não adesão mais prevalente entre os usuários que permaneceram por mais de duas horas no serviço. Para apenas um usuário, o serviço de saúde não atendeu às necessidades. Embora tenha ocorrido diferença de percentuais, não houve diferença estatisticamente significante.

Tabela 16. Distribuição dos usuários de acordo com as variáveis do serviço de saúde e correlação com a adesão. São Paulo, 2019.

Variáveis

Adesão

\begin{tabular}{lcccc}
\hline Não & & Sim & \multicolumn{1}{c}{$p$} \\
\hline $\mathbf{N}=\mathbf{2 9}$ & $\%$ & $\mathrm{~N}=$ & $\%$
\end{tabular}

38

Tempo de permanência no serviço de saúde (em

horas) durante o baseline ${ }^{1}$

$\begin{array}{lrrrrr}\leq 1 & 2 & 6,9 & 4 & 10,5 & 0,864 \\ 1 \dashv 2 & 9 & 31,0 & 12 & 31,6 & \\ >2 & 18 & 62,1 & 22 & 57,9 & \end{array}$

O serviço de saúde atendeu às necessidades ${ }^{1}$

Não

$\begin{array}{lllll}1 & 3,5 & 0 & 0,0 & 0,433\end{array}$ 
Variáveis

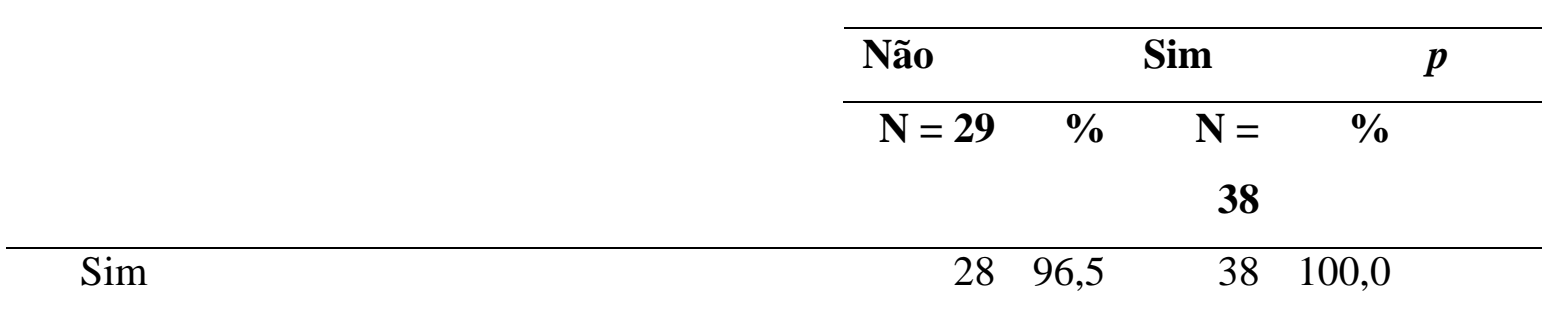

${ }^{1}$ Teste Exato de Fisher 


\section{DISCUSSÃO}

A presente investigação, realizada com os 91 usuários do SAE que foram indicados para PEP, mostrou que a maioria era do sexo masculino, $\mathrm{HSH}$, solteira com média de idade de 32,5 anos (variando de 18 a 59 anos), da cor branca e com nível superior ou pós-graduação. Essa caracterização sociodemográfica é similar à de estudos realizados em países desenvolvidos (Milinkovic, 2017; Thomas et al., 2015; Beymer, 2018). O resultado obtido pode estar refletindo o perfil dos usuários do serviço de saúde analisado, cuja maioria é composta por jovens, brancos, solteiros, com nível de escolaridade médio completo, moradores da região central, com alguma ocupação e trabalhando no centro da cidade (Dienno et al., 2010). Esses achados são semelhantes aos do perfil encontrado em outros serviços de aconselhamento e testagem para HIV/aids do estado de São Paulo (Farias et al., 2008). Entretanto, há que se considerar que há especificidade do perfil da população do estudo, possivelmente diferente em outras regiões do país.

Ao analisar o perfil dos usuários de serviços de saúde no SUS, é possível observar uma caracterização sociodemográfica diferente da dos achados no presente estudo, na qual há predomínio de mulheres, crianças, pretos e pardos, de baixas escolaridade e renda. O perfil encontrado neste estudo leva a questionar se as pessoas negras, com baixas escolaridade e renda, e em situação de rua estão tendo acesso aos serviços de saúde de testagem em HIV/aids, e em particular onde há PEP, pois justamente essa população é indicada pelo Ministério da Saúde como prioritária para as ações de prevenção ao HIV/aids (Brasil, 2017d).

Outro ponto que merece destaque é o baixo percentual de mulheres encontrado no estudo, semelhante ao de outras investigações em diferentes países da Ásia, da Europa e das Américas (Noam Oz, 2017; Malinverni et al., 2018; Thomas et al., 2015; Beymer et al., 2018). A reduzida procura da PEP por mulheres pode estar atrelada às barreiras no acesso relacionadas ao estigma que elas sofrem ao procurar um serviço de referência para IST particularmente quando é um serviço que trata de HIV/aids -, devido à associação com práticas sexuais e comportamentos moralmente condenados pela sociedade (Parker, 2001). Além disso, é possível que as mulheres continuem a não se ver vulneráveis ao HIV, como no início da epidemia (Santos, 2009), ainda que tenham se passado quase 40 anos desde a identificação do primeiro caso em mulher.

Considera-se que há a necessidade de investimentos em políticas de saúde voltadas para o público feminino que consigam diminuir as barreiras de acesso à PEP, pois, além da baixa procura, há pouco conhecimento sobre a profilaxia. Um estudo com registros de dois anos em cinco cidades brasileiras relatou que $25 \%$ dos usuários que buscam a PEP são 
mulheres; ademais, aquelas com nível superior e que tiveram relações com parceiros desconhecidos para risco do HIV tinham pouco conhecimento sobre o uso da profilaxia (Grangeiro, 2019).

Certa "invisibilidade" das mulheres em serviços de HIV/aids chama a atenção. Segundo Pires (2016), o olhar das políticas de saúde está focado à sua função reprodutiva e, mais ainda, para a mulher grávida, de tal maneira que muitas só são diagnosticadas com HIV no pré-natal ou no parto. O próprio ministério não considera as mulheres em geral como parcela prioritária das ações de controle para o HIV, focando em trabalhadores do sexo (Brasil, 2017d). De tal forma, as mulheres acessam mais frequentemente a PEP na condição de uma agressão sexual ou exposição ocupacional, inclusive por serem elas o maior contingente de trabalhadores da área da saúde, conforme mostrou o estudo de Bogoch (2014) e de Carneiro (2018).

Sobre o perfil dos usuários de PEP do estudo, em relação às formas de trabalhar, a maioria estava trabalhando, pouco mais da metade com registro em carteira de trabalho e em ocupações que exigiam qualificação. Segundo a classificação das ocupações descrita por Trapé (2011), ocupavam cargos mais elevados de planejamento e organização, empresariado, direção e gerência. Esse perfil de usuário encontrado neste estudo pode ser explicado, em parte, às características do território, pois identifica-se a valorização das residências na região central, onde está localizado o serviço de saúde - em um processo recente de reocupação da região, muitos empreendimentos imobiliários foram construídos nela, próximos aos centros comerciais e financeiros da cidade, atraindo adultos que vieram de regiões periféricas para morar sozinhos, mais próximos aos locais de trabalho (Paternak et al., 2014; Nakano, 2018). Quanto às formas de viver, também foi possível identificar que o acesso ao serviço se deu por indivíduos que moravam sozinhos, em casas alugadas, que pagavam IPTU e eram chefes de família.

Desse modo, o grupo que está acessando a PEP pode ser aquele que tem melhor inserção no sistema de produção e, consequentemente, na forma de viver, pois os resultados do presente estudo mostram que a maioria dos usuários referiu renda suficiente para alimentação, lazer, escola, vestuário, saúde, transporte e cultura - acessos que são alcançados com trabalho e renda. Esse perfil de usuário da PEP é similar ao de outro estudo (Landovitz, 2012). Os dados obtidos também podem estar refletindo o perfil geral de usuários que procuram serviços de referência em IST/HIV: jovens, com nível de escolaridade médio completo, morando na região central, com alguma ocupação e trabalhando no centro da cidade (Deienno, 2010). 
A região central também é constituída de moradias coletivas denominadas pensões, antigos cortiços que acomodam pessoas com condições precárias de trabalho, como observado em relação a outra parcela de usuários do serviço, cujas ocupações exigiam pouca ou nenhuma qualificação - parte deles em trabalho informal e precário, como as profissionais do sexo ou os vendedores ambulantes (Nakano, 2018).

A unidade de saúde onde foi realizado o estudo encontra-se localizada na região central do município, onde a prostituição, tanto a masculina como a feminina, é importante, além da existência nela de contingente de moradores de rua e de albergados e onde o consumo de drogas ilícitas é presente. No centro há concentração de ofertas de lazer e entretenimento (cinemas, bares etc.) e um grande número de instituições públicas de saúde, justiça e educação. Essa região recebe fluxo relevante de pessoas que trabalham e transitam em busca de trabalho, havendo entroncamento de linhas de metrô e ônibus concentradas nela. Essa população acessa o serviço de saúde em questão, mas em menor percentual, conforme o estudo identificou - maior percentual de usuários com melhor inserção no trabalho -, o que leva a questionar como vem se dando, de fato, o acesso dos que possuem ocupações mais precárias, aqueles em trabalho informal e que vivem em condições não ideais.

Outro achado que chamou a atenção é o número de usuários que haviam feito o uso da PEP, que fizeram uma nova PEP no mesmo acompanhamento ou que iniciaram a PrEP na vigência da PEP. No presente estudo, a maioria dos usuários estava fazendo uso da PEP pela primeira vez, mas uma parcela importante já estava na segunda ou mais vezes $(42,9 \%)$. Entre os 20 que fizeram uma nova PEP ou iniciaram a PrEP: 8 usuários finalizaram a PEP com a tomada de medicamentos e, no primeiro retorno, iniciaram nova PEP devido a nova exposição; outros 12, ao término da PEP, foram indicados para PrEP. São pessoas que estão se expondo a situações de risco ao vírus e outras IST de maneira contínua, sem o uso de preservativo, o que é preocupante. Esses achados foram similares aos de outros estudos, com uso recorrente e repetido de PEP (OZ, 2017; Milinkovic, 2017; Beymer, 2018).

Essa não é uma situação exclusiva de um serviço brasileiro. Estudo realizado na África do Sul mostrou a indicação de PEP sequencialmente a outra PEP (Hugo et al., 2016). Alertase que novas exposições durante o uso da PEP podem gerar falhas na profilaxia e, em consequência, infecção pelo HIV. Em um estudo realizado no Canadá, das 3.457 pessoas que fizeram o uso da PEP, 10 soroconverteram. Dessas, 9 relataram episódios de exposição sexual sem o uso de preservativo durante a adoção da profilaxia (Thomas et al., 2015). Além disso, uma preocupação gira em torno do emprego intermitente da PEP e de suas possíveis consequências, com a necessidade do acompanhamento das funções renais e hepáticas em usuários nesse uso contínuo. A questão é que não há, de fato, investigação e monitoramento 
das pessoas que fazem uso corrente e intermitente de PEP nos serviços de saúde, considerando-se, inclusive, que os usuários podem estar acessando diferentes e diversos serviços em cada ocasião de PEP.

A transição da PEP para a PrEP em usuários com episódios seguidos de possível exposição ao HIV pode diminuir o número de vezes em que essas pessoas fazem uso da PEP (Hugo et al., 2016) e garantir maior proteção efetiva contra o vírus, uma vez que na PrEP há indicação de uso contínuo do medicamento (Anderson et al., 2011). Em um estudo realizado com usuários que faziam a PEP, 75\% disseram que utilizariam a PrEP se estivesse acessível a eles, e 83,3\% relataram que continuariam fazendo o uso de preservativo concomitante a seu emprego (Hugo et al., 2016). Sobre essa última afirmativa, de que o uso do preservativo seria feito em associação à PrEP, ela é questionável, uma vez que a PrEP é indicada justamente para usuários que fazem parte de uma população-chave (gays, outros $\mathrm{HSH}$, pessoas trans, casais sorodiscordantes e profissionais do sexo) e não recorrem a preservativo ou têm dificuldade em seu uso (Brasil, 2018c).

Durante a realização da pesquisa, percebeu-se que o serviço de saúde não está conseguindo proporcionar essa transição de maneira imediata - de PEP para PrEP -, porque esta última ainda não se encontra plenamente ofertada, fazendo que os usuários tenham dificuldade de acesso, com uma fila de espera chegando a meses. Durante esse tempo de espera, é possível que haja nova exposição e seja necessário início de nova PEP. Portanto, é preciso repensar e implementar mais prontamente a oferta da PrEP. Ao mesmo tempo, são necessários estudos que investiguem essa alta demanda pela PEP e pela PrEP nos serviços de saúde de São Paulo - em especial, os contextos aos quais foram indicados PEP para usuários com episódios seguidos de exposição. Em casos como o de profissionais do sexo e casais sorodiscordantes, por exemplo, que têm frequente exposição sexual, não está sendo possível indicar PrEP de maneira imediata, dada a pouca quantidade de medicamentos e profissionais de saúde capacitados e que podem prescrevê-los. Está previsto que enfermeiros podem realizar abordagem sindrômica das IST e prescrever PEP e PrEP, uma vez que fazem parte do programa nacional e estão estabelecidos por meio de protocolos clínicos e diretrizes terapêuticas (Coren, 2019; Brasil, 2018b; Brasil, 2018c), o que ampliaria o acesso à profilaxia.

Outra preocupação é o aumento da resistência antimicrobiana ao HIV. Segundo a OMS, há tendência crescente de resistência do vírus às drogas disponíveis. Essa resistência ocorre quando há mutações virais em indivíduos que já recebem as drogas, como aqueles com histórico de ingestão de medicamentos do HIV e que são infectados por versões mais resistentes; pessoas com exposição prévia aos medicamentos, iniciando ou reiniciando o 
tratamento, como mulheres expostas aos medicamentos para prevenção da transmissão do HIV de mãe para filho; pessoas que receberam profilaxia, ou que reiniciaram o tratamento após interrupção (WHO, 2019).

Mais um dado que chama a atenção é que alguns dos usuários que buscaram PEP haviam tido alguma IST anterior, com destaque à sífilis. Um estudo realizado no Reino Unido teve resultado similar em relação às IST anteriores entre os usuários de PEP, com predominância da sífilis (Milinkovic, 2017). No presente estudo, identificou-se a presença de sífilis entre os entrevistados HSH. Pesquisas mostram que é alta a prevalência da doença nesse grupo (Zou et al., 2013; Zoni et al., 2012), chegando a 30\% em alguns países da América Latina (Pando et al., 2012). No Brasil, segundo pesquisa realizada em 10 cidades brasileiras, a chance de ocorrência dessa IST está em 14\% entre os HSH (Kerr et al., 2013).

O uso do preservativo não é realizado por quase a metade da população. Em estudo nacional, em que foram entrevistadas 12 mil pessoas entre 15 e 64 anos, os resultados mostraram que apenas $54 \%$ responderam terem feito o uso de preservativo em todas as relações sexuais nos últimos 12 meses, mostrando que os brasileiros estão encontrando dificuldades em seguir esse procedimento (Brasil, 2016).

No presente estudo, os usuários referiram acesso ao insumo pela rede pública, de maneira gratuita, ou em farmácias, por meio de compra. Embora a totalidade dos usuários tenha respondido que tinha acesso a preservativo, mais da metade disse não tê-lo usado durante a relação sexual para a qual foi indicada a PEP. Outros estudos tiveram resultados similares (Thomas et al., 2015; Mayer et al., 2017; McAllister et al., 2017).

O não uso do preservativo pode ser um fator preocupante, uma vez que a maioria dos usuários da pesquisa teve relação sexual com prática anal, tipo de relação com maior chance de infecção pelo HIV (Sultan et al., 2014). Com isso, é importante saber os motivos de os usuários não fazerem esse uso, substituindo-o pelo emprego profilático de medicamentos, como a PEP. Segundo Adam et al. (2005), pode estar ocorrendo um sentimento de "fadiga do preservativo" ou "fadiga da prevenção" do HIV. Essa vulnerabilidade ao HIV está atrelada a questões psicológicas e sociais, sendo um desafio para as políticas de saúde adotar medidas mais direcionadas e eficazes em relação à prevenção com o uso do preservativo (Adam et al., 2005).

Outra possibilidade do não uso do preservativo está associada ao consumo de drogas. Um estudo no Brasil realizado com turistas relata que o abuso de álcool e drogas aumenta a vulnerabilidade ao HIV por favorecer o não uso do preservativo durante as relações sexuais (Santos, 2007). É importante lembrar que a indicação da PEP compõe um conjunto de ações 
da "mandala de prevenção", que trata de prevenções indicadas de maneira combinada, sendo o uso de preservativo uma delas.

Um ponto a ser destacado na indicação da PEP é o tempo da suposta exposição ao HIV até o início da profilaxia, com a sugestão de iniciar o procedimento o mais precocemente possível, uma condição para sua eficácia (Tsai, 1998). Dessa maneira, estabeleceu-se um prazo de até 72 horas para que a profilaxia seja iniciada após a exposição (Brasil, 2018c). Logo, é de extrema importância que o usuário comece a profilaxia o mais rápido possível, uma vez que a eficácia do medicamento pode diminuir com o passar do tempo (Hinkin et al., 2006; Wade et al., 1998). O tempo da exposição até a chegada ao serviço de saúde, no presente estudo, foi menor do que 24 horas para quase a metade dos usuários, o que é um bom indicativo. Ainda assim, 30 usuários chegaram entre 25 e 48 horas e 17, entre 49 e 72 horas. Um estudo relatou que a média entre o tempo da exposição até o início da PEP foi de 37,8 horas (Landovitz, 2012). Em outra pesquisa, 34\% dos usuários iniciaram a PEP dentro das 24 horas após a exposição, 33\%, entre 24 e 48 horas; e 29\%, entre 48 e 72 horas (Beymer et al., 2018). No estudo de Beymer et al. (2018), quatro entre os sete usuários que soroconverteram para o HIV iniciaram a PEP 48 horas após a exposição.

Esses resultados mostram tanto a importância de o usuário saber que pode iniciar a PEP em até 72 horas depois da exposição como também que é preciso iniciá-la o quanto antes para diminuir as chances de soroconversão. No estudo, entre os 41 usuários que retornaram para realizar o teste rápido, nenhum soroconverteu para o HIV. Algumas análises tiveram resultados semelhantes em relação à não soroconversão para o HIV (Kahn et al., 2001; Sánchez et al., 2017). Entretanto, há os que mostraram resultados pelos quais os usuários relataram ter feito o uso correto do medicamento, sem outras exposições ao HIV, mas soroconverteram (Malinverni et al., 2016; Thomas et al., 2015). Esses estudos apontam que, apesar da PEP ser bastante eficaz, pode envolver falhas.

Como muitas exposições podem ocorrer aos finais de semana - no estudo, quatro usuários iniciaram PEP em serviços que funcionam nessa condição -, é importante que o usuário tenha informação sobre os locais que atendem a PEP nesses dias, para que não espere o próximo dia útil a fim de iniciar a profilaxia em um serviço especializado em IST. Essas informações podem ser mais bem difundidas nas redes sociais e nos veículos de comunicação.

Em relação ao conhecimento dos usuários sobre as formas de transmissão do HIV e as consequências do vírus no corpo humano, praticamente a totalidade dos entrevistados conhecia as formas de transmissão e entendia a relação sexual como a principal delas. A respeito das consequências do HIV no corpo humano, a maioria relatou queda da imunidade. 
Ainda assim, 5 usuários disseram não ter nenhum conhecimento sobre como o vírus é transmitido e 19 não sabiam o que ele pode causar no corpo humano. Menor conhecimento sobre a doença pode tornar uma pessoa mais vulnerável à infecção e a toda uma comunidade (Almeida, et al., 2017). Em um estudo realizado no Rio de Janeiro, mais da metade dos participantes desconhecia a transmissão do HIV por sexo oral e por prática anal (Edmundo, 2007). Menor conhecimento sobre a transmissão do HIV está associado a menores escolaridade e renda - condição brasileira em destaque - e, para ampliar o conhecimento, é necessário maior investimento em políticas públicas de educação formal e desenvolvimento social (Mendes et al., 2017).

O foco principal deste estudo, a adesão, é considerada como o uso do medicamento por pelo menos 27 dias e com ao menos um retorno ao serviço de saúde, que foi de 56,7\%. Esse valor de adesão foi próximo ao encontrado em um estudo de meta-análise de adesão global $-56,5 \%$ (Ford et al., 2014).

Outros estudos encontraram um índice maior de adesão, considerando diferentes critérios e métodos para a medida dela. Em uma análise no Reino Unido, a adesão foi verificada por autorrelato sobre a tomada do medicamento e a contagem dos comprimidos nos dias 14 e 28, com percentual de 77\% e 82\% para o índice de adesão nas duas composições de medicamentos oferecidos (Milinkovic et al., 2017). Em outro estudo realizado na Bélgica, $87,3 \%$ compareceram a sua primeira consulta clínica e 66,4\% concluíram os 28 dias da profilaxia (Malinverni et al., 2018).

No Canadá, Thomas et al. (2015) estabeleceram um critério predeterminado para definir a adesão: os usuários que deixaram de tomar o medicamento por mais de cinco dias foram considerados não aderentes. Com esse critério, a adesão foi de $69 \%$ em relação à tomada do medicamento. Na Austrália, um estudo avaliou a adesão por meio da contagem de comprimidos que o usuário deixou de tomar, divididos pela quantidade dispensada. Esse trabalho indicou alto índice de adesão: 92\% para os usuários com 3 medicamentos prescritos e 91\% para os que tinham apenas 2 medicamentos prescritos (McAllister et al., 2014).

Outras investigações mostraram resultados que se aproximam dos encontrados no presente estudo em relação à adesão ao medicamento. Nos EUA, um estudo no qual a adesão foi medida por autorrelato do uso do medicamento na segunda e na quarta semanas, $53 \%$ dos usuários foram considerados aderentes (Beymer et al., 2018). Os índices de retorno foram diferentes dos da presente investigação, com $87 \%$ dos usuários tendo voltado em pelo menos um retorno (Beymer et al., 2018). Em outro trabalho, na África do Sul, 58,5\% dos usuários relataram ter feito uso completo do medicamento (Hugo et al., 2016). 
Esses resultados mostram que há diversos critérios estabelecidos em relação à adesão à PEP, com alguns estudos aferindo apenas a tomada do medicamento, e outros, o retorno. Talvez haja a necessidade de instrumentos e/ou escalas padronizadas para aferir a adesão à PEP, que considerem tanto a tomada do medicamento como o retorno de acompanhamento, uma vez que é no retorno que se tem a oportunidade de realizar aconselhamentos a pessoas com maiores chances de infecção (Malinverni et al., 2018). O estudo de Silva (2018) sugere a utilização de uma escala para avaliar a adesão à PEP de usuários do serviço de saúde após exposição sexual, chegando a validar o conteúdo, a face e o constructo - mas ainda é preciso que os resultados sejam confirmados por meio de outra amostra de validação e reespecificação.

O presente estudo mostrou ser baixo o número de usuários que retornam ao serviço, com diminuição percentual no segundo e no terceiro momentos. Uma pesquisa de acompanhamento de usuários indicados à PEP no Ceará, em situações de exposição sexual e outras, considerando quatro retornos, encontrou 30,8\% no primeiro retorno, $16,7 \%$ no segundo, caindo para 9,8\% no terceiro (Carneiro et al., 2018), o que mostra que, ao longo do tempo, há diminuição de comparecimento aos retornos. Essa não é uma característica exclusiva entre os usuários de PEP brasileiros, pois estudo no Canadá mostra o mesmo fenômeno (Bogoch et al., 2014).

A constatação de que poucos usuários retornam para o acompanhamento após a tomada do medicamento no serviço é preocupante, ainda mais no primeiro retorno (30 dias), uma vez que há chance de haver soroconversão quando ocorrem outras exposições durante a tomada do medicamento, o que pode diminuir a eficácia da PEP (Thomas et al., 2015). Além disso, é conveniente lembrar da importância do segundo retorno (90 dias), porque nele é refeita o teste rápido para hepatites, cuja janela imunológica é de maior tempo que a do HIV (Brasil, 2005).

No Brasil, em uma pesquisa realizada na cidade de Belo Horizonte, a adesão foi investigada em duas perspectivas: em relação ao uso correto do medicamento por 28 dias, com índice de adesão em 33,6\%, e em relação aos retornos ao serviço de saúde para realização dos exames de testagem, com índice de adesão em 6,8\% (Liza, 2019). Em outro estudo na cidade de Fortaleza, em que a adesão foi investigada pelos retornos, apenas 30,8\% dos usuários voltaram no segundo retorno (Carneiro et al., 2018). Na cidade de Curitiba, outra investigação teve como critério o retorno em 30 dias e o uso correto do medicamento. Ela obteve índice de adesão em 62,02\% (Silva, 2018).

Quanto aos retornos dos usuários aos serviços de saúde, no presente estudo, quando foi realizado um contato por meio de ligação telefônica, foi perguntado sobre os motivos da 
ausência ao serviço dessa natureza. Para a maioria, o fato de estar trabalhando e o esquecimento da consulta foram os motivos mais relatados. No momento 1, 55,9\% dos usuários relataram que não realizaram o retorno por conta do trabalho e 11,8\%, por ter esquecido do retorno; no momento 2 esse percentual foi de 48,5\% em relação ao trabalho e de 18,2 por esquecimento. Os SAE são serviços especializados que fazem o atendimento de segunda a sexta e em horário comercial, restrição que torna difícil ao usuário realizar o retorno. Essa é uma questão de difícil resolução, sendo um problema identificado em discussões de ampliação do acesso aos serviços de saúde na cidade. A modificação no horário implica reorganização da rede de atenção, com planejamento e orçamento para ampliação, condições essas ainda não previstas.

Em relação ao esquecimento da consulta de retorno, segundo Lima et al. (2018), um canal aberto entre os profissionais de saúde e o usuário do serviço promove maior acessibilidade e proporciona uma comunicação aberta e imediata. Além da orientação do profissional que atende o usuário, tem sido interessante o uso da tecnologia de aplicativos com avisos e lembretes quanto às datas de retorno e tomada do medicamento. Um estudo mostrou aceitação de aplicativos relacionados ao HIV pelos usuários e profissionais de saúde, aplicativos esses com função informativa e com lembretes aos usuários dos serviços quanto à agenda de retornos - alguns são produzidos inclusive no Brasil pelas secretarias municipal e estadual de saúde (Barbosa et al., 2019). De toda maneira, é um desafio à política o estabelecimento do vínculo do usuário com os serviços de saúde, buscando garantir a adesão à PEP e às demais ações previstas na prevenção combinada.

Ademais, outro motivo da ausência dos usuários nos serviços de saúde pode estar atrelado a não conversar sobre a PEP com outras pessoas. No presente estudo, parcela pequena dos usuários falou a respeito da PEP com algum familiar, amigo ou colega. Isso pode estar relacionado ao fato de que tomar um medicamento antirretroviral e fazer uso de um serviço de saúde que trata de pessoas vivendo com HIV/aids talvez traga estigmas que ainda são perpetuados na sociedade. Segundo Ferraz (2018), os diferentes cenários que levam ao uso da PEP ainda têm um expressivo estigma em relação à aids, gerando baixo conhecimento e dificuldade para se fazer o emprego da profilaxia. Segundo Grangeiro et al. (2019), o usuário tem maior chance de perda de acompanhamento quando faz uso da PEP em um serviço de saúde que trata o HIV/aids, em comparação com aqueles que buscam a PEP em um serviço voltado apenas para testagem e aconselhamento.

No presente estudo, quanto às características sociodemográficas, não foi encontrada associação estatisticamente significante com a adesão; entretanto, houve diferença de percentual entre as variáveis, e algumas chamaram a atenção. Os usuários que aderiram 
menos foram do sexo feminino, com idade entre 25 e 44 anos, da raça preta, com ensino superior e pós-graduação e HSH.

Menor adesão à PEP por usuários do sexo feminino também foi encontrada em outros estudos (Malinverni et al., 2018; Bogoch et al., 2014). É possível que esses resultados estejam relacionados às barreiras ainda prevalentes. Uma investigação mostrou que mulheres têm dificuldades em fazer uso de medidas de prevenção ao HIV, como o gel e os ARV, pois encontram barreiras sociais e culturais relacionadas ao gênero e ao estigma (Geary et al., 2014). Medidas de tecnologias para prevenção do HIV podem ser mais eficazes com pessoas do sexo feminino quando, ao mesmo tempo, forem implantadas políticas que busquem por igualdade social e por igualdade de gênero (Geary et al., 2014).

Quanto à maior adesão de usuários entre 25 e 44 anos, houve divergência em outras pesquisas, que apontaram maior adesão de usuários que tinham idade mais avançada (Thomas et al., 2015; Liza, 2019). Esses resultados podem estar atrelados ao fato de que, no presente estudo, só dois usuários tinham 45 anos ou mais, ficando a faixa etária concentrada em jovens e jovens adultos.

Sobre a menor adesão de usuários negros, foram encontrados resultados similares em outro estudo. Segundo Grangeiro (2019), aumenta em 1,13 a probabilidade de perda de acompanhamento da PEP quando a mulher é da cor preta. Ademais, essa cor é associada com piores condições socioeconômicas, menor oportunidade de ser atendido por um profissional de saúde, menor conhecimento sobre o que diz o médico infectologista durante as orientações e pouco conhecimento sobre exames para HIV/aids (Lopes et al., 2007), o que pode tornar essas pessoas vulneráveis ao vírus. Nas discussões de Santos (2009) e Barbosa (2003), pessoas vivendo com HIV/aids associam-se com menor escolaridade. Essas condições indicam que o modo como esses usuários estão inseridos na sociedade pode torná-los mais passivos em relação à adesão ao medicamento, transformando-os, então, em menos aderentes (Bertolozzi, 2009).

Em referência à menor adesão entre os usuários com maior escolaridade, outra investigação teve resultado divergente. Em um estudo realizado nos EUA, usuários com nível superior foram mais propensos a retornar ao serviço de saúde (Beymer et al., 2018). Esses resultados necessitam de melhores investigações. É possível que no SAE onde foi realizada a investigação do presente estudo os usuários mais escolarizados acessem a PEP, mas não consigam cumprir a profilaxia. Com isso, ao mesmo tempo que devem pensar nas políticas de acesso, é preciso preocupar-se com os usuários que acessam, são escolarizados, mas não são aderentes à profilaxia. 
No caso de menor adesão à PEP entre os HSH no presente estudo, há divergência dos resultados encontrados em outras pesquisas (Malinverni et al., 2018; Ford et al., 2014). Entretanto, segundo Malinverni (2018), uma maior adesão a PEP de HSH pode estar relacionada a uma melhor percepção nesse grupo em fazer o uso da profilaxia. As políticas atuais de prevenção ao HIV nesse grupo parecem ser insuficientes, ou aplicadas de maneira que não conseguem atender às necessidades de saúde no país. No Brasil, é alta a prevalência do HIV entre os HSH. Um estudo em 12 cidades brasileiras mostrou que 1 a cada 5 HSH estavam infectados com HIV (Keer et al., 2018). Ainda que esse grupo seja considerado população-chave pelo Ministério da Saúde (Brasil, 2017d), necessita de ações mais efetivas ao combate do HIV para que obtenham melhores resultados em relação à prevenção da doença.

No presente estudo, quanto às variadas formas de trabalhar associadas com a adesão, houve diferença percentual entre as variáveis, e algumas delas chamam a atenção - por exemplo, nos casos dos usuários que não estavam trabalhando, tinham curso preparatório para o trabalho (quando os usuários eram os chefes da família), apresentaram registro em carteira, exerciam cargos que necessitavam de qualificação na execução e recebiam benefícios referentes ao trabalho, como plano de saúde e cesta básica, sendo menos aderentes à PEP. Ademais, houve evidência de associação entre plano de saúde e adesão - pacientes sem plano de saúde aderiram mais do que aqueles com plano.

Em relação à menor adesão entre usuários que não tinham trabalho, um estudo nos EUA teve resultados similares (Beymer et al., 2018). Esse resultado nos chama a atenção pelo fato de, ao não trabalhar, o usuário estar em condições financeiras desfavoráveis, o que pode ocasionar inserção na sociedade que interfira no retorno ao serviço de saúde, pelos gastos com transporte e alimentação.

Em referência à maior prevalência de não adesão entre os usuários que tinham carteira assinada, curso preparatório para a ocupação, recebiam benefícios referentes ao trabalho e ocupavam cargos que exigiam qualificação na execução, esses resultados podem ter sido influenciados pela inserção no trabalho - trabalhadores com registro em carteira podem encontrar maior dificuldade em se ausentar do trabalho. Entre os que não retornaram após tentativa de contato telefônico, a maioria relatou que o motivo da ausência foi o trabalho. Pode haver um grau de importância e dependência do trabalho que interfira no cuidado de saúde dos usuários que fazem uso da PEP. Ademais, entregar um comprovante no trabalho para justificar a ausência pode ser desencorajador, pelo fato de que essa ação denuncia que o usuário está em um serviço de saúde que trata HIV/Aids, podendo sofrer estigma e 
preconceito. Dessa forma, uma flexibilidade no horário de atendimento do SAE, que não abre aos finais de semana, poderia aumentar a adesão entre usuários que trabalham.

Entretanto, indaga-se sobre outro motivo que pode ter influenciado esses trabalhadores a não voltarem ao serviço de saúde. Embora essa parcela da população possua uma inserção na sociedade relativamente favorável - trabalham e são escolarizados -, ainda assim não estão inseridos no estrato social mais rico da população e com acesso amplo à saúde. Logo, dependem, em parte, do serviço público de saúde para acessar um medicamento custoso e emergencial, mas não para realizar exames de acompanhamento.

Quanto à menor adesão de usuários que tinham o plano de saúde, um estudo na Bélgica e outro nos EUA mostraram resultados divergentes. Em ambos, os usuários que não tinham plano de saúde e pagavam por suas consultas foram menos aderentes que aqueles que tinham plano de saúde e não necessitavam pagar pelo acompanhamento (Malinverni et al., 2018; Bogoch et al., 2014). Como o presente estudo foi realizado em um país onde a PEP é fornecida de maneira gratuita pelo SUS e não há a necessidade de realizar o pagamento para fazer a profilaxia, é possível que os usuários com plano de saúde tenham retornado a um serviço particular para realizar a testagem.

No presente estudo, para as variadas formas de viver não foi encontrada associação estatisticamente significativa com a adesão, mas algumas variáveis chamaram a atenção. Houve diferenças percentuais com menor adesão entre os usuários que não tinham renda suficiente para saúde, não tinham crença religiosa e participavam de algum grupo ligado ao trabalho, à igreja, ao trabalho voluntário ou a amigos de bairro.

Em referência à menor adesão de usuários com renda insuficiente para saúde, é possível que esse aspecto esteja ligado a piores condições socioeconômicas, a tornar esses usuários mais vulneráveis ao HIV. O Ministério da Saúde não considera grupos com condições econômicas desfavoráveis como população-chave no combate ao vírus (Brasil, 2017d), entretanto, pessoas nessas condições encontram maior dificuldade para aderir a métodos de prevenção (Zucchi et al., 2018). A fim de que as ações de saúde consigam abarcar as necessidades desse grupo, é necessário um olhar para além do risco e mais voltado às vulnerabilidades (Ayres, 2002). Ademais, a renda insuficiente e a vulnerabilidade desses usuários decorrem do modo como eles estão inseridos na sociedade. De acordo com Bertolozzi (2009), quando usuários estão expostos a processos de desgaste, a inserção determina o acesso a condições de vida e ao enfrentamento da doença, o que pode culminar em melhor adesão.

Quanto à menor adesão de usuários que não tinham alguma crença religiosa, outros estudos já mostraram que essa condição pode interferir na adesão aos ARV e na qualidade 
de vida de pessoas vivendo com HIV (Araujo et al., 2012). Existem relatos de que a crença para essas pessoas seja um potencial de fortalecimento e de ajuda no enfrentamento do processo de saúde no qual estão inseridas. Segundo Russell (2003), a tomada de decisão sobre o uso de medicamentos é complexa e abrange a crença em facilitadores que envolvem a questão de vida e o tratamento, que, por sua vez, são influenciados pela crença.

Em relação ao maior percentual de não adesão entre usuários que participavam de algum grupo, esse resultado foi diferente do de outros estudos que investigaram a adesão aos ARV entre pessoas vivendo com HIV em associação com a rede social do usuário do serviço de saúde (Silva et al., 2009; Santos et al., 2011). Esse resultado pode estar atrelado ao fato de que os usuários da PEP encontram barreiras de apoio para conversar com outras pessoas, ou nos grupos sociais em que estão inseridas. No presente estudo, a maioria dos entrevistados não falou com ninguém sobre o uso da PEP, talvez pelo fato de que a utilização de medicamentos durante a PEP fosse por um curto período de tempo, logo, não valeria a pena a exposição para não sofrer com estigma e preconceito. Portanto, é possível que os usuários que fazem uso de PEP e estão inseridos em algum grupo não estão conseguindo recorrer a esse potencial de fortalecimento como um apoio a melhorar a adesão.

No presente estudo, em relação às variáveis do processo de saúde, não foi encontrada associação estatisticamente significante com a adesão, entretanto, algumas variáveis chamaram a atenção e tiveram diferenças percentuais. Foram menos aderentes os usuários que tiveram vontade de desistir de tomar o medicamento, que receberam informações sobre a PEP de outros meios que não os profissionais de saúde e que iniciaram a PEP mais tardiamente.

Os usuários responderam que a vontade de desistir de tomar o medicamento foi por acharem que esse procedimento não valeria a pena por conta dos efeitos colaterais ou porque sentiram vontade de ingerir bebida alcoólica. Uma oportunidade para conversar com os usuários sobre esses dilemas e explicar a respeito da importância de finalizar a PEP ocorre durante o aconselhamento. Segundo Araújo, Bucher e Bello (2004), o aconselhamento é individual e, além de melhorar a adesão aos retornos e ao medicamento, é peça essencial no controle de transmissão das IST. Quanto aos usuários que iniciaram a PEP em menor tempo, é possível que esses indivíduos tenham um melhor entendimento sobre o processo de saúde, o que os torna mais ativos no processo (Bertolozzi, 2009); consequentemente, eles buscam a PEP mais precocemente e se preocupam em realizar os retornos ao serviço de saúde.

Em referência aos usuários que souberam da PEP por meio de um profissional de saúde, eles podem ter recebido informações relevantes e mais confiáveis sobre a importância de tomar os medicamentos e realizar os retornos ao serviço de saúde, o que talvez tenha 
influenciado um melhor entendimento do processo de saúde que estavam enfrentando no momento. Com isso, Oz (2017) indaga se essas explicações detalhadas sobre a importância do cumprimento da profilaxia contribuem para uma melhor adesão.

No presente estudo, em relação à variável atendimento do serviço de saúde, não foi encontrada associação estatisticamente significante com a adesão, entretanto, houve diferença no percentual em relação ao tempo de permanência do usuário no serviço de saúde. A não adesão foi mais prevalente entre os usuários que permaneceram por mais tempo no serviço de saúde, e para apenas um usuário o serviço de saúde não atendeu às necessidades.

Nesse sentido, é importante destacar que o usuário, em busca da PEP, necessita ser atendido de maneira emergencial, uma vez que as chances de soroconversão aumentam quando a PEP é iniciada mais tardiamente (Brasil, 2018c). Um estudo em Israel mostrou que os usuários esperavam por um longo período para ser atendidos por um médico, e isso poderia fazê-los pensar que a espera os obrigaria a começar o tratamento mais tarde do que o recomendado pelas diretrizes $(\mathrm{Oz}, 2017)$. A demora no atendimento pode trazer angústias e medo quando o usuário tem conhecimento sobre a necessidade de iniciar a profilaxia mais rapidamente.

Considera-se ser esse um indicativo de qualidade no atendimento: quanto menor o tempo, com orientações corretas, melhor para o usuário. Para a maioria dos usuários, no primeiro atendimento, o tempo foi maior que 2 horas, com o máximo entre 5 e 6 horas (tempo no baseline), o que pode ser considerado extensivo, dado que a PEP deve ser indicada o mais precocemente. Em um estudo realizado na Austrália, a média de horas em que a PEP foi iniciada após a apresentação do usuário ao serviço de saúde foi de até 2 horas (Foster et al., 2015). Identificar se o usuário necessita fazer uso da PEP e saber o tempo da exposição já no primeiro contato pode ser crucial para a prescrição da PEP antes das 72 horas. Nesse sentido, é importante a revisão do fluxo e a organização do serviço para que o atendimento tenha prioridade, a depender do intervalo entre o horário da exposição e a chegada à unidade de saúde.

Em relação ao atendimento do serviço de saúde, no presente estudo o tempo pelo qual o usuário permaneceu no serviço foi diminuindo conforme os retornos. Esse resultado pode ser pelo fato de que, no momento 1 e no momento 2, o usuário não passa por consulta médica e não retira medicamentos na farmácia, apenas realiza o teste rápido e a consulta com o profissional aconselhador. Justamente no momento de realização do teste rápido decorreu o maior número de horas. Isso pode estar atrelado ao pequeno número de profissionais que realizam esse teste no serviço de saúde - normalmente, enfermeiros, que também desempenhavam outras funções. Ainda que tenham tido maior tempo despendido nesse 
momento, quase a totalidade dos usuários relatou que suas necessidades quanto ao que procurava foram atendidas no serviço de saúde graças ao bom atendimento dos profissionais - por receber medicamentos ou porque foi o que esperava do serviço de saúde. Apesar do tempo pelo qual os usuários ficaram no serviço até conseguir iniciar a PEP, parece que houve um entendimento por parte deles de que os profissionais estão desempenhando bem as funções de atendimento.

Ademais, é possível que os usuários tenham se ausentado do trabalho para iniciar a PEP e, com isso, optaram por não fazer o retorno para não ter mais ausências. Uma opção do serviço é disponibilizar o autoteste e pedir para o usuário testá-lo depois de 30 dias em sua casa. Porém, é preciso relativizar esse procedimento, pois, além de retirar a importância do serviço de saúde, o usuário pode soroconverter e não ter um profissional para auxiliá-lo nesse momento. Também, como o autoteste é apenas para o HIV, as outras IST poderiam não ser diagnosticadas. Portanto, como a falta no trabalho nem sempre é uma opção para o usuário, é preciso que o serviço de saúde trabalhe no sentido de melhorar o atendimento da PEP, visto a importância em realizar uma profilaxia que pode impedir a infecção pelo HIV.

Quanto ao serviço não ter atendido às necessidades, os atendimentos da PEP nos serviços de saúde especializados devem ir além de oferecer os medicamentos e monitorar os efeitos colaterais. É preciso usar essa oportunidade atentando-se para que usuários em vulnerabilidade social (Malinverni et al., 2018) recebam aconselhamento com explicações sobre a importância da PEP e tenham atendimento em um ambiente discreto e confortável para melhorar a adesão (Oz, 2017).

Em relação às contribuições do estudo para a enfermagem, os currículos de graduação, a pesquisa e a assistência: no caso da enfermagem, entende-se a necessidade de que ela compreenda que os condicionantes podem interferir na adesão, tanto em relação à ingestão dos medicamentos como sobre os retornos do usuário ao serviço de saúde. Uma vez que os condicionantes são entendidos como parte do processo de adesão à PEP, é possível aplicálos junto às práticas da profissão da enfermagem, para que não se atue de maneira voltada, apenas, para a realização de exames de teste rápido e a entrega dos medicamentos. $\mathrm{O}$ aconselhamento, parte do processo da política da PEP, pode ser uma oportunidade para desenvolver essa abordagem, uma vez que é realizada uma consulta individual com os usuários, tanto no dia da indicação da PEP como nos dois retornos subsequentes. Quanto aos currículos de graduação, é importante que o aluno de enfermagem tenha contato com esses serviços de saúde e com prevenções voltadas para o HIV/Aids, uma vez que a PEP ainda é pouco conhecida, até entre os próprios profissionais de saúde; ademais, ele deve entender os aspectos de vulnerabilidade dos usuários que fazem a PEP, como as profissionais do sexo, 
HSH e pessoas trans, e enxergar a PEP como uma alternativa para usuários vulneráveis que não conseguem recorrer a preservativos - pode ser uma forma de o aluno se preparar para atuar nessa prática, e também uma maneira de ele ver como trabalhar com preconceitos e estigmas que ainda ocorrem em serviços de saúde que tratam o HIV/aids. Em relação à pesquisa, o estudo mostra que ainda existem barreiras de acesso à PEP para pessoas negras, mulheres e indivíduos com baixa escolaridade, o que pode ser mais bem estudado em pesquisas futuras. Há caminhos que precisam ser percorridos. Pesquisas de intervenção que possam criar mecanismos para contribuir à melhor adesão à PEP por meio de tecnologias que considerem a inserção do usuário na sociedade podem ser exploradas. Por fim, na assistência, entende-se que aquela concedida aos usuários durante a PEP é, em sua maioria, realizada por profissionais da enfermagem, visto que eles fazem a coleta de sangue e, muitas vezes, também realizam o procedimento do teste rápido e o aconselhamento. Dessa forma, ter um enfermeiro nos serviços de saúde responsável por essa política é uma opção para melhorar a assistência e ter resultados positivos em relação à busca ativa dos usuários que não realizam os retornos, podendo aumentar a adesão à PEP.

Em síntese, ao se analisar a adesão à profilaxia antirretroviral de risco para a infecção do HIV em usuários de um serviço de atenção em HIV/aids no município de São Paulo, com a PEP como uma ação de prevenção inserida no âmbito das diretrizes das políticas públicas em HIV/Aids, considera-se que há fragilidades que interferem no cumprimento efetivo do protocolo (Brasil, 2018c), uma vez que é baixo o número de usuários que fizeram os dois retornos após a indicação e a dispensação do medicamento. 


\section{CONCLUSÃO}

A avaliação sobre a adesão a PEP mostrou que, conforme apresentado na introdução, são poucos os estudos publicados sobre a adesão à PEP por exposição sexual ao HIV. O foco de avaliação dos estudos esteve centrado na tomada dos medicamentos; poucos retratam a adesão relacionada às formas de como o usuário do serviço de saúde está inserido na sociedade, como ele trabalha, vive, entende o processo de saúde, ou como estão organizados os serviços que fazem o seu atendimento. No Brasil, a literatura ainda é escassa e, na revisão da literatura, não foi encontrado estudo de coorte com dados primários no país.

O acesso a PEP ainda está atrelado, em sua maioria, aos usuários da cor branca, escolarizados, com idade entre 29 e 44 anos, e HSH. Portanto, ainda existe barreiras de acesso às políticas de saúde para populações específicas, por exemplo, em usuários com pior inserção social tanto nas formas de viver como no trabalho; que vivem em situação de rua, adolescentes e pessoas do sexo feminino.

Em relação à adesão a PEP, verificou-se que é alta a adesão em relação ao uso do medicamento, mas ela diminui ao se analisar os retornos de acompanhamento. Poucos usuários retornam para fazer a testagem sorológica, 30 dias após a exposição, e um número ainda menor realiza o último retorno, de 90 dias após o início da profilaxia. Portanto, como o serviço de saúde não realiza um rastreamento dos usuários que fazem o uso da PEP, não há informação daqueles que não retornam, em relação ao uso do medicamento e, se houve, ou não, a soroconversão para o HIV ou infecções por outras IST, como as hepatites e a sífilis.

No que se refere às características sociodemográficas, modos de viver, modo de trabalhar, processo de saúde e atendimento do serviço, apenas a variável "plano de saúde" mostrou-se estatisticamente significante em associação com a adesão (p < 0,05). Entretanto, outras variáveis, que não tiveram associação estatisticamente significante $(\mathrm{p}<0,2)$ devem ser destacadas como possíveis condicionantes que podem favorecer ou não a adesão à profilaxia. Nesse sentido, os condicionantes que desfavoreceram a adesão à PEP foram: ocupação no trabalho que exige alguma qualificação (usuários que ocupam cargos qualificados na execução), acesso a benefícios provenientes do trabalho (vale-refeição, valetransporte e plano de saúde), não ter renda suficiente para saúde e participar de algum grupo associativo. E os condicionantes que favoreceram a adesão à PEP foram: presença de alguma crença religiosa, iniciar a PEP mais precocemente após suposta exposição pelo HIV e receber informação sobre a PEP pela equipe de saúde.

Percebe-se que a PEP não está sendo usada apenas em casos de emergência ou em exposições esporádicas. Os usuários estão fazendo uso seguido da profilaxia devido a 
recorrentes práticas sexuais sem uso do preservativo, e com risco de exposição ao HIV e/ou pela dificuldade de acessar a PrEP no serviço de saúde. Desse modo, há um problema referente a essas prevenções, uma vez que a PEP está sendo usada de maneira a substituir a PrEP, mas sem acompanhamento das funções renais e hepáticas dos usuários do serviço de saúde.

Espera-se que os resultados do presente estudo possam contribuir para melhor adesão à PEP de usuários do serviço de saúde, como também mostrar a importância de que a adesão possa ser entendida não apenas quanto ao uso do medicamento, mas que depende de um contexto ao qual o usuário do serviço de saúde está inserido. Portanto, é imprescindível que os serviços de saúde considerem as vulnerabilidades dos usuários indicados como parte do processo de adesão, e que os profissionais responsáveis pela assistência, especialmente a enfermagem, tenham conhecimento sobre os condicionantes que envolvem a adesão à PEP para assegurar um plano de cuidado individualizado ao usuário, conforme suas necessidades de saúde.

Como limitação do presente estudo há: a adesão ao medicamento foi avaliada por meio das respostas do usuário (autorreferida), ou por informações anotadas no prontuário do usuário pelo profissional de saúde; foi analisado apenas um serviço de saúde de uma região do município de São Paulo; e foi feito um recorte de um período específico. Outros meios, como a contagem de comprimidos, monitorização e/ou biomarcadores por meio da pílula eletrônico, podem avaliar adesão sob outras perspectivas, além da análise comparativa entre diferentes serviços de saúde especializados, nas diversas regiões do município, e abranger um período maior para coleta dos dados. Com isso, ressalta-se a necessidade de mais estudos que possam preencher as lacunas aqui deixadas. 


\section{REFERÊNCIAS}

Adam BD, Husbands W, Murray J, Maxwell J. Aids optimism, condom fatigue, or selfesteem? Explaining unsafe sex among gay and bisexual men. J Sex Res. 2005;42(3):238-48.

Almeida RAA, Corrêa RGCF, Rolim ILTP, Hora JM, Linard AG, Coutinho NPS, et al. Conhecimento de adolescentes relacionados às doenças sexualmente transmissíveis e gravidez. 2017;70(5):1087-94.

Anderson PL, Kiser JJ, Gardner EM, Rower JE, Meditz A, Grant RM. Pharmacological considerations for tenofovir and emtricitabine to prevent HIV infection. J Antimicrob Chemother. 2011;66(2):240-50.

Araújo MAL, Bucher JSNF, Bello PY. Eficácia do aconselhamento para doenças sexualmente transmissíveis em unidades de referência da cidade de Fortaleza. 2004;16(1):317.

Araujo VG,Guillen FO, Pupulin ART,Amadei JL. Pessoas vivendo com HIV/Aids: influência das crenças na qualidade de vida e adesão ao tratamento. VI Mostra Interna de Trabalhos de Iniciação Científica. 2012; p 1-12.

Ayres JRCM et al. O conceito de vulnerabilidade e as práticas de saúde: novas perspectivas e desafios. In: Czeresnia D, Freitas CM e organizadores. Promoção da saúde: conceitos, reflexões, tendências. 2. ed. Rio de Janeiro: Ed Fiocruz; 2009. p 121-143.

Ayres JRCM, Paiva V, França I, Gravato N, Lacerda R, Della Negra M et al. Vulnerability human rights, and comprehensive health care needs of young people living with HIV/Aids. Am J Public Health. 2006;96(6):1001-6.

Ayres JRCM. Entrevista com José Ricardo Ayres. [entrevista a Marcelo Eduardo Pfeiffer Castellanos]. Saúde e Soc. 2018;27(1):51-60.

Ayres JRCM. Práticas educativas e prevenção de HIV/Aids: lições aprendidas e desafios atuais. Interface - Comun Saúde, Educ. 2002;6(11):11-24.

Barbosa BJP, Silva AP, Mota TJ, Nichiata LYI. Análise do conteúdo central dos aplicativos sobre HIV para smartphones. 2019;11(1):13-20.

Barbosa RM. Sexo e vida - panorama da saúde reprodutiva no Brasil. Campinas; Um olhar de gênero sobre epidemia de Aids 2003.; p. 339-89.

Barré-Sinoussi F, Chermann JC, Rey F, Nugeyre MT, Chamaret S, Gruest J et al. Isolation of a T-lymphotropic retrovirus from a patient at risk for acquired immune deficiency syndrome (Aids). Rev Investig Clin. 1983;56(2):126-9.

Bertolozzi MR, Nichiata LYI, Takahashi RF, Ciosak SI, Hino P, Val LF et al. Os conceitos de vulnerabilidade e adesão na Saúde Coletiva. Rev Esc Enferm USP. 2009;43(N. esp):132630 .

Bertolozzi MR. A adesão ao programa de controle da tuberculose no Distrito Sanitário de Butantã-SP [tese]. São Paulo: Faculdade de Saúde Pública, Universidade de São Paulo; 1998. 
Beymer MR, Kofron RM, Chi-Hong T, Bolan RK, Flynn RP, Sayles JM et al. Results from the post-exposure prophylaxis pilot program (P-QUAD) demonstration project in Los Angeles County. Int J STD Aids. 2018;29(6):557-62.

Beymer MR, Weiss RE, Bolan RK, Kofron RM, Flynn RP, Pieribone DL et al. Differentiating nonoccupational postexposure prophylaxis seroconverters and nonseroconverters in a community-based clinic in Los Angeles, California. Open Forum Infect Dis. 2017;4(2):1-10.

Bogoch II, Scully EP, Zachary KC, Yawetz S, Mayer KH, Bell CM et al. Patient attrition between the emergency department and clinic among individuals presenting for HIV nonoccupational postexposure prophylaxis. Clin Infect Dis. 2014;58(11):1618-24.

Brasil. Ministério da Saúde, Secretaria de Vigilância em Saúde, Departamento de Vigilância, Prevenção e Controle das IST, do HIV/Aids e das Hepatites Virais (DIAHV). Boletim Epidemiológico HIV e Aids. Brasília; 2019.

Brasil. Ministério da Saúde, Secretaria de Vigilância em Saúde. Boletim Epidemiológico HIV/Aids. Brasília; 2018a.

Brasil. Ministério da Saúde, Secretaria de Vigilância em Saúde, Departamento de Vigilância, Prevenção e Controle das Infecções Sexualmente Transmissíveis, do HIV/Aids e das Hepatites Virais. Protocolo clínico e diretrizes terapêuticas para profilaxia pré-exposição (PREP) de risco à infecção pelo HIV. Brasília; 2018b.

Brasil. Ministério da Saúde, Secretaria de Vigilância em Saúde, Departamento de Vigilância, Prevenção e Controle das Infecções Sexualmente Transmissíveis, do HIV/Aids e das Hepatites Virais. Protocolo clínico e diretrizes terapêuticas para profilaxia pós-exposição (PEP) de risco à infecção pelo HIV, IST e Hepatites Virais. Brasília; 2018c.

Brasil. Ministério da Saúde, Secretaria de Vigilância em Saúde, Departamento de Vigilância, Prevenção e Controle das Infecções Sexualmente Transmissíveis, do HIV/Aids e das Hepatites Virais. Protocolo clínico e diretrizes terapêuticas para manejo da infecção pelo HIV em adultos. Brasília; 2018d.

Brasil. Ministério da Saúde, Secretaria de Vigilância em Saúde, Departamento de Vigilância, Prevenção e Controle das Infecções Sexualmente Transmissíveis, do HIV/Aids e das Hepatites Virais. Cuidado integral às pessoas que vivem com HIV pela Atenção Básica: manual para a equipe multiprofissional. Brasília; 2017a.

Brasil. Ministério da Saúde, Secretaria de Vigilância em Saúde, Departamento de Vigilância, Prevenção e Controle das Infecções Sexualmente Transmissíveis, do HIV/Aids e das Hepatites Virais. Diretrizes para organização do CTA no âmbito da prevenção combinada e nas redes de atenção à saúde; 2017b.

Brasil. Ministério da Saúde, Secretaria de Vigilância em Saúde, Departamento de Vigilância, Prevenção e Controle das Infecções Sexualmente Transmissíveis, do HIV/Aids e das Hepatites Virais. Folder explicativo sobre o conceito e formas da prevenção combinada. Brasília; 2017c. Disponível em file://C:/Users/ens.USREE/Desktop/essencial_sobre_prevencao_combinada_-_folder.pdf. 
Brasil. Ministério da Saúde, Secretaria de Vigilância em Saúde, Departamento de Vigilância, Prevenção e Controle das Infecções Sexualmente Transmissíveis, do HIV/Aids e das Hepatites Virais. Prevenção combinada do HIV. Brasília; 2017d.

Brasil. Ministério da Saúde, Secretaria de Vigilância em Saúde, Departamento de DST, Aids e Hepatites Virais. Pesquisas de conhecimentos, atitudes e práticas na população brasileira. Brasília; 2016.

Brasil. Ministério da Saúde, Secretaria de Vigilância em Saúde, Departamento de Vigilância Epidemiológica. A, B, C, D, E de Hepatites para comunicantes. Brasília; 2005.

Cardo DM, Culver DH, Ciesielski CA, Srivastava PU, Marcus R, Abiteboul D et al. A casecontrol study of HIV seroconversion in health care workers after percutaneous exposure. $\mathrm{N}$ Engl J Med. 1997;337(21):1485-90.

Carneiro MBG, Elias DBD. HIV post-exposure prophylaxis in a hospital of infectious diseases in Fortaleza, CE. Rev Bras Análises Clínicas. 2018;50(1):65-70.

Center for Infectious Diseases (CDC). Updated guidelines for antiretroviral postexposure prophylaxis after sexual, injection drug use, or other nonoccupational exposure to HIVUnited, 2016. Atlanta: CDC; 2016.

Centers for Disease Control. First 500,000 Aids cases - United States, 1995 [Internet].1995 [cited 2019 Nov 15];44(46):849-853. Available from: https://www.cdc.gov/mmwr/preview/mmwrhtml/00039622.htm.

Chunqing L, Li L, Zunyou W, Sheng W, Manhong J. Occupational exposure to HIV among health care providers: a qualitative study in Yunnan, China. Journal of the International Association of Physicians in Aids Care. 2008;7(1):35-41.

Conselho Regional de Enfermagem. Parecer Coren-SP 033/2019. Ementa: Prescrição de medicamentos por abordagem sindrômica para prevenção pré-exposição (PrEP), prevenção pós-exposição (PEP) e infecções sexualmente transmissíveis (ISTs) pelo enfermeiro. São Paulo; 2019. Disponível em: file:///C:/Users/ens.USREE/Desktop/102057-33\%20(1).pdf.

Deienno MCV, Farias N, Chencinscki J, Simões RN. Perfil dos usuários do serviço de aconselhamento no Serviço de Assistência Especializada em DST/Aids Campos Elíseos, Município de São Paulo, Brasil. 2010;7(74):13-22.

Edmundo K, Souza CM, Carvalho M, Paiva V. Vulnerabilidade ao HIV em favela do Rio de Janeiro: impacto de uma intervenção territorial. Rev Saúde Pública. 2007;41(suppl 2):12734.

Farias N, Tancredi MV. Características dos usuários e fatores associados à soropositividade para o HIV em usuários de Centros de Testagem e Aconselhamento (CTA) no estado de São Paulo, 2000 a 2007. 2008;5(60):9-18.

Ferraz DAS. Experiência de mulheres usuárias de profilaxia pós-exposição ao HIV (PEP sexual): cenários pessoais e programáticos para a prevenção da Aids [tese]. São Paulo: Faculdade de Medicina, Universidade de São Paulo; 2018.

Fletcher JB, Rusow JA, Hung L, Landovitz RJ, Reback CJ. High-risk sexual behavior is 
associated with postexposure prophylaxis nonadherence among men who have sex with men enrolled in a combination prevention intervention. J Sex Transm Dis. 2013;(2013):1-7.

Ford N, Irvine C, Shubber Z, Baggaley R, Beanland R, Vitoria M et al. Adherence to HIV postexposure prophylaxis: A systematic review and meta-analysis. Aids. 2014;28(18):27217.

Ford N, Mayer KH, Barlow L, Bagyinszky F, Calmy A, Chakroun M et al. World health organization guidelines on postexposure prophylaxis for HIV: Recommendations for a public health approach. Clin Infect Dis. 2015;60 Sup13:S161-4.

Foster R, McAllister J, Read TR, Pierce AB, Richardson R, McNulty A et al. Single-tablet emtricitabine-rilpivirine-tenofovir as HIV postexposure prophylaxis in men who have sex with men. Clin Infect Dis. 2015;61(8):1336-41.

Gallo RC, Salahuddin SZ, Popovic M, Shearer GM, Kaplan M, Haynes BF et al. Frequent detection and isolation of cytopathic retroviruses (HTLV-III) from patients with Aids and at risk for Aids. Science 1984; 4;224(4648):500-3.

Geary RS, Gómez-Olivé FX, Kahn K, Tollman S, Norris SA. Barriers to and facilitators of the provision of a youth-friendly health services programme in rural South Africa. BMC Health Serv Res. 2014;14(1):1-8.

Grangeiro A, Nascimento MMP, Zucchi EM, Ferraz D, Escuder MM, Arruda E et al. Nonoccupational post-exposure prophylaxis for HIV after sexual intercourse among women in Brazil: Risk profiles and predictors of loss to follow-up. Med. 2019;98(39):1-9.

Hinkin CH, Barclay TR, Castellon SA, Levine AJ, Durvasula RS, Marion SD et al. Drug use and medication adherence among HIV-1 infected individuals. Aids Behav. 2007;11(2):18594.

Hugo JM, Stall RD, Rebe K, Egan JE, De Swardt G, Struthers H et al. Anti-retroviral therapybased HIV prevention among a sample of men who have sex with men in Cape Town, South Africa: Use of post-exposure prophylaxis and knowledge on pre-exposure prophylaxis. Aids Behav. 2016;20 Supl3:S357-64.

Inciarte A, Leal L, González E, León A, Lucero C, Mallolas J et al. Tenofovir disoproxil fumarate/emtricitabine plus ritonavir-boosted lopinavir or cobicistat-boosted elvitegravir as a single-tablet regimen for HIV post-exposure prophylaxis. J Antimicrob Chemother. 2017;72(10):2857-61.

Irvine C, Egan KJ, Shubber Z, Van Rompay KKA, Beanland RL, Ford N. Efficacy of HIV postexposure prophylaxis: Systematic review and meta-analysis of nonhuman primate studies. Clin Infect Dis. 2015;60 Supl3:S165-9.

Izulla P, McKinnon LR, Munyao J, Karanja S, Koima W, Parmeres J et al. HIV postexposure prophylaxis in an urban population of female sex workers in Nairobi, Kenya. J Acquir Immune Defic Syndr. 2013;62(2):220-5.

Joint United Nations Program on HIV/Aids (UNAIDS). Programa Conjunto das Nações Unidas. Estatísticas [internet]. Brasília; 2020a [acesso em 08 jan 2020]. Disponível em: https://unaids.org.br/estatisticas/. 
Joint United Nations Program on HIV/Aids (UNAIDS). Programa Conjunto das Nações Unidas. People living with HIV receiving ART. [internet]. Brasília; 2020b [acesso em 08 jan 2020]. Disponível em: http://aidsinfo.unaids.org/.

Kahn JO, Martin JN, Roland ME, Bamberger JD, Chesney M, Chambers D et al. Feasibility of postexposure prophylaxis (PEP) against human immunodeficiency virus infection after sexual or injection drug use exposure: The San Francisco PEP Study. J Infect Dis. 2001; $183: 707-14$.

Kerr L, Kendall C, Guimarães MDC, Mota RS, Veras MA, Dourado I et al. HIV prevalence among men who have sex with men in Brazil: Results of the 2nd national survey using respondent-driven sampling. Med (United States). 2018;97 Sup1:S9-15.

Kerr LR, Mota RS, Kendall C, Pinho AA, Mello MB, Guimarães MD et al. HIV among MSM in a large middle-income country. Aids. 2013;27(3):427-35.

Landovitz RJ, Fletcher JB, Inzhakova G, Lake JE, Shoptaw S, Reback CJ. A novel combination HIV prevention strategy: Post-exposure prophylaxis with contingency management for substance abuse treatment among methamphetamine-using men who have sex with men. Aids Patient Care STDS. 2012;26(6):320-8.

Landovitz, RJ, Fletcher JB, Shoptaw S, Reback CJ. Contingency management facilitates the use of postexposure prophylaxis among stimulant-using men who have sex with men. 2014;2(1):1-9.

Leal L, León A, Torres B, Inciarte A, Lucero C, Mallolas J et al. A randomized clinical trial comparing ritonavir-boosted lopinavir versus maraviroc each with tenofovir plus emtricitabine for post-exposure prophylaxis for HIV infection. J Antimicrob Chemother. 2016;71(7):1982-6.

Lima ICV, Galvão MTG, Pedrosa SC, Cunha GH, Costa AKB. Use of the WhatsApp application in health follow-up of people with HIV: a thematic analysis. Esc Anna Nery. 2018;22(3):1-6.

Liza PH. Profilaxia pós-exposição sexual para HIV: uma análise retrospectiva sobre a adesão e o seguimento das pessoas assistidas [dissertação]. Belo Horizonte (BH): Escola de Enfermagem da Universidade Federal de Minas Gerais, Universidade Federal de Minas Gerais; 2019.

Lopes F, Buchalla CM, Ayres JRCM. Mulheres negras e não negras e vulnerabilidade ao HIV/Aids no estado de São Paulo, Brasil. Rev Saúde Pública. 2007;41 Sup12:S39-46.

Malinverni S, Libois A, Gennotte AF, Morté C La, Mols P. Prescription of non-occupational post-exposure HIV prophylaxis by emergency physicians: An analysis on accuracy of prescription and compliance. PLoS One. 2016;11(4):1-11.

Malinverni S, Libois A, Schuster M, De Wit S, Mols P, Gennotte AF. Adherence to HIV post-exposure prophylaxis: A multivariate regression analysis of a 5 years prospective cohort. J Infect. 2018;76(1):78-85.

Mann JM, Tarantola DJM Netter TW. A Aids no mundo. Coleção histórica social da Aids. 
ABIA: Rio de Janeiro; 1993.

Mann JM. Aids: The second decade: A global perspective. 1992;165(2):245-50.

Mayer KH, Jones D, Oldenburg C, Jain S, Gelman M, Zaslow S et al. Excellent HIV postexposure prophylaxis regimen completion with single tablet daily elvitegravir/cobicistat/tenofovir disoproxil fumarate/emtricitabine compared to more frequent dosing regimens. J Acquir Immune Defic Syndr. 2017;75(5):535-9.

Mayer KH, Mimiaga MJ, Gelman M, Grasso C. Raltegravir, tenofovir DF, and emtricitabine for postexposure prophylaxis to prevent the sexual transmission of HIV: Safety, tolerability, and adherence. J Acquir Immune Defic Syndr. 2012;59(4):354-9.

McAllister J, Read P, McNulty A, Tong WWY, Ingersoll A, Carr A et al. Raltegraviremtricitabine-tenofovir as HIV nonoccupational post-exposure prophylaxis in men who have sex with men: Safety, tolerability and adherence. HIV Med. 2014;15(1):13-22.

McAllister JW, Towns JM, McNulty A, Pierce AB, Foster R, Richardson R et al. Dolutegravir with tenofovir disoproxil fumarate-emtricitabine as HIV postexposure prophylaxis in gay and bisexual men. Aids. 2017;31(9):1291-5.

Mendes TA, Souza SJP, Stigar R, Burci LM. Conhecimento de adultos jovens sobre a prevenção, transmissão e tratamento do HIV/Aids. 2017;17(supl 1):20-8.

Milinkovic A, Benn P, Arenas-Pinto A, Brima N, Copas A, Clarke A et al. Randomized controlled trial of the tolerability and completion of maraviroc compared with Kaletra ${ }^{\circledR}$ in combination with Truvada ${ }^{\circledR}$ for HIV post-exposure prophylaxis (MiPEP Trial). J Antimicrob Chemother. 2017;72(6):1760-8.

Nakano AK. Desigualdades habitacionais no "repovoamento" do centro expandido do município de São Paulo. Cad Metrópole. 2018;20(41):53-74.

Nichiata LYI, Bertolozzi MR, Takahashi RF, Fracolli LA. A utilização do conceito "vulnerabilidade" pela enfermagem. Rev Lat Am Enfermagem. 2008;16(5).

Oldenburg C, Perez-Brumer A, Hatzenbuehler M, Douglas Krakower, David Novak, Matthew Mimiaga et al. Structural stigma affects access to pre- and post-exposure prophylaxis and HIV risk among men who have sex with men (MSM) in the United States. Aids research and human retroviruses. 2014;30(Suppl 1):22-3.

Organização Pan-Americana da Saúde (Opas). Mais de 2,1 milhões de pessoas vivem com HIV na América Latina e Caribe [internet] 2018 [acesso em 08 jan 2020]. Disponível em: https://nacoesunidas.org/mais-de-21-milhoes-de-pessoas-vivem-com-hiv-na-america-latinae-caribe/.

Otten RA, Smith DK, Adams DR, Pullium JK, Jackson E, Kim CN et al. Efficacy of postexposure prophylaxis after intravaginal exposure of pig-tailed macaques to a humanderived retrovirus (human immunodeficiency virus type 2). J Virol. 2000;74(20):9771-5.

Oz N, Alon D, Stein GY, Turner D. Adherence and characteristics of HIV post-exposure prophylaxis for a population in Tel Aviv of men who have sex with men. Isr Med Assoc J. 2017;19(4):257-61. 
Paiva V, Peres C, Blessa C. Jovens e adolescentes em tempos de Aids: reflexões sobre uma década de trabalho de prevenção. Rev Psicol USP. 2002;13(1):55-78.

Pando MA, Balán IC, Marone R, Dolezal C, Leu CS, Squiquera L et al. HIV and other sexually transmitted infections among men who have sex with men recruited by RDS in Buenos Aires, Argentina: High HIV and HPV infection. PLoS One. 2012;7(6):1-7.

Parker R et al. Estigma, discriminação e Aids. Associação Brasileira Interdisciplinar de Aids - ABIA. Rio de Janeiro; 2001.

Pasternak S, Bógus LMM. Habitação de aluguel no Brasil e em São Paulo. Cad CRH. 2014;27(71):235-54.

Pires PV. E fazer "tudo direitinho": cuidados e enfrentamentos nas políticas de saúde em resposta ao HIV/Aids em mulheres [dissertação]. Porto Alegre: Universidade Federal do Rio Grande do Sul; 2016.

Rasoolinejad M, Sadat BN, Najafi Z, Baesi K, Heidari H, Seyedalinaghi S. Epidemiological and clinical information of people at risk for HIV referred to the voluntary counseling and testing center, Tehran, Iran, 2013-2014. J Int Transl Med. 2018;6(4):176-80.

Remor E, Milner-Moskovics J, Preussler G. Adaptação brasileira do "Cuestionario para la Evaluación de la Adhesión al Tratamiento Antiretroviral". Rev Saúde Pública. 2007; 41(5):685-94.

Ribeiro MCSA, Barata RB, Almeida MF, Silva ZP. Perfil sociodemográfico e padrão de utilização de serviços de saúde para usuários e não usuários do SUS - PNAD 2003. Cienc e Saúde Coletiva. 2006;11(4):1011-22.

Roland ME, Neilands TB, Krone MR, Katz MH, Franses K, Grant RM et al. Seroconversion following nonoccupational postexposure prophylaxis against HIV. Clin Infect Dis. 2005;41(10):1507-13.

Russell CK, Bunting SM, Graney M, Hartig MT, Kisner P, Brown B. Factors that influence the medication decision making of persons with HIV/Aids: A taxonomic exploration. J Assoc Nurses Aids Care. 2003;14(4):46-60.

Sánchez AIM, Bertolozzi MR. Pode o conceito de vulnerabilidade apoiar a construção do conhecimento em Saúde Coletiva? Cienc e Saúde Coletiva. 2007;12(2):319-24.

Santos AO, Paiva V. Vulnerabilidade ao HIV: turismo e uso de álcool e outras drogas. Rev Saúde Pública. 2007;41(suppl 2):80-6.

Santos NJS, Barbosa RM, Pinho AA, Villela WV, Aidar T, Filipe EMV. Contextos de vulnerabilidade para o HIV entre mulheres brasileiras. Cad Saúde Pública. 2009;25 Supl 2:S321-33.

Santos WJ, Drumond EF, Gomes AS, Corrêa CM, Freitas MIF. Barreiras e aspectos facilitadores da adesão à terapia antirretroviral em Belo Horizonte-MG. Rev Bras Enferm. 2011;64(6):1028-37. 
São Paulo. Prefeitura de São Paulo, Programa Municipal de DST/Aids. Linhas de cuidado de IST/Aids. São Paulo; 2018.

São Paulo. Programa Municipal DST, HIV e Aids no município de São Paulo 2014: profilaxia pós-exposição sexual. [acesso em 03 jan 2020]. Disponível em: http://www3.crt.saude.sp.gov.br/profilaxia/hotsite/index.php?pags=buscar-servico.

São Paulo. Secretaria da Saúde, Coordenação de Vigilância em Saúde. Manual prático de vigilância epidemiológica de DST/Aids. São Paulo; SMS; 2012.

São Paulo. Secretaria Estadual de São Paulo, Secretaria Municipal de São Paulo. HIV e Aids no município de São Paulo 2014: resumo da epidemia [Internet]. São Paulo; 2015 [citado em 20 nov 2019]. 14 p. Disponível em: https://www.prefeitura.sp.gov.br/cidade/secretarias/upload/saude/base_lay_27-11.pdf.

São Paulo. Secretaria Municipal de São Paulo, Boletim Epidemiológico de HIV/Aids [Internet]. São Paulo; 2019 [citado em 22 nov 2019]. 58 p. Disponível em: https://www.prefeitura.sp.gov.br/cidade/secretarias/upload/boletim_epidemiologico_HIV_ Aids_SP_2019.pdf.

São Paulo. Secretaria Municipal de São Paulo, Coordenadoria de Controle de Doenças, Centro de Referência e Treinamento DST/Aids de São Paulo, Programa Estadual de DST/Aids de São Paulo. Diretrizes para implementação da rede de cuidados em IST/HIV/Aids - Manual de prevenção. São Paulo; 2017.

Schechter M, Do Lago RF, Mendelsohn AB, Moreira RI, Moulton LH, Harrison LH. Behavioral impact, acceptability, and HIV incidence among homosexual men with access to postexposure chemoprophylaxis for HIV. J Acquir Immune Defic Syndr. 2004;35(5):51925.

Schechter M. Profilaxia pré e pós-exposição: o uso de drogas antirretrovirais para a prevenção da transmissão sexual da infecção pelo HIV. Brazilian J Infect Dis. 2016;2(4):1127.

Secretaria de Saúde do município de São Paulo. Disponível em: https://www.prefeitura.sp.gov.br/cidade/secretarias/saude/organizacao/coordenadorias_saud e/index.php?p=6541.

Silva ALCN, Waidman MAP, Marcon SS. [Adhesion and non-adhesion to anti-retroviral therapy: the two faces of a same experience]. Rev Bras Enferm. 2009;62(2):213-20.

Silva CL. Construção de uma escala de avaliação de adesão à profilaxia pós-exposição sexual ao HIV [tese]. São Paulo: Escola de Enfermagem, Universidade de São Paulo; 2018.

Sperling RS, Shapiro DE, Coombs RW, Todd JA, Herman SA, Mcsherry GD et al. Maternal viral load, zidovudine treatment, and the risk of transmission of human immunodeficiency virus type 1 from mother to infant. N Engl J Med. 1996;335(22):1621-9.

Spira AI, Marx PA, Patterson BK, Mahoney J, Koup A, Wolinsky SM et al. Cellular targets of infection and route of viral dissemination after an intravaginal inoculation of simian immunodeficiency virus into rhesus macaques 1996;183(12):215-25. 
Sultan B, Benn P, Waters L. Current perspectives in HIV post-exposure prophylaxis. HIV/Aids - Res Palliat Care. 2014;6:147-58.

Thomas R, Galanakis C, Vézina S, Longpré D, Boissonnault M, Huchet E et al. Adherence to post-exposure prophylaxis (PEP) and incidence of HIV seroconversion in a major North American cohort. PLoS One. 2015;10(11):1-10.

Trapé CA. Operacionalização do conceito de classes sociais em epidemiologia crítica: uma proposta de aproximação a partir da categoria reprodução social [tese]. São Paulo: Escola de Enfermagem, Universidade de São Paulo; 2011.

Tsai C-C, Emau P, Follis KE, Beck TW, Benveniste RE, Bischofberger N et al. Effectiveness of postinoculation (R)-9-(2-phosphonylmethoxypropyl)adenine treatment for prevention of persistent simian immunodeficiency virus SIVmne infection depends critically on timing of initiation and duration of treatment. J Virol. 1998;72(5):4265-73.

Valin N, Fonquernie L, Daguenel A, Campa P, Anthony T, Guiguet M et al. Evaluation of tolerability with the co-formulation elvitegravir, cobicistat, emtricitabine, and tenofovir disoproxil fumarate for post-HIV exposure prophylaxis. BMC Infect Dis. 2016;16(718):1-5.

Wade NA, Birkhead GS, Warren BL, Charbonneau TT, French PT, Wang L et al. Abbreviated regimens of zidovudine prophylaxis and perinatal transmission of the human immunodeficiency virus. The New England Journal of Medicine. 1998;339(20):1409-14.

Wainberg MA, Kuan-Teh J. 25 years of HIV-1 research - progress and perspectives. BMC Medicine. 2008;6(1):1-7.

World Health Organization. HIV drug resistance report 2019. Geneva; 2019.

Zoni AC, González MA, Sjögren HW. Syphilis in the most at-risk populations in Latin America and the Caribbean: A systematic review. Int J Infect Dis. 2013;17(2):1-9.

Zou H, Fairley CK, Guy R, Bilardi J, Bradshaw CS, Garland SM et al. Automated, computer generated reminders and increased detection of gonorrhoea, chlamydia and syphilis in men who have sex with men. PLoS One. 2013;8(4):2-9.

Zucchi EM, Grangeiro A, Ferraz D, Pinheiro TF, Alencar T, Ferguson L et al. Da evidência à ação: desafios do Sistema Único de Saúde para ofertar a profilaxia pré-exposição sexual (PrEP) ao HIV às pessoas em maior vulnerabilidade. Cad Saúde Pública. 2018;34(7):1-16. 


\section{APÊNDICE 1}

Apêndice 1 - Questionário sobre as características sociodemográficas, formas de viver, formas de trabalhar, processo de saúde e atendimento do serviço de saúde.

\begin{tabular}{|c|c|c|}
\hline \multicolumn{3}{|l|}{ 1. Características sociodemográficas } \\
\hline \multicolumn{3}{|l|}{ 1. Iniciais do nome: } \\
\hline \multicolumn{3}{|l|}{ 2. Nome social: } \\
\hline \multirow{2}{*}{\multicolumn{3}{|c|}{$\begin{array}{l}\text { 3. Data de nascimento } \\
\text { 4. País de nascimento }\end{array}$}} \\
\hline & & \\
\hline \multirow[t]{2}{*}{ 5. Sexo } & \multicolumn{2}{|c|}{ Masculino (1) Feminino (2) } \\
\hline & \multicolumn{2}{|c|}{ Sem registro/informação (66) } \\
\hline \multirow[t]{2}{*}{ 6. Travesti } & \multicolumn{2}{|c|}{$\operatorname{Sim}(1) \quad$ Não (0) } \\
\hline & \multicolumn{2}{|c|}{ Sem registro/informação (66) } \\
\hline \multirow[t]{4}{*}{ 7. Transgênero } & \multirow[t]{2}{*}{$\operatorname{Sim}(1)$} & Homem (1) \\
\hline & & Mulher (2) \\
\hline & \multicolumn{2}{|c|}{ Não $(0)$} \\
\hline & \multicolumn{2}{|c|}{ Sem registro/informação (66) } \\
\hline $\begin{array}{l}\text { 8. Quanto à sua orientação sexual - com } \\
\text { quem se relaciona }\end{array}$ & \multicolumn{2}{|c|}{$\begin{array}{l}\text { Apenas com homens (0), com homens e } \\
\text { mulheres (1), apenas com mulheres (2), } \\
\text { travesti (3), transgênero (4), não informado } \\
(55)\end{array}$} \\
\hline \multirow[t]{4}{*}{ 9. Gestante } & $\operatorname{Sim}(1)$ & $\begin{array}{l}\text { Idade gestacional em } \\
\text { meses ( ) }\end{array}$ \\
\hline & \multicolumn{2}{|l|}{ Não (0) } \\
\hline & \multicolumn{2}{|c|}{ Não se aplica (99) } \\
\hline & \multicolumn{2}{|c|}{ Sem registro/informação (66) } \\
\hline 10. Raça (autorreferida) & \multicolumn{2}{|c|}{$\begin{array}{l}\text { Branca (0), preta (1), amarela (2), parda (3), } \\
\text { indígena (4), ignorado (00), sem } \\
\text { registro/informação (66) }\end{array}$} \\
\hline 11. Com quem mora? & \multicolumn{2}{|c|}{$\begin{array}{l}\text { Com companheiro(a) (0), sozinho (1), com } \\
\text { outras pessoas (2), ignorado (00), sem } \\
\text { registro/informação (66) }\end{array}$} \\
\hline 12. Escolaridade & \multicolumn{2}{|c|}{$\begin{array}{l}\text { Não sabe ler/escrever (0), alfabetizado (1). } \\
\text { fund. incompleto (2), fund. completo (3), } \\
\text { médio incompleto (4), médio completo (5), } \\
\text { superior incompleto (6), superior completo } \\
\text { (7), sem registro/informação (66), outros } \\
\text { (77) qual? }\end{array}$} \\
\hline \multicolumn{3}{|l|}{ 13. Telefone para contato } \\
\hline \multicolumn{3}{|l|}{ 14. Município de residência } \\
\hline \multicolumn{3}{|l|}{ 2. Formas de viver } \\
\hline $\begin{array}{l}\text { 15. Quantas pessoas compartilham o } \\
\text { domicílio onde você mora? }\end{array}$ & \multicolumn{2}{|c|}{$\begin{array}{l}\text { Moro sozinho (0), duas pessoas (1), três } \\
\text { pessoas (2), mais de três pessoas (3). } \\
\text { Quantas? }\end{array}$} \\
\hline \multirow[t]{2}{*}{ 16. Quem é o chefe da família? } & \multicolumn{2}{|l|}{ Próprio (0) } \\
\hline & Outra pessoa (1) & Quem? \\
\hline
\end{tabular}




\begin{tabular}{|c|c|c|c|}
\hline 17. A sua renda, ou da sua família, é & Alimentação & \multicolumn{2}{|c|}{ Sim (1) Não (0) } \\
\hline & Lazer & \multicolumn{2}{|c|}{ Sim (1) Não (0) } \\
\hline & Escola & \multicolumn{2}{|c|}{ Sim (1) Não (0) } \\
\hline & Vestuário & \multicolumn{2}{|c|}{ Sim (1) Não (0) } \\
\hline & Saúde & \multicolumn{2}{|c|}{ Sim (1) Não (0) } \\
\hline & Transporte & \multicolumn{2}{|c|}{ Sim (1) Não (0) } \\
\hline & $\begin{array}{l}\text { Acesso } \\
\text { informação }\end{array}$ & & $\begin{array}{l}\text { Internet } \\
(1), \text { livros } \\
(2), \\
\text { revistas (3) }\end{array}$ \\
\hline & & \multicolumn{2}{|c|}{ Não (0) } \\
\hline 18. Você recebe algum benefício social? & $\operatorname{Sim}(1)$ & \multicolumn{2}{|c|}{ Qual? } \\
\hline & Não (0) & & \\
\hline $\begin{array}{l}\text { 19. Em relação à propriedade do seu } \\
\text { domić́lio: }\end{array}$ & \multicolumn{3}{|c|}{$\begin{array}{l}\text { Cedida (0), alugada (1), própria (2), } \\
\text { ocupação (3), não sabe (88), outros (77) }\end{array}$} \\
\hline 20. Você paga IPTU? & \multicolumn{3}{|c|}{$\begin{array}{l}\text { Sim (1), não (0), não, porque é isento (2), não } \\
\text { sabe (88) }\end{array}$} \\
\hline 21. Você tem alguma crença religiosa? & \multirow{2}{*}{\multicolumn{3}{|c|}{$\begin{array}{l}\text { Sim (1) Não (0) } \\
\text { Não (0), escola (1), igreja (2), bairro (3), } \\
\text { trabalho (4), trabalho voluntário (5), outro } \\
\text { tipo de agrupamento (6). Qual? }\end{array}$}} \\
\hline $\begin{array}{l}\text { 22. Você participa de algum grupo, } \\
\text { associação ou sindicato ligado a: (pode ter } \\
\text { mais de uma resposta) }\end{array}$ & & & \\
\hline \multicolumn{4}{|l|}{ 3. Formas de trabalhar } \\
\hline 23. No momento, você está trabalhando? & \multicolumn{3}{|c|}{$\begin{array}{l}\text { Sim (1), não (0), não, mas está procurando } \\
\text { emprego (2) }\end{array}$} \\
\hline \multicolumn{4}{|l|}{ 24. Qual a sua profissão? } \\
\hline \multicolumn{4}{|l|}{$\begin{array}{l}\text { 25. Se está trabalhando, qual a sua ocupação } \\
\text { no momento? }\end{array}$} \\
\hline 26. Você tem registro em carteira? & \multicolumn{3}{|l|}{ Sim (1) Não (0) } \\
\hline $\begin{array}{l}\text { 27. Caso seja o chefe da família, fez algum } \\
\text { curso preparatório para a ocupação que tem } \\
\text { no momento? }\end{array}$ & \multicolumn{3}{|c|}{ Sim (1), Não (0), não se aplica (99) } \\
\hline \multirow{5}{*}{$\begin{array}{l}\text { 28. Você recebe algum benefício referente } \\
\text { ao seu trabalho? }\end{array}$} & Vale-transporte & \multicolumn{2}{|c|}{ Sim (1) Não (0) } \\
\hline & Cesta básica & \multicolumn{2}{|c|}{ Sim (1) Não (0) } \\
\hline & Plano de saúde & \multicolumn{2}{|c|}{ Sim (1) Não (0) } \\
\hline & Vale-refeição & \multicolumn{2}{|c|}{ Sim (1) Não (0) } \\
\hline & Outros & \multicolumn{2}{|c|}{ Sim (1) Qual? } \\
\hline \multicolumn{4}{|l|}{ 4. Processo de saúde } \\
\hline $\begin{array}{l}\text { 29. Se apresentou IST nos últimos anos, } \\
\text { onde tratou? }\end{array}$ & \multicolumn{3}{|c|}{$\begin{array}{l}\text { Serviço de saúde (0), farmácia }(1) \text {, } \\
\text { automedicação (2), não lembra (3), não } \\
\text { tratou (4), não informado (5), sem } \\
\text { registro/informação (66), não se aplica (99) }\end{array}$} \\
\hline 30. Qual IST? & \multicolumn{3}{|c|}{$\begin{array}{l}\text { ( ), não se aplica (99), sem } \\
\text { registro/informação (66) }\end{array}$} \\
\hline
\end{tabular}




\begin{tabular}{|l|l|l|}
\hline 31. Já teve sífilis alguma vez na vida? & Sim (1) & Tratou? Sim (1) Não (0) \\
\cline { 2 - 3 } & $\begin{array}{l}\text { Não (0), sem } \\
\text { registro/ } \\
\text { informação (66) }\end{array}$ & \\
\hline 32. Quando tratou a sífilis? & \multicolumn{1}{|c|}{ / } & \\
\hline \multirow{3}{*}{ 33. Faz uso de drogas? } & $\begin{array}{l}\text { Não se aplica (99), sem registro/informação } \\
\text { (66) }\end{array}$ \\
\hline $\begin{array}{l}\text { 34. Quais as drogas que o usuário do serviço } \\
\text { de saúde usa ou usou durante a vida }\end{array}$ & $\begin{array}{l}\text { Sim (1), não (0), já usou, mas não usa mais } \\
\text { (2), usa de vez em quando (3), usa } \\
\text { frequentemente (4), sem registro/informação } \\
\text { (66) }\end{array}$ \\
\hline $\begin{array}{l}\text { Álcool (0), crack (1), cocaína (2), injetável } \\
\text { 3), ecstasy (4), anfetaminas (5), cocaína } \\
\text { aspirada (6), maconha (7), outras (77), não se } \\
\text { aplica (99), sem registro/informação (66) }\end{array}$ \\
\hline antes do teste de hoje?
\end{tabular}




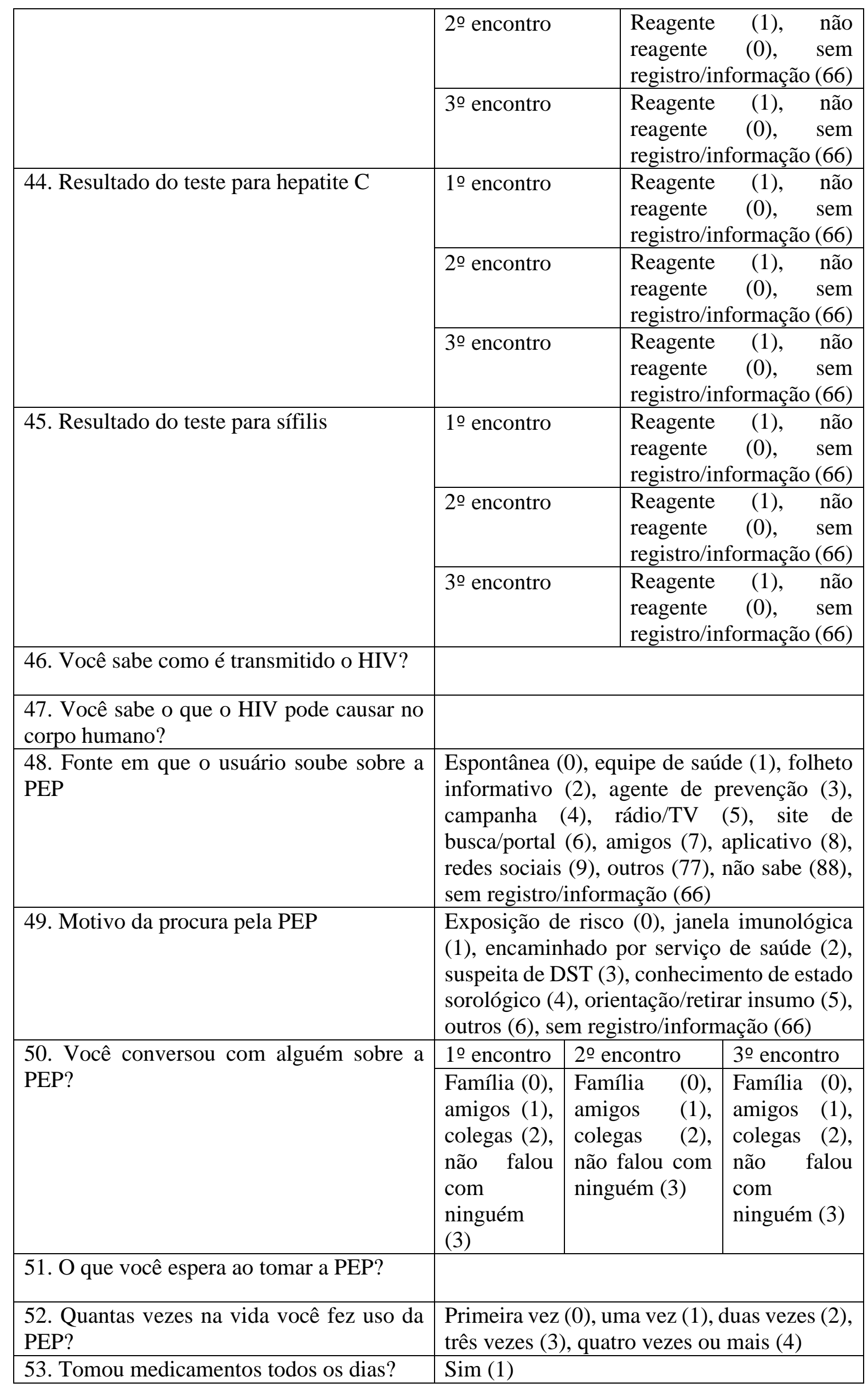




\begin{tabular}{|c|c|c|}
\hline & Não (0) & $\begin{array}{l}\text { Por quê? } \\
\text { Esqueceu (0), não quis } \\
\text { tomar (1), comprimido } \\
\text { muito grande (2), efeitos } \\
\text { colaterais (3), outros } \\
\text { (77). Qual? }\end{array}$ \\
\hline 54. Você teve algum efeito colateral? & \multirow{2}{*}{\multicolumn{2}{|c|}{$\begin{array}{l}\text { Náuseas (0), vômitos (1), diarreia (2), dor } \\
\text { abdominal (3), olhos amarelados (4), } \\
\text { sonolência (5), outros (6) } \\
\text { Um dia (0), dois dias (1), três dias (2), quatro } \\
\text { dias (3), cinco dias (4), mais de cinco dias } \\
\text { (5). Quantos? }\end{array}$}} \\
\hline $\begin{array}{l}\text { 55. Quantos dias ficou sem tomar os } \\
\text { medicamentos? }\end{array}$ & & \\
\hline $\begin{array}{l}\text { 56. O que o(a) motiva a tomar os } \\
\text { medicamentos? }\end{array}$ & \multicolumn{2}{|c|}{$\begin{array}{l}\text { Projetos para o futuro (0), educação dos } \\
\text { filhos (1), trabalho (2), não contrair o HIV } \\
\text { (3), outros (77). Qual? }\end{array}$} \\
\hline \multirow{2}{*}{$\begin{array}{l}\text { 57. Você já teve vontade de desistir de } \\
\text { tomar os medicamentos? }\end{array}$} & $\operatorname{Sim}(1)$ & Por quê? \\
\hline & Não (0) & Por quê? \\
\hline \multirow[t]{2}{*}{$\begin{array}{l}\text { 58. Quais foram as facilidades e } \\
\text { dificuldades para tomar o medicamento? }\end{array}$} & Dificuldades & $\begin{array}{l}\text { Preconceito/vergonha } \\
(0) \text {, medo (1), falta } \\
\text { apoio de amigos e } \\
\text { família (2), outros (77). } \\
\text { Qual? }\end{array}$ \\
\hline & Facilidades & $\begin{array}{lr}\text { Acesso } & \text { aos } \\
\text { medicamentos } & (1), \\
\text { acesso ao serviço } & \text { de } \\
\text { saúde (2) } & \end{array}$ \\
\hline \multirow[t]{4}{*}{$\begin{array}{l}\text { 59. Você teve alguma exposição ao HIV nos } \\
\text { últimos } 30 \text { dias? }\end{array}$} & $\begin{array}{l}\text { 2o encontro } \\
\operatorname{Sim}(1)\end{array}$ & 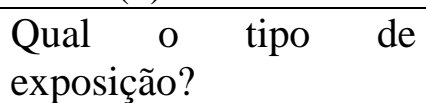 \\
\hline & Não (0) & \\
\hline & $\begin{array}{l}\text { 3o encontro } \\
\text { Sim (1) }\end{array}$ & $\begin{array}{l}\text { Qual o tipo } \mathrm{de} \\
\text { exposição? }\end{array}$ \\
\hline & Não (0) & \\
\hline \multicolumn{3}{|l|}{$\begin{array}{l}\text { 60. Qual o tipo de exposição que você teve } \\
\text { para a qual foi indicada a PEP? }\end{array}$} \\
\hline \multicolumn{3}{|l|}{$\begin{array}{l}\text { 61. Você usou preservativo na exposição } \\
\text { para a qual foi indicada a PEP? }\end{array}$} \\
\hline \multicolumn{3}{|l|}{ 4.1. Perguntas realizadas por telefone } \\
\hline \multirow{2}{*}{$\begin{array}{l}\text { 62. Você tomou os medicamentos todos os } \\
\text { dias? }\end{array}$} & \multicolumn{2}{|l|}{$\operatorname{Sim}(1)$} \\
\hline & \multicolumn{2}{|l|}{ Não (0) } \\
\hline \multicolumn{3}{|l|}{$\begin{array}{l}\text { 62. Quantos dias você deixou de tomar o } \\
\text { medicamento? }\end{array}$} \\
\hline $\begin{array}{l}\text { 63. Por quais motivos você não voltou ao } \\
\text { serviço de saúde? }\end{array}$ & & \\
\hline
\end{tabular}




\begin{tabular}{|c|c|c|}
\hline \multirow[t]{2}{*}{$\begin{array}{l}\text { 64. Você iniciou a profilaxia pós-exposição } \\
\text { em outro serviço de saúde? }\end{array}$} & $\operatorname{Sim}(1)$ & $\begin{array}{llll}\text { SAE (0), } & \text { CRT } & (1), \\
\text { AMA (2), } & \text { PS } & (3), \\
\text { hospital (4), } & \text { CR } & (5), \\
\text { CTA (6), UPA (7) }\end{array}$ \\
\hline & \multicolumn{2}{|l|}{ Não (0) } \\
\hline \multirow[t]{3}{*}{$\begin{array}{l}\text { 65. Em média, quanto tempo você } \\
\text { permaneceu no serviço de saúde durante o } \\
\text { processo? }\end{array}$} & 1 ㅇ encontro & $\begin{array}{l}<30 \min (0), 30 \min -1 \mathrm{~h} \\
(1),+ \text { que } 1 \mathrm{~h} \text { até } 2 \mathrm{~h}(2), \\
+ \text { do que } 2 \mathrm{~h} \text {. Quanto } \\
\text { tempo? ( ) }\end{array}$ \\
\hline & 2 ㅇ encontro & $\begin{array}{l}<30 \min (0), 30 \min -1 \mathrm{~h} \\
(1),+ \text { que } 1 \mathrm{~h} \text { até } 2 \mathrm{~h}(2), \\
+ \text { do que } 2 \mathrm{~h} \text {. Quanto } \\
\text { tempo? ( ) }\end{array}$ \\
\hline & 3 o encontro & $\begin{array}{l}<30 \min (0), 30 \min -1 \mathrm{~h} \\
(1),+ \text { que } 1 \mathrm{~h} \text { até } 2 \mathrm{~h}(2), \\
+ \text { do que } 2 \mathrm{~h} \text {. Quanto } \\
\text { tempo? }\end{array}$ \\
\hline \multirow[t]{3}{*}{$\begin{array}{l}\text { 66. O que mais demorou durante o seu } \\
\text { atendimento? }\end{array}$} & 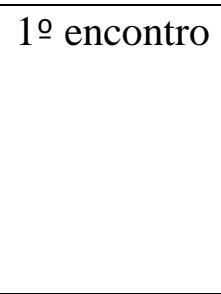 & $\begin{array}{l}\text { Balcão de atendimento } \\
(0) \text {, teste rápido (1), } \\
\text { acolhimento }(2) \text {, } \\
\text { consulta com o médico } \\
\text { (4), para pegar os } \\
\text { medicamentos (5) }\end{array}$ \\
\hline & 20 encontro & 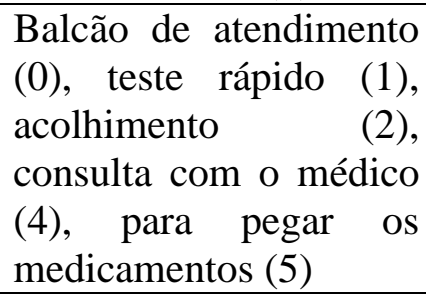 \\
\hline & 3 o encontro & 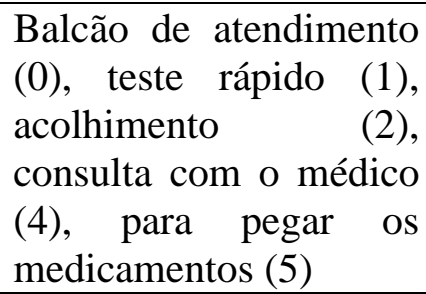 \\
\hline \multirow{6}{*}{$\begin{array}{l}\text { 67. O serviço de saúde atendeu a suas } \\
\text { necessidades? }\end{array}$} & \multirow[t]{2}{*}{1 ㅇ encontro } & Sim (1) Por quê? \\
\hline & & Não (2) Por quê? \\
\hline & \multirow[t]{2}{*}{20 encontro } & Sim (1) Por quê? \\
\hline & & Não (2) Por quê? \\
\hline & \multirow[t]{2}{*}{30 encontro } & Sim (1) Por quê? \\
\hline & & Não (2) Por quê? \\
\hline \multirow{2}{*}{$\begin{array}{l}\text { 68. Você teve oportunidade para esclarecer } \\
\text { dúvidas? }\end{array}$} & \multicolumn{2}{|l|}{$\operatorname{Sim}(1)$} \\
\hline & Não (0) & Por quê? \\
\hline
\end{tabular}




\section{APÊNDICE 2 \\ TERMO DE CONSENTIMENTO LIVRE E ESCLARECIDO}

\section{UNIVERSIDADE DE SÃO PAULO ESCOLA DE ENFERMAGEM DA USP}

Departamento de Enfermagem em Saúde Coletiva. Av. Dr. Enéas de Carvalho Aguiar, 419, 2o andar - Cerqueira César - São Paulo/SP - CEP 05403-000 - e-mail: enssecre @ usp.br Telefones: (11) 3061-7652 - Fax: (11)3061-7662

Termo de Consentimento Livre e Esclarecido

Pesquisa: Adesão à profilaxia pós-exposição sexual consentida ao HIV

Meu nome é Marcos Morais Santos Silva, sou enfermeiro e aluno de mestrado em Saúde Coletiva da Escola de Enfermagem da Universidade de São Paulo. Estou convidando você para participar de forma voluntária e não remunerada da pesquisa: FATORES QUE INTERFEREM NA ADESÃO À PROFILAXIA PÓS-EXPOSIÇÃO AO HIV (PEP), desenvolvida pelo pesquisador Marcos Morais Santos Silva sob orientação da Profa. Dra. Lucia Yazuko Izumi Nichiata. Este estudo justifica-se pela baixa produção científica sobre a adesão aos medicamentos da profilaxia pós-exposição ao HIV e tem a finalidade de oferecer evidências sobre a importância da adesão como elemento-chave para a diminuição da transmissão do HIV. Esta pesquisa tem o objetivo de analisar a adesão à profilaxia pósexposição sexual consentida ao HIV em usuários de um serviço de atenção especializada em HIV/Aids no município de São Paulo.

Solicito sua colaboração para responder a algumas perguntas sobre você e o serviço de saúde em cada retorno que você fizer, realizadas em um local reservado no centro de referência ou em outro local de sua preferência, ou por telefone, caso você não compareça em algum dos retornos e autorize contato.

No primeiro retorno, o tempo para responder aos questionários, tanto presencialmente como por telefone, será de aproximadamente 20 minutos. No segundo retorno, o tempo para as respostas, presencialmente ou por telefone, será de aproximadamente 5 minutos.

Peço, também, sua autorização para acessar seu prontuário e obter informações sobre você através do questionário aplicado pelo profissional do serviço de saúde durante o seu acolhimento na primeira consulta, além das informações dos seus testes rápidos realizados durante os acompanhamentos.

O risco desta entrevista é o emocional, pois você pode se sentir constrangido e desconfortável nela. Caso isso ocorra, a entrevista poderá ser interrompida e me comprometo a acolhê-lo(a) e providenciar, se necessário, encaminhamento para um serviço de saúde. Se alguma pergunta do questionário lhe causar desconforto emocional ou constrangimento, você poderá recusar-se a respondê-la.

A sua participação nesta pesquisa poderá trazer benefícios indiretos aos usuários do serviço de saúde, pois, uma vez que se identifique como ocorre a adesão aos medicamentos, quem são as pessoas que aderem e não aderem à profilaxia pós-exposição ao HIV e quais as necessidades dos usuários do serviço de saúde diante dessa problemática, é possível aplicar medidas na tentativa de se obter uma diminuição da infecção ao HIV.

Sua participação é voluntária e você pode retirar seu consentimento ou desistir de participar desta pesquisa em qualquer momento. A sua recusa não irá acarretar qualquer penalidade ou perda do seu acompanhamento no serviço de saúde. 
A sua identidade será tratada com os devidos padrões profissionais de sigilo pelo pesquisador em todas as fases da pesquisa. Os dados coletados serão utilizados somente para a pesquisa, e os resultados poderão ser veiculados por meio de artigos científicos em revistas especializadas e/ou eventos científicos, sempre resguardando sua identidade. Você não será identificado(a) em nenhuma publicação que venha a surgir com esse estudo.

Este Termo de Consentimento Livre e Esclarecido serve para comprovar que você está de acordo em participar da pesquisa. Você deverá rubricar todas as páginas, assinar as duas vias e ficar com uma. A via que ficar com você também será assinada e rubricada pelo pesquisador.

A participação na pesquisa não acarretará custos para você, mas, caso tenha alguma despesa durante o processo, o valor será ressarcido pelo pesquisador. E, caso ocorram eventuais danos decorrentes da sua participação na pesquisa, você será indenizado(a).

Em qualquer etapa da pesquisa, você terá acesso aos pesquisadores responsáveis para esclarecimento de dúvidas. O principal pesquisador responsável é a Profa. Dra. Lucia Yasuko Izumi Nichiata, que pode ser encontrada no endereço: Av. Dr. Enéas de Carvalho Aguiar, 419, Cerqueira César, CEP 05403-000 - São Paulo/SP, pelo telefone (11) 3061-7652 e pelo e-mail: izumi@usp.br, ou Marcos Morais Santos Silva, que pode ser encontrado no endereço: Rua Hermes Fonseca, 12, Vila Schunck, CEP 06900-000 - Embu-Guaçu/SP, pelo telefone (11)99788-5724 e pelo e-mail: marcosmoss30@ gmail.com.

Se você tiver alguma dúvida ou consideração sobre a ética desta pesquisa, a qualquer momento entre em contato com o Comitê de Ética em Pesquisa (CEP) da Escola de Enfermagem da USP, Av. Dr. Enéas de Carvalho Aguiar, 419, Cerqueira César, CEP 05403000 - São Paulo/SP, telefone (11) 3061-8858 e e-mail: cepee@usp.br, ou com o coparticipante: Comitê de Ética em Pesquisa da Secretaria Municipal da Saúde (CEP/SMS), Rua General Jardim, 36 - 8o andar. Informações/dúvidas pelo telefone (11) 3397-2464 ou pelo e-mail smscep@gmail.com. Horário de atendimento: de segunda a sexta, das $10 \mathrm{~h}$ às $13 \mathrm{~h}$ e das $14 \mathrm{~h}$ às $17 \mathrm{~h}$.

Esta pesquisa atende a todas as especificações da Resolução 466, de 12 de dezembro de 2012, que aprova as diretrizes e normas regulamentadoras de pesquisas envolvendo seres humanos.

Assinatura do pesquisador

Assinatura do participante

São Paulo, de de 2019. 
ANEXOS 
ANEXO 1

\section{QUESTIONÁRIO SI-DST AIDS-MÓDULO DE DIAGNÓSTICO SOROLÓGICO}

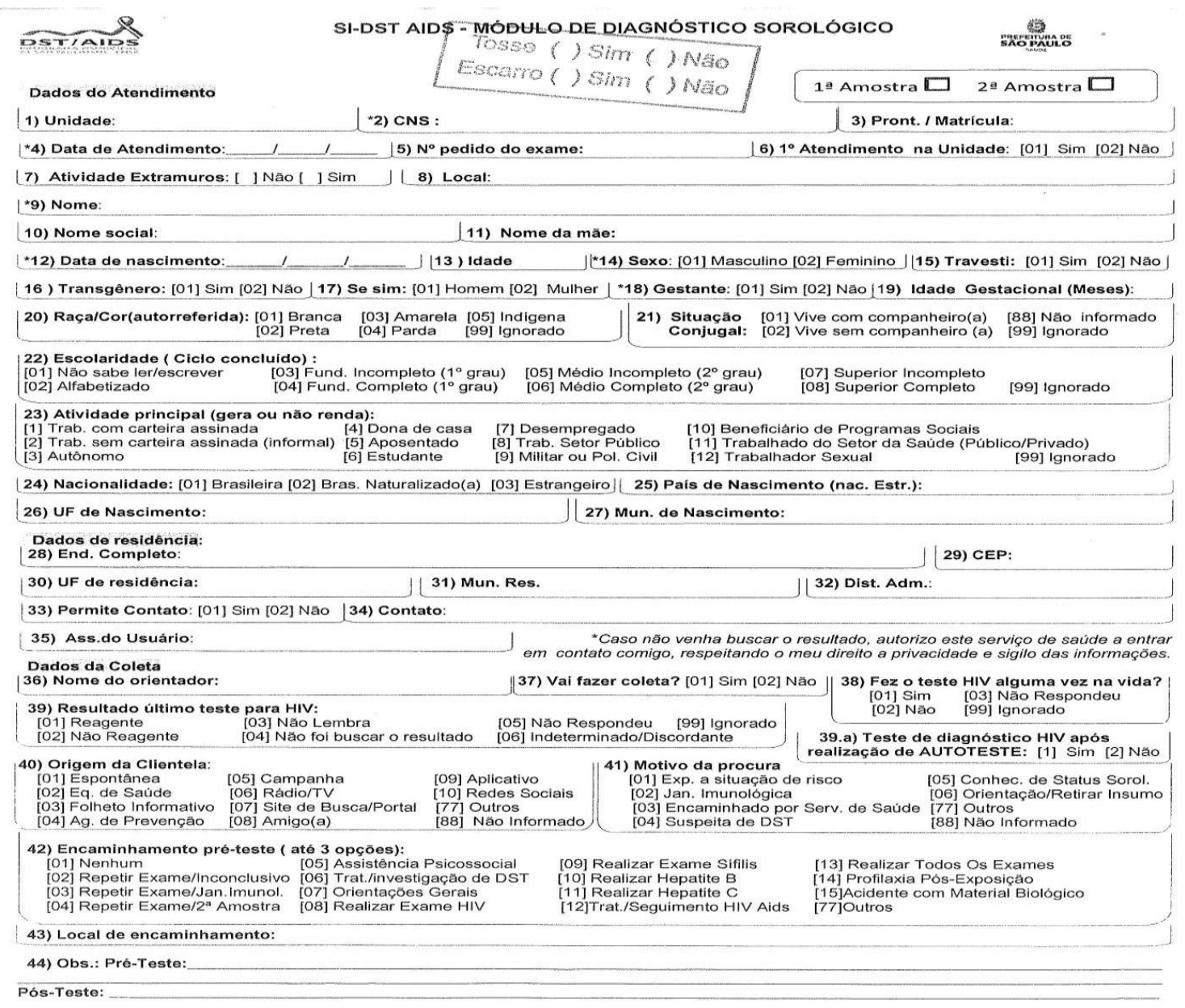




\section{ANEXO 1 (continuação)}

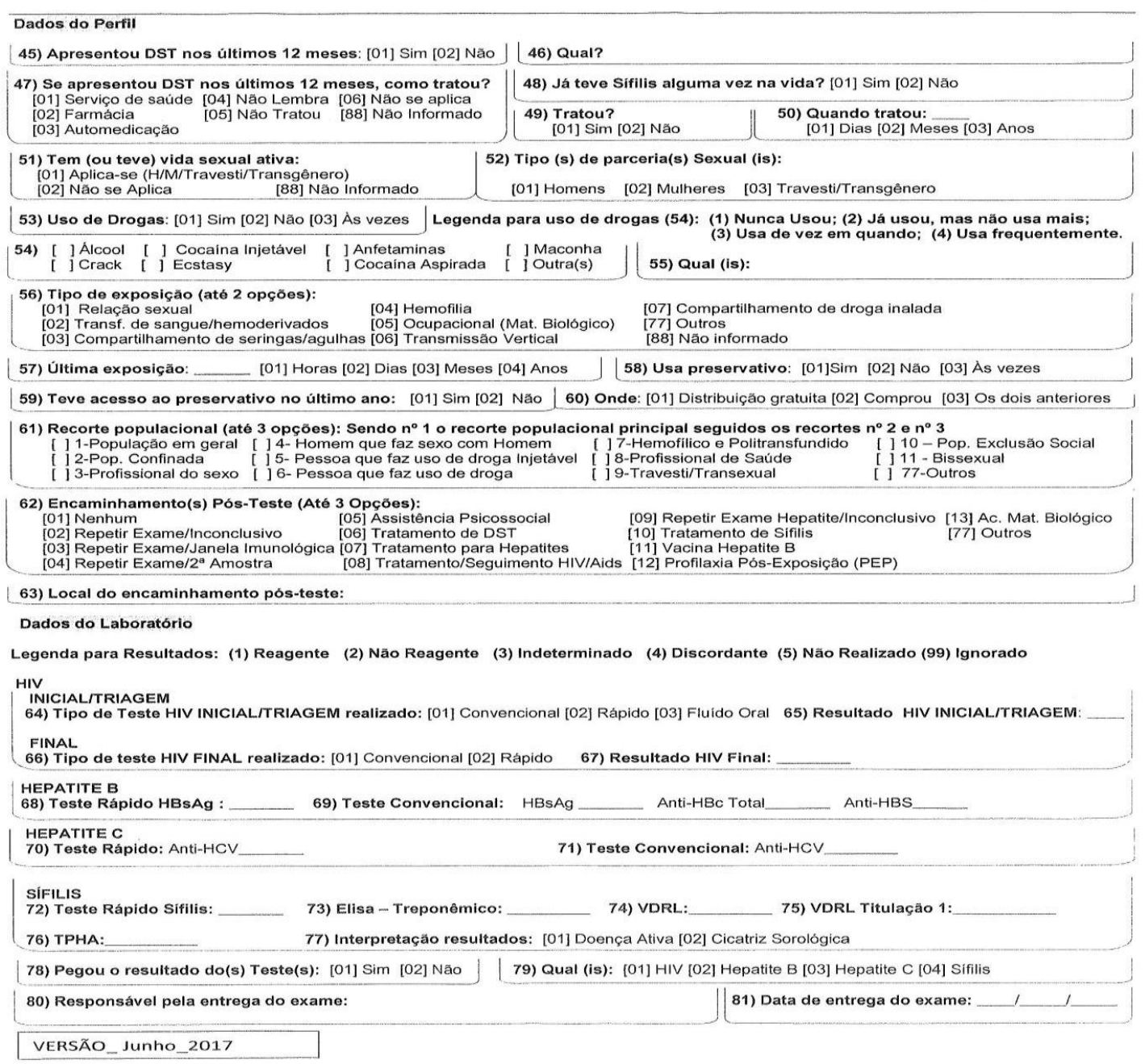




\section{ANEXO 2}

\section{QUESTIONÁRIO PARA A AVALIAÇÃO DA ADESÃO AO TRATAMENTO ANTIRETROVIRAL (CEAT-VIH, VERSÃO EM PORTUGUÊS [BRASIL]).}

\footnotetext{
Durante a última semana
}

1. Deixou de tomar sua medicação alguma vez? 2. Se alguma vez sentiu-se melhor, deixou de tomar sua medicação?

3. Se alguma vez depois de tomar sua medicação sentiu-se pior, deixou de tomá-la?

4. Se alguma vez se sentiu triste ou deprimido, deixou de tomar sua medicação?

\begin{tabular}{|l|l|l|l|l|}
\hline Sempre & $\begin{array}{c}\text { Mais da metade } \\
\text { das vezes }\end{array}$ & $\begin{array}{c}\text { Aproximadamente } \\
\text { a metade das vezes }\end{array}$ & $\begin{array}{c}\text { Alguma } \\
\text { vez }\end{array}$ & $\begin{array}{c}\text { Nenhuma } \\
\text { vez }\end{array}$ \\
\hline & & & & \\
\hline & & & & \\
\hline & & & & \\
\hline & & & & \\
\hline
\end{tabular}

5. Lembra-se que remédios está tomando nesse momento? (escrever os nomes) 6. Como é a relação que mantém com o seu médico? \begin{tabular}{l|l|l} 
Ruim & Um pouco ruim & Regular
\end{tabular}

\begin{tabular}{|c|c|}
\hline Pode melhorar & Boa \\
\hline
\end{tabular}

7. Quanto você se esforça para seguir com o tratamento?

8. Quanta informação você tem sobre os medicamentos que toma para o HIV?

9. Quanto benefício pode the trazer o uso destes medicamentos?

10. Considera que sua saúde melhorou desde que comecou a tomar os medicamentos para o HIV?

11. Até que ponto sente-se capaz de seguir com o tratamento?

\begin{tabular}{|l|l|l|l|l|}
\hline Nada & Pouco & Regular & Bastante & Muito \\
\hline & & & & \\
\hline & & & & \\
\hline & & & & \\
\hline & & & & \\
\hline & & & & \\
\hline
\end{tabular}

12. Normalmente está acostumado a tomar a medicação na hora certa?

13. Quando os resultados dos exames são bons, seu médico costuma utilizá-los para lhe dar ânimo e motivação para seguir com o tuma utiliza-los para lhe dar ânimo e motivação para seguir com o tratamento?

\begin{tabular}{|c|c|c|c|c|}
\hline $\begin{array}{c}\text { Não, } \\
\text { nunca }\end{array}$ & $\begin{array}{c}\text { Sim, } \\
\text { alguma } \\
\text { vez }\end{array}$ & $\begin{array}{c}\text { Sim, aproximada- } \\
\text { mente a metade } \\
\text { das vezes }\end{array}$ & $\begin{array}{c}\text { Sim, } \\
\text { muitas } \\
\text { vezes }\end{array}$ & $\begin{array}{c}\text { Sim, } \\
\text { sempre }\end{array}$ \\
\hline & & & & \\
\hline & & & & \\
\hline
\end{tabular}

14. Como sente-se em geral com o tratamento desde que começou a tomar seus remédios?

\begin{tabular}{|c|c|c|c|c|}
\hline Muito insatisfeito & Insatisfeito & Indiferente & Satisfeito & Muito satisfeito \\
\hline
\end{tabular}

15. Como avalia a intensidade dos efeitos colaterais relacionados com o uso dos medicamentos para o HIV?

\begin{tabular}{|c|c|c|c|c|}
\hline Muito intensos & Intensos & Medianamente intensos & Pouco intensos & Nada intensos \\
\hline \multicolumn{5}{|c|}{ 16. Quanto tempo acredita que perde ocupando-se em tomar seus remédios? } \\
\hline Muito tempo & Bastante tempo & Regular & Pouco tempo & Nada de tempo \\
\hline Nada cumpridor & Pouco cumpridor & \begin{tabular}{|c|} 
Regular \\
\end{tabular} & Bastante & Muito cumpridor \\
\hline Muita dificuldade & Bastante dificuldade & Regular & Pouca dificuldade & Nenhuma dificuldade \\
\hline
\end{tabular}

19. Desde que está em tratamento alguma vez deixou de tomar sua medicação um dia completo, ou mais de um? [Se responde afirmativamente, Quantos dias aproximadamente?]

20. Utiliza alguma estratégia para lembrar-se de tomar a medicação?

\begin{tabular}{|l|l|}
\hline SIM & NÃO \\
\hline & \\
\hline & \\
\hline
\end{tabular}


ANEXO 3

\section{APROVAÇÃO DO COMITÊ DE ÉTICA EM PESQUISA DA ESCOLA DE ENFERMAGEM DA UNIVERSIDADE DE SÃO PAULO}

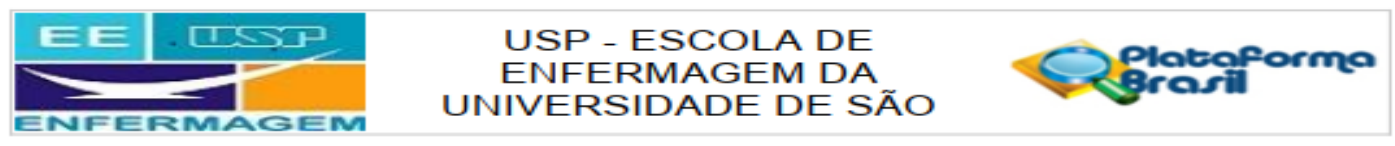

\section{PARECER CONSUBSTANCIADO DO CEP}

DADOS DO PROJETO DE PESQUISA

Título da Pesquisa: Adesão a profilaxia pós-exposição sexual consentida ao HIV Pesquisador: MARCOS MORAIS SANTOS SILVA

Área Temática:

Versão: 1

CAAE: 06245519.6.0000.5392

Instituição Proponente: Escola de Enfermagem da Universidade de São Paulo - EEUSP

Patrocinador Principal: Financiamento Próprio

DADOS DO PARECER

Número do Parecer: 3.167.045

Apresentação do Projeto:

Trata-se de projeto de mestrado que tem por objeto de estudo a Profilaxia Pós Exposição ao HIV (PEP), enquanto uma das diretrizes internacionais recomendadas como medida de prevenção contra a epidemia do HIV. Esta consiste do uso oral de

antirretrovirais durante 28 dias, iniciados em até 72 horas após a exposição.

Objetivo da Pesquisa:

Analisar a adesão a PEP devido exposição sexual

consentida ao HIV em usuários de um serviço de atenção especializada HIVIAIDS do

municipio de São Paulo

Avaliação dos Riscos e Benefícios:

Não apresenta Avaliação de riscos e benefícios no projeto

Comentários e Considerações sobre a Pesquisa:

O projeto é relevante do ponto de vista de saúde publica e para a população que se expõe ao HIV. Ademais, justifica-se pela baixa produção científica sobre a adesão aos medicamentos da Profilaxia PósExposição. Concluido, poderá oferecer evidências sobre a importância da adesão como elemento chave para diminuição da transmissão do HIV

Considerações sobre os Termos de apresentação obrigatória:

O cronograma está dentro do prazo possível de análise ética do projeto. Há garantia de privacidade durante a coleta de dados. O TCLE está Adequado as especificações da Resolução

Endereço: Av. Dr. Enéas de Carvalho Aguiar. 418

Endereço: Av. Dr. Enéas de Carvalho Aguiar, 419 CEP: 05.403-000
Bairro: Cerqueira Cesar

UF: SP Municipio: SAO PAULO

Telefone: (11)3061-8858

E-mail: cepee@usp.br 


\section{ANEXO 3 (continuação)}

\begin{tabular}{|c|c|c|c|} 
USP - ESCOLA DE \\
ENFERMAGEM DA \\
UNIVERSIDADE DE SÃO
\end{tabular}

Contlnuaçă๋ do Parecer: 3.167 .045

$466 / 12$

Recomendações:

Acrescentar Riscos e Benefícios no projeto

Conclusões ou Pendências e Lista de Inadequações:

Não há.

Considerações Finais a critério do CEP:

Aguarda-se as respostas às pendências assinaladas num prazo máximo de 30 dias, após esse período o processo será arquivado. Favor salientar as modificações realizadas nos documentos, para que os mesmos não tenham que ser lidos na íntegra novamente.

Este parecer foi elaborado baseado nos documentos abaixo relacionados:

\begin{tabular}{|c|c|c|c|c|}
\hline Tipo Documento & Arquivo & Postagem & Autor & Situação \\
\hline $\begin{array}{l}\text { Informações Básicas } \\
\text { do Projeto }\end{array}$ & $\begin{array}{l}\text { PB_INFORMAÇOEES_BÁSICAS_DO_P } \\
\text { ROJETO 1265618.pdf }\end{array}$ & $\begin{array}{c}24 / 01 / 2019 \\
13: 47: 02\end{array}$ & & Aceito \\
\hline Outros & cartaaut_pdf & $\begin{array}{c}24 / 01 / 2019 \\
11: 56: 42\end{array}$ & $\begin{array}{l}\text { MARCOS MORAIS } \\
\text { SANTOS SILVA }\end{array}$ & Aceito \\
\hline Outros & carta_autorizacao.pdf & $\begin{array}{c}24 / 01 / 2019 \\
11: 49: 54\end{array}$ & $\begin{array}{l}\text { MARCOS MORAIS } \\
\text { SANTOS SILVA }\end{array}$ & Aceito \\
\hline $\begin{array}{l}\text { TCLE / Termos de } \\
\text { Assentimento / } \\
\text { Justificativa de } \\
\text { Ausência }\end{array}$ & termo_consentimento.pdf & $\begin{array}{c}24 / 01 / 2019 \\
11: 45: 58\end{array}$ & $\begin{array}{l}\text { MARCOS MORAIS } \\
\text { SANTOS SILVA }\end{array}$ & Aceito \\
\hline Cronograma & cronograma_PEP.pdf & $\begin{array}{c}24 / 01 / 2019 \\
11: 15: 33\end{array}$ & $\begin{array}{l}\text { MARCOS MORAIS } \\
\text { SANTOS SILVA } \\
\end{array}$ & Aceito \\
\hline $\begin{array}{l}\text { Projeto Detalhado / } \\
\text { Brochura } \\
\text { Investigador }\end{array}$ & projeto_PEP.pdf & $\begin{array}{c}24 / 01 / 2019 \\
11: 14: 49\end{array}$ & $\begin{array}{l}\text { MARCOS MORAIS } \\
\text { SANTOS SILVA }\end{array}$ & Aceito \\
\hline Folha de Rosto & folha_de_rosto.pdf & $\begin{array}{c}24 / 01 / 2019 \\
11: 02: 19\end{array}$ & $\begin{array}{l}\text { MARCOS MORAIS } \\
\text { SANTOS SILVA }\end{array}$ & Aceito \\
\hline
\end{tabular}

Situação do Parecer:

Aprovado

Necessita Apreciação da CONEP:

Não

Endereço: Av. Dr. Enéas de Carvalho Aguiar, 419 CEP: $05.403-000$
Bairro: Cerqueira Cesar
$\begin{aligned} & \text { UF: SP } \\ & \text { Telefone: (11)3061-8858 }\end{aligned}$ 


\section{ANEXO 3 (continuação)}

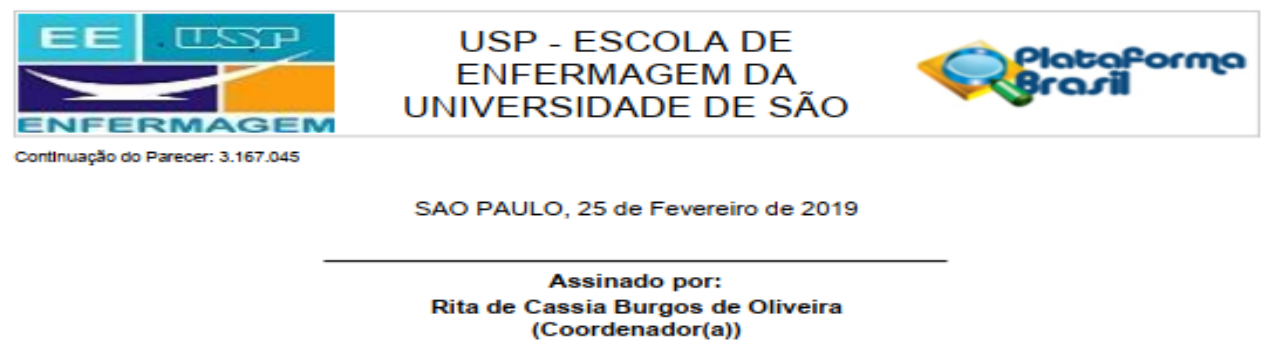

Endereço: Av. Dr. Enéas de Carvalho Aguiar, 419 CEP: $05.403-000$
Bairro: Cerqueira Cesar

UF: SP Município: SAO PAULO

Telefone: (11)3061-8858

E-mail: cepee@usp.br 
ANEXO 4

\section{APROVAÇÃO DO COMITÊ DE ÉTICA EM PESQUISA DA SECRETARIA DE SAÚDE DO MUNICÍPIO DE SÃO PAULO}

EM PESQUISA-SMS
SACOUDE DE SÃO PAULO -
SMSISP

\section{PARECER CONSUBSTANCIADO DO CEP}

Elaborado pela Instituição Coparticipante

\section{DADOS DO PROJETO DE PESQUISA}

Título da Pesquisa: Adesão a profilaxia pós-exposição sexual consentida ao HIV Pesquisador: MARCOS MORAIS SANTOS SILVA

Área Temática:

Versão: 1

CAAE: 06245519.6 .3001 .0086

Instituição Proponente: SECRETARIA MUNICIPAL DA SAUDE

Patrocinador Principal: Financiamento Próprio

\section{DADOS DO PARECER}

Número do Parecer: 3.180 .010

Apresentação do Projeto:

Tratar-se-á de um estudo de abordagem quantitativa, descritivo e analítico para Analisar a adesão a PEP Profilaxia Pós Exposição ao HIV, devido à exposição sexual consentida ao HIV em usuários de um serviço de atenção especializada HIVIAIDS do municipio de São Paulo. Existem apontamentos que indicam uma crise na prevenção; uma vez que o aumento da expectativa de vida em pessoas vivendo com HIV não foi acompanhado pela redução de novos casos de infecção nos grupos vulneráveis à doença (UNAIDS, 2018), implicando na importância de direcionar os investimentos em métodos educativos e na realização de pesquisas que visem às melhores formas de enfrentamento da epidemia com enfoque em medidas de prevenção.

Não basta que o usuário do serviço de saúde queira tomar os medicamentos, é preciso entender que a adesão depende de diversos fatores que estão ao redor da vida do indivíduo (Bertolozzi, 2009). Assim, ter um usuário do serviço de saúde "vinculado e aderido" às recomendações é um desafio; também é preciso destacar a importância de alcançar todos os grupos populacionais, uma vez que a dificuldade de acesso tende a afetar os mais vulneráveis, como mulheres profissionais do sexo (Izulla, 2013), deixando-os mais expostos à infecção pelo HIV.

Após assinatura do Termo de Consentimento Livre e Esclarecido pelos usuários do serviço de saúde, serão acessados os prontuários para recolher informações do questionário aplicado pelo profissional de saúde do SAE HIVIAIDS, intitulado SI-DST AIDS-Módulo de

diagnóstico sorológico. Esse questionário (Anexo 1) é composto por 81 questões distribuídas em

Endereço: Rua General Jardim, $36-8^{\circ}$ andar
$\begin{aligned} & \text { Bairro: Vila Buarque } \\ & \text { UF: SP }\end{aligned} \quad$ Município: SAO PAULO
$\begin{aligned} & \text { Telefone: } \\ & \text { (11)3397-2464 }\end{aligned} \quad$ E-mail: smscep@grmail.com




\section{ANEXO 4 (continuação)}

SECRETARIA MUNICIPAL DA
EM PESQUISA-SMS

Contınuaçăo do Parecer: 3.180 .010

cinco bloco de dados: socioeconômico (questões de 20 a 23), atendimento (questões de 1 a 27), residência (questões de 28 a 35), coleta (questões de 36 a 44), perfil (questões de 45 a 63) e de laboratório (questões de 63 a 81). Este é o primeiro questionário a ser utilizado na pesquisa.

Será aplicado um segundo questionário, elaborado pelo pesquisador sobre a adesão a PEP por exposição sexual consentida ao HIV e sobre a assistência prestada ao usuário pelo SAE HIVIAIDS. Este questionário será aplicado no primeiro retorno ( 30 dias após a consulta inicial) e é composto por 20 questões fechadas e abertas (Apêndice 1). As questões foram elaboradas com base na literatura "Cuestionario para la Evaluación de la Adhesión al Tratamiento Antirretroviral" - CEAT-VIH (Remor et al, 2007); Validation of a simplified medica- tion adherence questionnaire in a large cohort of HIV-infected patients (Knobel et al, 2002). A questão de número 20 deste questionário (Apêndice 1), sobre exposição ao HIV nos últimos 30 dias, será aplicada em dois momentos, primeiro e segundo retorno.

Este questionário também será aplicado para os usuários que não comparecerem no primeiro retorno, por meio de contato telefônico, com duração de aproximadamente 20 minutos, além de mais uma questão para conhecer os motivos da ausência ao serviço de saúde (Apêndice 2). No segundo e último retorno (60 dias após a consulta inicial), o usuário será questionado novamente sobre a exposição sexual nos últimos 30 dias (Apêndice 1);

os que não retornarem também serão questionados sobre exposição sexual nos últimos 30 dias (Apêndice 1) e sobre o motivo da ausência ao serviço de saúde, por meio de ligação telefônica (Apêndice 2).

\section{Objetivo da Pesquisa:}

Objetivo Primário: Analisar a adesão a PEP devido exposição sexual consentida ao HIV em usuários de um SAE HIVIAIDS do município de São Paulo.

Objetivo Secundário: •Caracterizar os usuários indicados para PEP devido exposição sexual consentida ao HIV em um SAE HIVIAIDS; •Verificar a adesão a PEP devido exposição sexual consentida ao HIV em usuários do SAE HIVIAIDS; •Avaliar fatores condicionantes presentes na adesão à PEP referidos às condições sociodemográficas, inserção do indivíduo na sociedade e condições da assistência do SAE HIVIAIDS.

Avaliação dos Riscos e Benefícios:

Riscos: O risco para o usuário do serviço de saúde é o emocional, pois ele pode se sentir constrangido e desconfortável durante a entrevista.

Endereço: Rua General Jardim, 36 - $8^{\circ}$ andar

Bairro: Vila Buarque

UF: SP Município: SAO PAULO

Telefone: (11)3397-2464

CEP: $01.223-010$

E-mail: smscep@gmail.com 


\section{ANEXO 4 (continuação)}

SECRETARIA MUNICIPAL DA
SAÚDE DE SÃO PAULO -
SMSISP

Contlnuaçăo do Parecer: 3.180 .010

Benefícios: A pesquisa poderá trazer benefícios indiretos aos usuários do serviço de saúde, pois uma vez identificado como ocorre à adesão aos medicamentos, quem são as pessoas que aderem e não adere a Profilaxia Pós Exposição ao HIV e quais as necessidades dos usuários do serviço de saúde frente a essa problemática, é possivel aplica-los, na tentativa de se obter uma diminuição da infecção ao HIV.

\section{Comentários e Considerações sobre a Pesquisa:}

O projeto de pesquisa é extremamente relevante, muito claro na sua execução, com metodologia adequada e objetivos bem definidos.

Considerações sobre os Termos de apresentação obrigatória:

A Folha de Rosto está adequada, foi identificada instituição proponente e apresentada autorização da Coordenadoria Geral da Saúde Centro da Secretaria Municipal de Saúde de São Paulo como coparticipante. O cronograma está adequado.

$O$ orçamento e fonte financiadora estão ok.

O TCLE adequado.

Recomendações:

Conclusões ou Pendências e Lista de Inadequações:

Sem pendências ou inadequações.

Considerações Finais a critério do CEP:

Para início da coleta dos dados, o pesquisador deverá se apresentar na mesma instância que autorizou a realização do estudo (Coordenadoria, Supervisão, SMS/Gab, etc).

Salientamos que o pesquisador deve desenvolver a pesquisa conforme delineada no protocolo aprovado. Eventuais modificações ou emendas ao protocolo devem ser apresentadas ao CEP de forma clara e sucinta, identificando a parte do protocolo a ser modificada e suas justificativas. Lembramos que esta modificação necessitará de aprovação ética do CEP antes de ser implementada.

De acordo com a Res. CNS 466/12, o pesquisador deve apresentar os relatórios parciais e final através da Plataforma Brasil, icone Notificação. Uma cópia digital (CD/DVD) do projeto finalizado

Endereço: Rua General Jardim, $36-8^{\circ}$ andar Bairro: Vila Buarque

UF: SP Município: SAO PAULO

Telefone: (11)3397-2484

CEP: $01.223-010$

E-mail: smscep@gmail.com 


\section{ANEXO 4 (continuação)}

$\underset{\text { EM PESQUISA-SMS }}{0} \begin{gathered}\text { SECRETARIA MUNICIPAL DA } \\ \text { SAÚDE DE SÃO PAULO - } \\ \text { SMS/SP }\end{gathered}$

Contınuạ̧ăo do Parecer: 3.180 .010

deverá ser enviada à instância que autorizou a realização do estudo, via correio ou entregue pessoalmente, logo que o mesmo estiver concluido.

Este parecer foi elaborado baseado nos documentos abaixo relacionados:

\begin{tabular}{|l|l|c|l|c|}
\hline \multicolumn{1}{|c|}{ Tipo Documento } & \multicolumn{1}{|c|}{ Arquivo } & Postagem & \multicolumn{1}{c|}{ Autor } & Situação \\
\hline Outros & cartaaut.pdf & $\begin{array}{c}24 / 01 / 2019 \\
11: 56: 42\end{array}$ & $\begin{array}{l}\text { MARCOS MORAIS } \\
\text { SANTOS SILVA }\end{array}$ & Aceito \\
\hline Outros & carta_autorizacao.pdf & $\begin{array}{c}24 / 01 / 2019 \\
11: 49: 54\end{array}$ & $\begin{array}{l}\text { MARCOS MORAIS } \\
\text { SANTOS SILVA }\end{array}$ & Aceito \\
\hline $\begin{array}{l}\text { TCLE / Termos de } \\
\text { Assentimento / } \\
\text { Justificativa de } \\
\text { Ausência }\end{array}$ & termo_consentimento.pdf & $24 / 01 / 2019$ & $\begin{array}{l}\text { MARCOS MORAIS } \\
\text { SANTOS SILVA }\end{array}$ & Aceito \\
\hline $\begin{array}{l}\text { Projeto Detalhado / } \\
\text { Brochura } \\
\text { Investigador }\end{array}$ & projeto_PEP.pdf & $11: 45: 58$ & & \\
\hline
\end{tabular}

Situação do Parecer:

Aprovado

Necessita Apreciação da CONEP:

Não

SAO PAULO, 01 de Março de 2019

Assinado por:

SIMONE MONGELLI DE FANTIN

(Coordenador(a)) 